\title{
PERFORMANCE CONTROL STRATEGIES FOR OIL-FIRED RESIDENTIAL HEATING SYSTEMS
}

PROJECT REPORT

\author{
T. Butcher
}

BNL- -52250

DE91 001095

\author{
July 1990
}

\author{
Prepared for the \\ BUILDING EQUIPMENT DIVISION \\ OFFICE OF BUILDING TECHNOLOGIES \\ UNITED STATES DEPARTMENT OF ENERGY
}

\author{
DEPARTMENT OF APPLIED SCIENCE \\ BROOKHAVEN NATIONAL LABORATORY \\ ASSOCIATED UNIVERSITIES, INC.
}

Under Contract No. DE-ACO2-76CH00016 with the UNITED STATES DEPARTMENT OF ENERGY 


\section{IISCLAIMEK}

This report was prepared as an account of work sponsored by an agency of the United States Government. Neither the United States Government ner any agency thereof, nor ar,y of their employees, nor any of their contractors, subcontractors, or their employees, makes any warranty, exprese or implied, or assumes any legal liability or respotisibility for the accuracy, completeness, or usefulness of any information, appars:tus, product, or procese disclesed, or represents that its use would not infringe privately owned rights. Reference herein to any specific commercial product, process, or service by tade name, trademark, manufacturer, or otherwise, does not necesaturily constitute or imply itsendorement, recommendation, or favoring hy the lnited States Government or any asencey, contractor or subeontractor thareese. The views and opinions of authors expressed herein do not necessarily stute or reflect these of the United states Government or any agency, contractor or subeontractor therend.

Printed in the United States of America

Available from

National Technichl Information Service

U.S. Department of (ommerce

5285 Port Royal Roud

Springfield, VA2216!

N'Tls price codes:

Printed Copy: Allf; Microfiche (opy: Aoll 


\section{ABSTRACT}

Results are reported of a study of control system options which can be used to improve the combustion performance of residential, oil-fired heating equipment. Two basic control modes were considered in this program. The first is "service required" signals in which an indication is provided when the flame quality or heat exchanger cleanliness have degraded to the point that a service call is required. The second control mode is "excess-air trim" in which the burner would essentially tune itself cuntinuously for maximum efficiency.

A key ingredient in any practical control system for this application is reliable, low-cost sensors and the identification of such sensors has been a primary emphasis of this project. An overview of current sensors used in commercial/industrial boilers and princlples of operation is included.

To identify useful measurements, specific parametric studies related to control strategies were performed. These included:

a) relationships between flue gas $\mathrm{CO}$, smoke, and excess air with selected burners

b) effects of excess air level, ambient air temperature, boiler water temperature, firing time, and furnace air flow rate on flue gas temperature.

It was found that evaluation of the rate of performance degradation due to heat exchanger fouling can be done very simply using the peak flue gas temperature during heating season firing cycles. Also, CO was not found to be a useful indication of flame quality.

Tests were performed with low cost, automotive type zirconium oxide oxygen sensors. This included units with and without integral electric heating elements. The unheated sensors were installed in the wall of the refractory combustion chamber liner where the steady state temperature was within the proper range for sensor operation. This provided a useful signal related to excess air but unacceptably slow response in cyclic operation. The heated oxygen senor was installed in the flue and performed well. A small commercial oxygen analyzer system, also using a zirconium oxide sensor, was also found to work well in the flue.

Sensors based on measuring light emission from the flame were identified as a potentially very low cost approach to evaluating flame quality. Detailed spectral emission studies were done over the range 200-1100 nm (ultraviolet [UV] to near infrared [IR]) with conventional pressure atomized burners and one air atomized burner. Useful measures of flame quality include flame brightness, color, and brightness normalized to the $\mathrm{OH}$ spectral peak in the UV. A simple, three light flame quality indicator was developed using a photoresistor for input. This low cost system is shown to be very useful for monitoring changes in flame quality between service calls. Costs, and potential benefits of this and other control strategies, including active excess air trim are reviewed. 


\section{SUMMARY}

\section{Introduction}

The goal of the work rescribed in this report is to develop recommendations for control strategies which can be used to raise the efficiency of oil fired heating equipment in service.

The adjusted efficiency of oil-fired domestic heating systems in the home is lower than can be achieved with the same equipment under ideal conditions. Two factors are responsible. First, when burners are serviced excess air is set higher than necessary. This is done in the hope that it will prevent future sooting problems. Also, service personnel often do not use the instrumentation required to set the excess air properly. The second factor is fouling of heat exchanger surfaces over time with products of incomplete combustion, acids and corrosion products.

Two basic control modes can be considered for maintaining high efficiency operation:

- Service-required signals - in this mode the homeowners or service company would be made aware that smoke production and/or efficiency have degraded to the point that service is required.

- Steady-state excess-air trim - in this mode the burner would essentially tune itself continuously for maximum efficiency. Excess air would be changed in response to changes in fuel quality, draft, nozzle erosion, etc. to maintain "trace" smoke in steady state.

In implementing these control strategies an input is required which is related to air/fuel ratio and/or flame quality. This type of input could alternatively be used as a service tool. Instead of making excess air and smoke number measurements at a series of points and then selecting a setpoint, the excess air could simply be adjusted until a predetermined control signal is reached. The development of sensor inputs for advariced service tools, while not truly a "control" was considered as a part of the goals of this profect.

Estimates of the magnitude of the annual degradation in thermal efficiency based on earlier published studies show considerable variation between units. The average is roughly 2 per year. Principle causes of deterioration are seen as fouling of the heat exchanger surfaces by soot, fouling of the oil nozzle, and changes in air/fuel ratio calused by dust accumulation on the air inlets. Sooting appears to be the key degradation process.

Generally, the introduction of advanced control systems could potentially reduce fuel consumption due to both high excess air and heat exchanger fouling.

\section{Background}

A wide variety of systems which control air/fuel ratio are commonly used on commercial and light industrial boilers. Current practice and experience in this area provide a base for considering such systems on a residential scale. 
Boilers in this category are typically fully modulating and the control systems function to vary the air/fuel ratio over the load range, increasing excess air as firing rate decreases to avoid smoke. Control systems vary widely and can be roughly categorized with increasing complexity as follows:

1. Preset air/fuel ratio profile

2. Feed forward $-\mathrm{O}_{2}$ trim

3. $\mathrm{O}_{2}$ feedback

4. $\mathrm{O}_{2}$ and $\mathrm{CO}$ feedback

A common component in commercial and industrial boiler control systems is the zirconium oxide oxygen sensor. This rugged sensor is heated and installed directly in the flue gas, eliminating the need for a flue gas extraction and conditioning system. Low cost versions of these sensors are also commonly used in automobiles. In this application, however, they are not used to accurately measure exhaust oxygen concentration. They are instead used to control the air/ fuel ratio to be roughly near the stoichiometric ratio where there is a very steep slope in the sensor output/oxygen concentration relationship. The output voltage from zirconium oxide sensors is dependent upon both the oxygen content of the exhaust gas and the local temperature. Automotive sensors are commonly unheated, relying instead on the engine heat to raise the temperature to the correct operating range. This adds an additional approximation since the temperature would have to be either controlled or measured to enable accurate exhaust gas oxygen determinations. Newer cars use heated sensors primarily to reduce the warm up time required and to improve the system stability although the temperature control is too coarse for accurate oxygen measurements.

When the flame quality is poor burners emit higher levels of smoke and CO. Measurements of one or both of these pirameters are often included in control systems in larger boilers. Smoke wh ch is a good indicator of flame quality, is difficult to measure in resident lal equipment because of the low levels which are considered to be acceptable. Excessive smoke numbers can be realized even with optical opacities well under 18. Any on-line smoke measuring system would have to be either extractive or use continuous air purging. Both would add considerable complexity. The use of $\mathrm{CO}$, instead of smoke, as an indicator of flame quality was evaluated in the experimental portion of this project.

In another approach to burner control, light emitted from a burner flame is measured in one or more wavelength bands and this information is used as an indicator of excess air and/or flame quality. In a very rough sense it is an extension of the practical observation that rich flames are dull orange and lean flames are bright yellow. Several research and development groups have worked on this approach for a broad range of applications with promising results. The most difficult applications for optical methods are those which have variable firing rate and/or variable swirl settings. Home heating oil burners have fixed firing rates. As a part of this profect detailed optical emission mecsurements were made in domestic oil-fired systems to evaluate the potential use of this method. Primary potential advantages were seen as low cost and simplicity. 
The experimental portion of this project was conducted entirely in the Brookhaven National Laboratory (BNL) Combustion Equipment Technology (CET) Laboratory. All work was almed at evaluating control options which could meet the goals of this program at low cost. This work specifically included:

\section{1) Co/Smoke Relationship}

The relationship between $C O$ and smoke emissions and burner excess air was studied to evaluate the use of $\mathrm{CO}$ as an indicator of flame quality. In all cases a measurable increase in flue gas $C O$, with decreasing flame quality, was observed only after smoke had increased to unacceptably high levels. This result essentially precludes $C O$ as a useful indicator of flame quality. It should be noted that all of these measurements were made in a conventional pressure atomized retention head burner. With air atomized burners, prevaporizing burners, and recirculating type blue flame burners, a preference towards $\mathrm{CO}$ has been observed in other studies.

\section{2) Effect of Parameters on Flue Cas Exit Temperature}

To monitor the condition of the heat exchanger surfaces the leading candidate is the temperature of the exiting flue gas. This temperature, however, is not constant but changes dramatically over each firing cycle. The steady state value can take five to ten minutes to reach. In addition, the flue temperature can be affected by the boller water temperature, excess air, and the temperature of the surrounding room. During this profect the effect of each of these parameters on the flue gas temperature was evaluated both experimentally and with the ald of a simple boller model. This was a simple one-pass parallel-flow heat exchanger model and was found to simulate the effects of parameter changes quite well.

Large transients in flue gas exit temperature which occur during normal, cyclic burner operation could be a difficulty in the use of this parameter for monitoring efficiency changes over time. These transients can, however, be handled by monitoring only changes in the peak flue gas temperature which occurs during the heating cycle. A dial type thermometer with a maximum indicating hand could be used for this, for example.

In the case of bollers the flue gas exit temperature is affected by the water temperature. This effect could be reduced by monitoring the flue gas to boiler water differential temperature.

3) Longer Term Degraded Performance Tests

Test were done to determine changes in selected parameters as heating equipment fouls. The parameters examined are candidates for use in control strategies which would monitor efficlency changes over time. This includes flue gas exit temperature, combustion chamber to flue pressure drop, flue pipe surface temperature and flue gas oxygen. Two units, a boller and a furnace were operated under forced cycles for a period of weeks, with unusually high smoke levels. 
The boller was operated with a 5 minute on- 10 minute off firing pattern and a steady state smoke number of 5 . The test duration was 36 days and during this time the burner operated for a total of 289 hours and cycled 3,472 times. With a 1.0 gallon/hour firing rate 289 gallons of oil were consumed during this test. The rise in flue gas temperature observed during this test was $131 \mathrm{~F}$ which corresponds to a decrease in thermal efficlency of 2.98 .

In the furnace tests the burner operated 10 minutes on- 15 minutes off with a steady state smoke number of 8 . The duration of the furnace test was 50 days. During this time the burner consumed 396 gallons of ofl $(1.0 \mathrm{gph})$ and cycled about 2400 times. During the test the flue gas temperature increased $74 \mathrm{~F}$ and the excess air decreased from 248 to 148 . At constant excess air this rise in flue gas temperature corresponds to a reduction in efficiency of 1.88 . With the reduced excess air this efficiency decrease is 1.28 .

These tests showed that the most consistent indicator of the efficiency degradation due to fouling is simply flue gas exit temperature. As a lower cost option the flue plpe surface temperature could also be measured. This was found to track the trend in flue gas temperature but the change was smaller in magnitude over time. Changes in the heat exchanger pressure drop were found to be too small to be practically useful.

4) Tests on Oxygen Sensors

Three zirconiura-oxide oxygen sensors were tested during this project. This included a commercially avallable system produced by Nederlandse Philips Bedrifven, B.V. (Netherlands), a typical unheated automotive type sensor, and a heated automotive sensor. The Philips unit was of particular interest because the manufacturer has used it on small commercial boilers and has been pursuing the development of a low cost unit for domestic heating applications. The unit tested during this program is essentially the larger unit used in Europe modifled for 60 cycles, 110 volt operation.

To utilize an unheated automotive type oxygen sensor in a residential system it must be located in a place where it will be heated to 900-1600 $F$. To achieve this the sensor was located in the upper region of the refractory combustion chamber of a dry base steel boller. The heated automotive sensor which uses a positive temperature coefficient electrical heating element to maintain the zirconium oxide in its proper temperature range, was installed in the flue of the same boiler. The Philips oxygen analyzer was also installed in the flue.

The output signal from the two automotive sensors was simply a voltage which varies with both oxygen concentration and sensor temperature according to the Nernst relation (see Section 2.2). To calculate the oxygen concentration the temperature of the automotive sensor casings was measured with an attached thermocouple. Because this is only an estimate of the effective temperature of the zirconium oxide the calculated oxygen concentration will only be approximate. While this approach may not be acceptable in larger bollers it may be suitable for small residential units where the costs are more constrained. The primary demand on a dedicated 
oxygen sensor is that it provide a repeatable and reliable indicator of the excess air, but not necessarily a very accurate one.

Both the heated and the unheated automotive oxygen sensors provided a repeatable signal which responded well to excess air changes. In the case of the unheated sensor, however, the difference between the calculated and meas dred oxygen concentration was very large and the response of the sensor in cyclic burner operation was unacceptably slow. The heated sensor produced much better time response and calculated excess air levels agreed to within about 158 of those measured independently. In quantity, the estimated costs of the unheated and heated automotive sensors are $\$ 20$, and $\$ 30$. respectively.

The output from the Philips unit is flue gas oxygen concentration directly. This unit preformed very well, accurately indicating oxygen concentration even at very high smoke numbers. No fouling of this sensor or change in its output was observed in 6 hours of cycling operation with the burner set for a steady state smoke number of 9 .

5) Measurements of Flame Optical Emissions

Studies of flame optical emissions for control purposes evolved during the coarse of this program into a primary focus. This occurred because the preliminary results indicated good promise for low cost approaches toward indicating flame quality.

Measurements of the intensity of light emitted from oil burner flames were made as a function of wavelength ("spectral intensity") using an arrangement illustrated in Figure $S-1$. In this arrangement a liquid light guide is used to carry the light signal from the burner air tube area to an external monochrometer which separates the light into narrow wavelength bands, and finally to a detector. Additionally, some measurements were made using simply a plain sensor located in the burner air tube just behind the retention head. These were "broadband" measurements because the sensors used responds to light over a wide wavelength range.

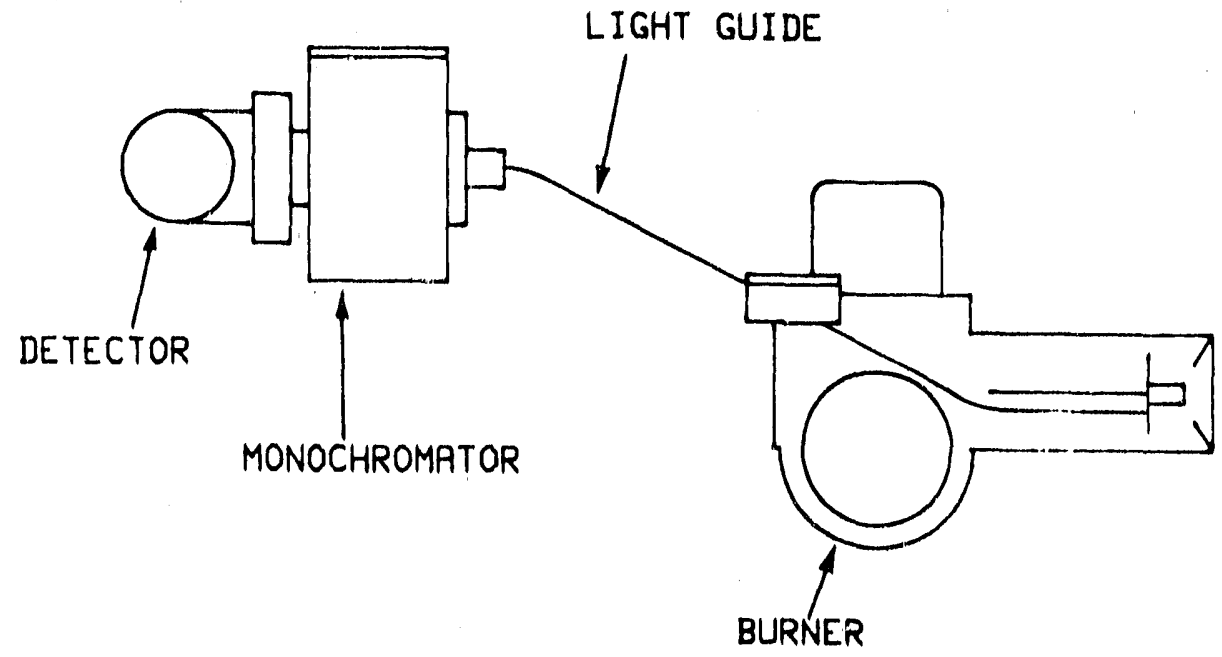

Figure S-1. Optical Arrangement for Spectral Intensity Measurements. 


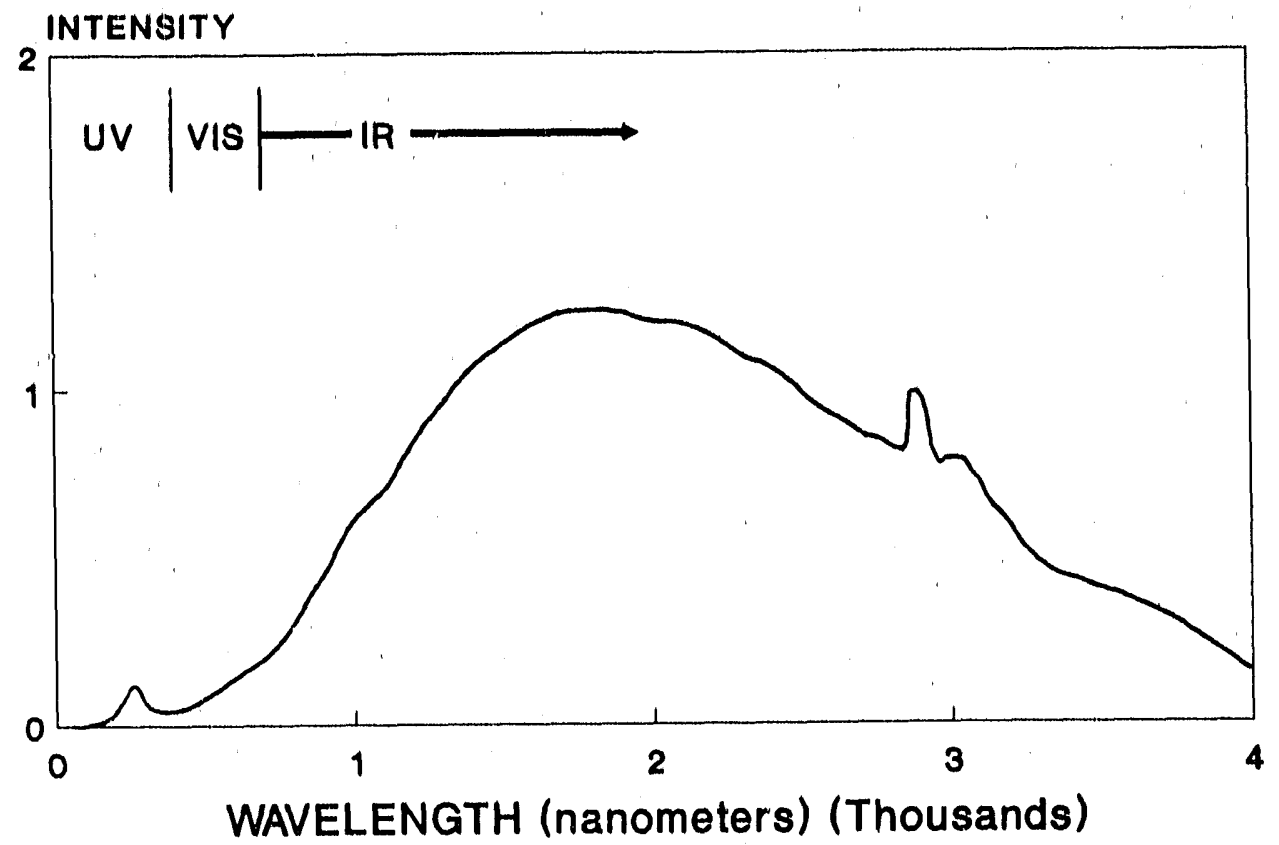

Figure S-2. Illustration of the spectral intensity of radiant energy emitted from an oil burner flame showing both "continuum" and narrow band peaks. [Note. This figure is for illustration only and is not derived from specific data. UV - ultraviolet; VIS - visible $(400-700 \mathrm{~nm})$; IR - infrared]

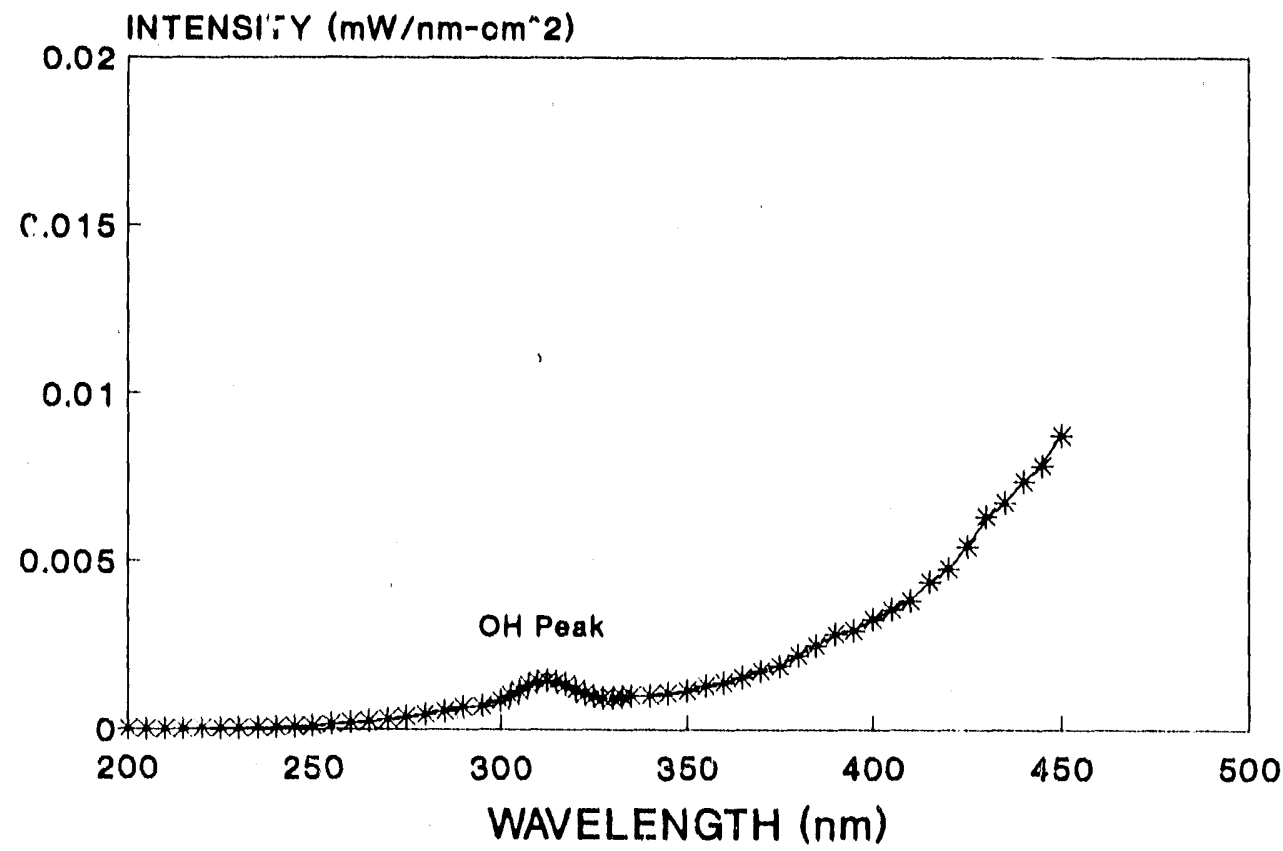

Figure S-3. Example of measured spectral intensity of radiant energy from an oil flame over the ultraviolet and part of the visible range. 
The general nature of the light emitted from oll burner flames is illustrated in Figure S-2. The emission could be considered to have two baslc parts. The first is the "continuum" emission which is like a black body curve and is due to emissions from soot particles in the flame. The second part is smaller peaks due to emissions from specific gas phase species in the flame. An example of the data obtained over the ultraviolet (UV) and part of the visible range is provided in Figure S-3. This clearly shows the peak centered at 310 $\mathrm{nm}$ wavelength which is due to emission from $\mathrm{OH}$. The remainder of the emission is the continuum emission.

These optical studies were performed over a broad range of conditions. Parameters examined in this work included excess air, firing rate, nozzle spray pattern, nozzle condition, fuel quality, combustion chamber refractory liners, and transient effects during cyclic operation.

General conclusions include the following:

1) As burner excess air increases the continuum intensity decreases, the apparent flame color tends to increase, and the intensity of the $\mathrm{OH}$ peak in the UV is falrly constant.

2) Simply monitoring the intensity of the broadband emission from the flame was found to be a very useful indicator of the excess air. It is possible, for example, to set the excess air in the burner to produce a specific level of broadband intensity. This could be accomplished using a simple sensor like a cadmium sulfide photoconductor ("Cad Celi"). The setpoint established in this way was found to produce an acceptable setpoint with a wide range of nozzles from 0.5 to $1.0 \mathrm{gph}$. The setpoint was found, however, to be dependent on the details of the combustion chamber and refractory liner which the burner is fired into.

3) Monitoring of the "color" of the flame, which could be done through the ratio of the continuum intensity in two wavelength regions, was found to be useful only if the flame was viewed from the back end of the boller. An advantage of using a ratio of two intensity signals is reduced sensitivity to fouling of the sensor heads. Viewing the flame from the back end of the boller has the disadvantage of requiring an added penetration into the combustion chamber. In addition an air purge would be required to keep the sensors cool. When the flame is viewed from within the burner air tube normal combustion air flow serves to cool the sensors. Color was not found to be consistently useful from this viewpoint, however.

4) As an alternative to using simple continuum intensity for indicating flame condition the ratio of the continuum intensity to the intensity of the $\mathrm{OH}$ peak could be used. This should provide a system less sensitive to drift due to sensor fouling. The addition of the $\mathrm{OH}$ signal would add considerably to the cost, however.

Considering the results of these optical measurements one control system approach was selected for additional development. This is the use of a single, broadband sensor mounted within the burner air tube for 
indicating flame brightness. If used in a specific burner mounted in a specific combustion chamber this system could be used to aid in the initial adfustment of the burner. For general refit in existing systems or arbitrary new units the system could be used to monitor performance changes between service calls. The setpoint in this general case would have to be established at each site. With this simple approach, the burners would be serviced before the efficiency has degraded due to soot fouling of the heat exchanger. Equipment reliablilty would be improved greatly. The cost associated with this system is estimated to be about $\$ 20$.

\section{Control System Options}

Experimental results from this project suggest a number of approaches for control systems. The simple optical system discussed above could be very useful for monitoring changes in flame quality between service calls. As a next step an approach of this type could be used for adjusting excess atr. This would provide a rapid, accurate method of adjusting burners during servicing. Results of measurements with different equipment, however, have shown that the setpoint is dependent upon the combustion chamber. For this reason such a simple system would be most readily adapted in new matched boiler/burner units. As a further step, burners which have automatic excess air trim could be considered. For this purpose neither an optical sensor nor a flue gas oxygen sensor alone would provide a reliable input signal and both should be used. Implementation of excess air trim could be done using dampers, a variable speed burner pump motor, or, in the case of induced draft systems, a variable speed draft inducer. A burner system with automat:c control of this type would roughly double the burner cost.

Four speciflc control approaches are listed below and compared with regard to cost and potential savings.

\section{Approaches}

1. Peak Hold Dial

Type Thermometer

2. Optical Flame

Quality Monitor

(single sensor)

3. Optical Service

Tool

4. Automatic Feedback

Air Trim $\underline{\text { Cost }}$

$\$ 35$

$\$ 20$

$\$ 20$

$\$ 150$
Potential

Savings (8) Payback (Years)

Because of the attractiveness of the simple optical flame monitor, work is continuing to establish the reliability of this system under actual field conditions, and its market potential. 
PAGE

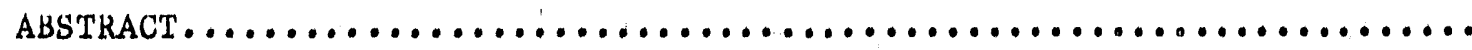

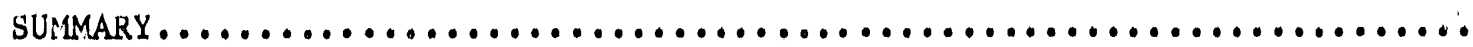

LIST OF FIGURES......................................

LIST OF TABLES......................................

DEFINITIONS AND NOMENCLATURE $\ldots \ldots \ldots \ldots \ldots \ldots \ldots \ldots \ldots \ldots \ldots \ldots \ldots \ldots$

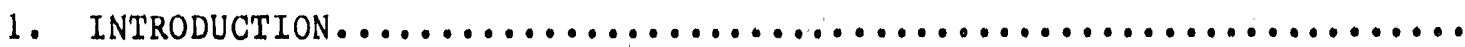

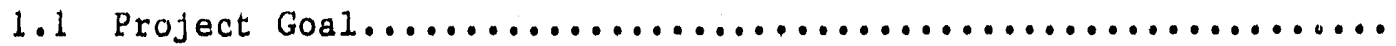

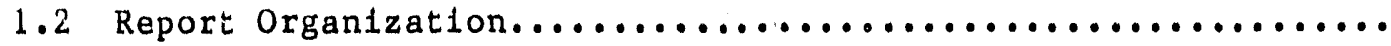

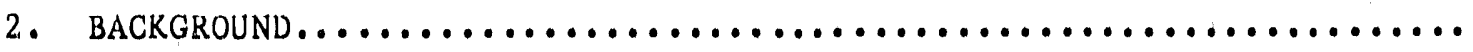

2.1 Control Practice in Commercial and Industrial Boilers.........

2.2 Methods of Analysis of Combustion Products.................

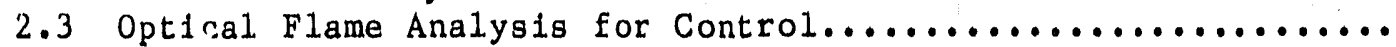

3. EXPERIMENTAL APPARATUS AND MEASUREMENTS $\ldots \ldots \ldots \ldots \ldots \ldots \ldots \ldots \ldots \ldots$

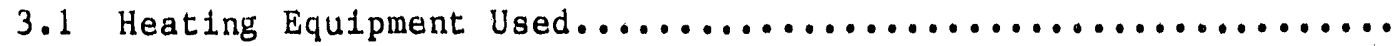

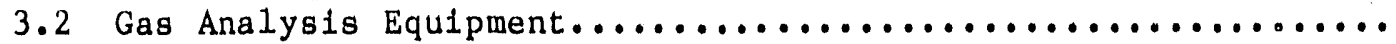

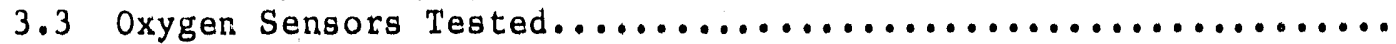

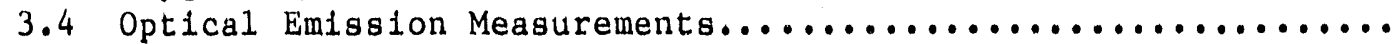

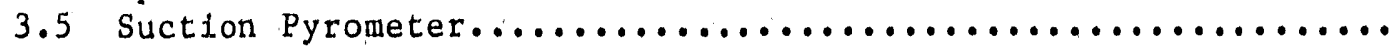

4. RESULTS........................................

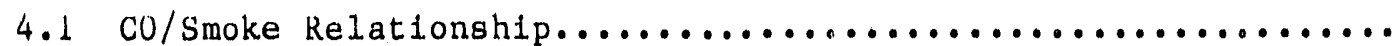

4.2 Effect of Parameters on Flue Gas Exit Temperature............

4.3 Longer Term Degraded Performance Tests...................

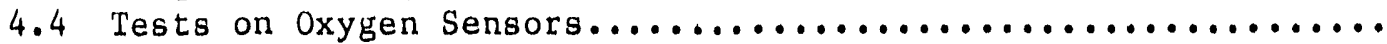

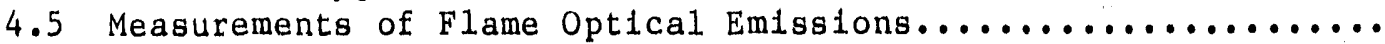
4.5.1 Conventional Retention Head Burner Flame, Vlewed from

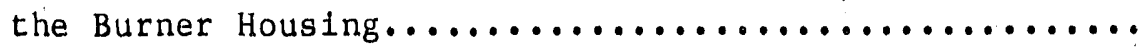
4.5.2 Conventional Retention Head Burner, Vlewed froin the

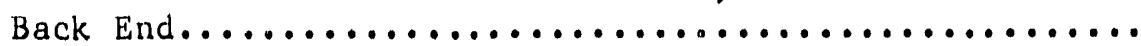

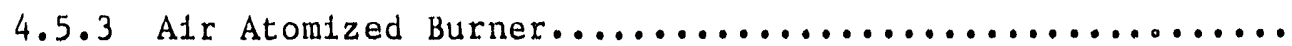

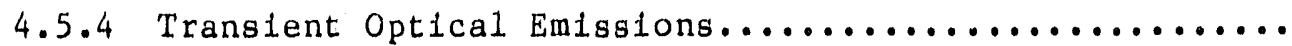

5. CONTROL SYSTEM OPTIONS.............................

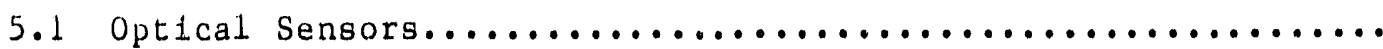

5.2 Telephone Link for "Service Required"...................

5.3 Implementation of Active Excess Air $\operatorname{Tr} i m \ldots . \ldots \ldots \ldots \ldots \ldots \ldots$

6. DISCUSSION OF CONTKOL STRATEGIES......................

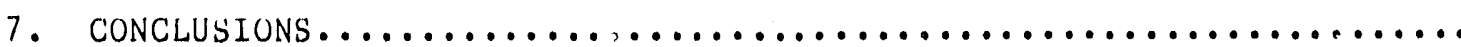

111

Iv

$x i v$

xVI1

$x \vee 111$ 
TABLE OF CONTENTS (Cont.)

PAGE

8. RECOMMENDATIONS FOR FUTURE CONTROL SYSTEMS.................. 94

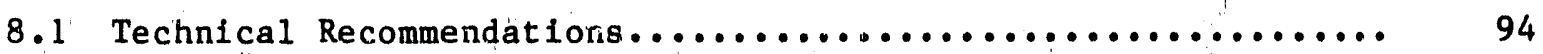

8.2 Programmatic Recommendations....................... 95

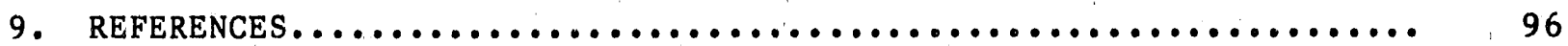


Figure 1. Figure 2.

Figure 3. Figure 4.

Figure 5. Figure 6.

Fig'tre 7.

Figure 8. Figure 9. Figure 10.

Figure 11.

F1gure 12.

Figure 13.

Figure 14. Figure 15.

Ff.gure 16.

Figure 17.

Figure 18.

Figure 19.

Figure 20.

Figure 21.

F1gure 22.

Figure 23.

Figure 24.

Figure 25.

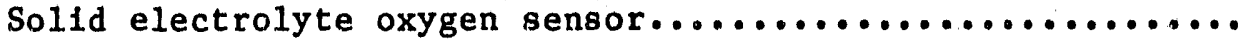
Output voltage of solid electrolyte oxygen sensor (from $\operatorname{Ref} .3) \ldots \ldots \ldots \ldots \ldots \ldots \ldots \ldots \ldots \ldots \ldots \ldots \ldots \ldots \ldots \ldots . \ldots \ldots$

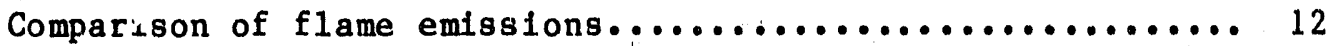
Cross section 1llustrating wet base, two pass boller used for optical studies.......................... 15

Sampling train for combustion shamber gas analysis......... 17 Illustration of the location of the unheated automotive type oxygen sensor in the combustion chamber.............. Details of the installation of the unheated automotive oxygen sensor in the combustion chamber................ 20 Optical arrangement for spectral intensity measurements..... 21 Location of $\mathrm{PbSe}$ sensor in burner air tube................ 23 Measured smoke number and $C O$ emissions over a range of excess air levels. Hot water boller, $0.65 \mathrm{gph} . . . \ldots . . . . .26$ Measured smoke number and $C O$ emissions over a range of excess atr levels. Hot water boller, $1.00 \mathrm{gph} . . . . . . . . . .26$ Meacured smoke number and $C O$ emissions over a range of excess air levels. Condensing warm air furnace, $0.5 \mathrm{gph} . . .27$ Measured smoke number and $\mathrm{CO}$ emissions over a range of excess air levels. Warm air furnace, $1.00 \mathrm{gph} . \ldots \ldots \ldots . . . .27$ Location of sampling points in combustion chamber.......... 28 Measured smoke number and $\mathrm{CO}$ emissions over a range of excess atr levels. Hot water boiler, $0.65 \mathrm{gph}$. Sampling

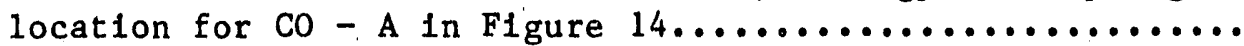
excess air levels. Hot water boller, $0.65 \mathrm{gph}$. Sampling

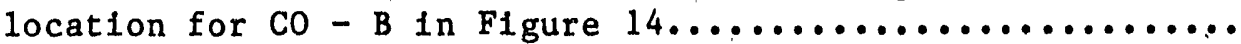

Relationship between $C O$ and smoke number with three sampling locations for $\mathrm{CO}$. Hot water boiler, $0.65 \mathrm{gph} . . . .31$ Smoke number vs excess afr with a fouled nozzle. Hot vater boller. Noilnal nozzle rating - $0.65 \mathrm{gph} . \ldots . . . . . . .31$ Illustration of a boller (or furnace) as a simple,

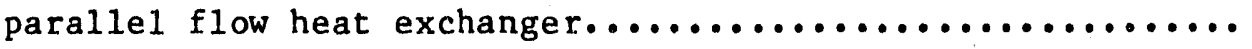
boiler, $0.65 \mathrm{gph}$. Data $(\cdot)$ and trend predicted by simple heat exchaiger model $(-) \ldots \ldots \ldots \ldots \ldots \ldots \ldots \ldots \ldots \ldots . \ldots . \ldots 32$

Temperature difference between the stack and the boller water over a range of water temperatures, $0.65 \mathrm{gph} . \ldots . \ldots . .34$ Effect of excess air on flue gas temperature. Warm alr furnace, $1.0 \mathrm{gph}$. Data $\left(\bullet^{\bullet}\right)$ and trend predicted by simple heat exchanger model...................... 34 Effect of changing furnace alr flow on stack temperature. Data $\left({ }^{\bullet}\right)$ and simple heat exchanger model.... 36 Measured smoke numbers over a typical firing cycle Boiler longer term performance test................. 38 Flue gas exit temperature. Cycle maximum - Botler longer

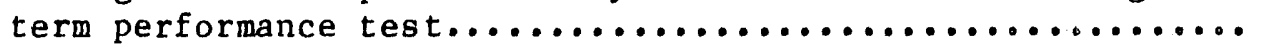


Figure 26. Flue pipe surface temperature - Cycle maximum boiler

longer term performance test........................

Figure 27. Measured smoke numbers over a typical firing cycle -

Furnace longer term performance test...................

Figure 28. Excess air based on commerctal zirconium probe -

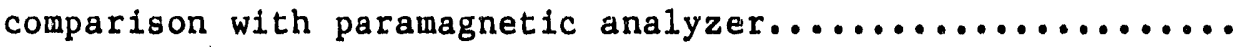

Smoke number vs. excess air for test 11lustrated in

Figure 29.

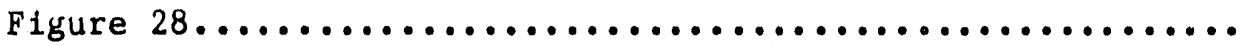

Figure 30. Commercial zirconium probe - indicated flue gas $\mathrm{O}_{2}$

Figure 31. Unheated automotive type oxygen sensor - output signal

and measured temperature as a function of excess air...... 43

Figure 32. Excess alr based on unheated automotive type sensor comparison with paramagnetic analyzer..................

Figure 33. Unheated automotive type oxygen sensor - output signal and reasured temperature over a firing cycle............. 44

Figure 34. Heated automotive type oxygen sensor - output signal as a function of sensor temperature and $\mathrm{O}_{2}$ (paramagnetic

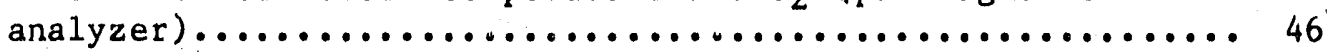

Figure 35. Excess air based on heated automotive type oxygen sensor at $1100^{\circ} \mathrm{F}$ - comparison with paramagnetic analyzer......... 46

Figure 36. Heated automotive type oxygen sensor - output signal and measured temperature over a firing cycle................

Figure 37. Measured smoke number and $C 0$ emissions over a range of excess air levels. Prototype vaporizing oil burner......

Figure 38. Heated automotive type oxygen sensor - output signal as
as function of excess air in prototype vaporizing oil

Figure 38. Heated automotive type oxygen sensor - output signal a
as function of excess air in prototype vaporizing oil

Figure 39. Excess air based on heated automotive type oxygen sensor in prototype vaporizing oil burner - comparison with

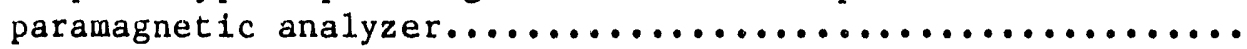

Figure 40. Flame optical emission spectra over the visible range $(450-700 \mathrm{~nm})$ and a part of the UV-retention head burner

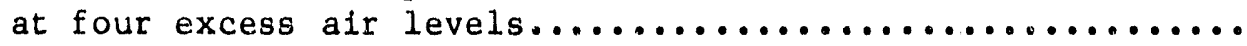

Figure 41. Flame optical emission intensity as a function of excess air at selected wavelengths in the visible - retention

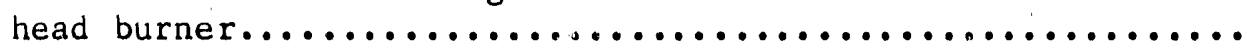

Figure 42. Ratio of optical emission intensities at 600 and $400 \mathrm{~nm}$ as a function of excess air - retention head burner........

Figure 43. Flame optical emission spectra over the ultraviolet range $(200-450 \mathrm{~nm})$ - retention head burner at four excess

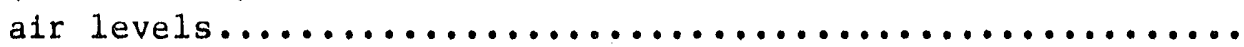

Figure 44. Flame optical emission intensity as a function of excess air at selected wavelengths in the ultraviolet (note -

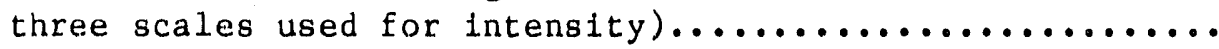

Figure 45. Smoke number over a range of excess air levels - retention

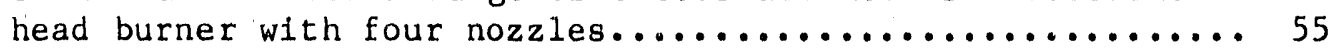

Figure 46. Flaine optical emission intensity at $450 \mathrm{~nm}$ as a function of excess air - retention head burner with four nozzles.... 
Figure 47. Flame optical emisston Intensity at $450 \mathrm{~nm}$ as a function of smoke number - retention head burner with four nozzles..... 57

Figure 48. Ratio of optical emission intensities at 450 and $310 \mathrm{~nm}$ as a function of smoke number - retention head burner

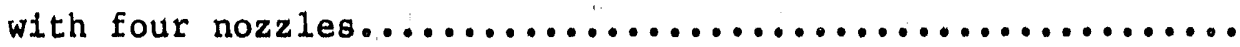

Figure 49. Excess air setpoints based on continum emission at $410 \mathrm{~nm}$ and ratio of intensities at 410 and $310 \mathrm{~nm}$ - retention head burner with four nozzles...........

Figure 50. Smoke number and response of broad band sensors vs. excess air - retention head burner................... 59

Figure 51. Optical emission spectra with a combustion chamber........60 Figure 52. Optical emission spectra without a combustion chamber......61 Figure 53. Measured flame temperature along combustion chamber axis.... 62 Figure 54. Resistance of cadmium sulfide photoconductor as a function of steady state smoke number for eight nozzles - retention head burner......................................... 64

Figure 55. Resistance of lead selenide photoconductor as a function of steady state smoke number for eight nozzles - retention

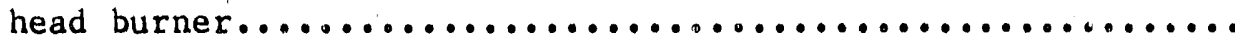

Figure 56. Excess air setpoints based on resistance of cadmium sulfide and lead selenide photoconductors retention head burner with elght nozzles.................. 61

Figure 57. Resistance of cadmium sulfide photoconductor in forward position as a function of steady state smoke number for eight nozzles - retention head burner..................

Figure 58. Excess air setpoints based on the resistance of the cadmium sulfide photoconductor at the forward location..... 70

Figure 59. Viewpoint at the end of the combustion chamber. Intensity at $550 \mathrm{~nm}$, three nozzles.................. 72

Figure 60. Viewpoint at the end of the combustion chamber. Intensity ratio vs. smoke number, three nozzles.......... 72

Figure 61. Air atomized burner. Smoke number/excess air relation..... 74

Figure 62. Air atomized burner. Intensity at $550 \mathrm{~nm}$ vs. excess air. Vlewpoint at end of the combustion chamber..............75

Figure 63. A1r atomized burner. Intensity ratio vs. excess air. Viewpoint at end of the combustion chamber............. 75

Figure 64. Smoke number and response of broadband sensors over a firing cycle - retention head burner................. 76

Figure 65. Cad cell resistance over a firing cycle-wet base boiler.... 77 Figure 66. Illustration of the relationship between light intensity and resistance of a cad cell................ 80

Figure 67. Schematic of a simple comparator circuit for indicating cad cell resistance............................. 82 


\section{LIST OF TABLES}

PAGE

Table 1. Fuel Propertles.................................. 54

Table 2. Common Types of Opt1cal Sensors....................... 86 


\section{DEFINITIONS AND NOMENCLATURE}

Some of the terms which are used in this report may not be familiar to all readers. To make the report generally more understandable and to ensure that the intended points are communicated, definitions for selected terms (primarily dealing with light emission studies) are provided below:

Adiabatic flame temperature -

Banded radiation. -

Broadband -

Continuum -

Emission spectra -

IR -

Luminous -

$\mathrm{mW} / \mathrm{nm}-\mathrm{cm}^{2}-$

Monochrometer -

$\mathrm{nm}-$

Spectral

intensity -

Stoichiometric -

UV - the temperature that a flame would reach if there were no heat loss from the combustion zone.

radiant energy emitted from a body which is contained within one or more specific, narrow wavelength bands.

with a very wide wavelength band. In this report some sensors are referred to as broadband. This means that these sensors respond to light over a wavelength range. An example of this is the cadmium sulfide photoconductor ("cad cell") which responds to all visible light and also infrared light over a limited range.

light which varies in intensity smoothly as wavelength changes. Light from a black body is a continuum. Light from specific gas phase species in flames shows sharp peaks only at specific wavelengths. This type of light emission is not a continuum.

this refers to illustrations of emitted radiant energy as a function of wavelength.

infrared

emitting visible light. 011 burner flames are typically luminous because of the visible light emitted by incandes. cent particles.

unit used in this report to express spectral intensity. The light energy hitting the sensor per unit sensor surface area and per unit wavelength bandwidth.

an instrument which transmits light in a narrow wavelength band. The wavelength transmitted is adjustable. When used with a suitable detector a monochrometer can be used to study the spectral intensity of a light source.

nanometers (1000 nm -1 micron); wavelength unit

intensity of radiant energy as a function of wavelength.

(air/fuel ratio) - the correct air/fuel ratio for a specific fuel. At the stoichometric air fuel ratio there is exactly enough air avallable to completely burn all of the fuel.

ultraviolet 


\section{INTRODUCTION}

The thermal efficiency of residential ofl fired heating equipment in service is lower than the efficlencles which can be achleved linder controlled conditions. Two primary factors contribute to this situation.

- When equipment is installed and serviced, the burners are not adfusted for minimun excess air.

- In continuous service, thermal performance deterforates between tuneups. This is due in part to soot accumulation on the heat exchanger surfaces.

For maximum thermal efflciency ofl burners should have their alr/fuel ratios adjusted to produce a "trace" smoke level in the flue. (A "trace" smoke is equivalent to a smoke number between 0 and 1 on the She11/Bacharach Scale). A burner adjusted this way in steady state, however, will have significantly higher smoke levels during routine, cyclic operation. This ls due to three factors: 1) an ignition pressure peak in the combustion chamber which has been shown to produce increasingly severe smoke peaks as excess alr is reduced [1]; 2) immediately following ignition the average temperature in the chimney is lower than in steady state, leading to reduced draft and excess air; and 3) immediately following ignition the combustion chamber walls are still relatively cold, also leading to increased smoke. In addition, changes in fuel quality between service calls and excess alr changes due to weather conditions wight produce a soot problem for burners set with "marginal" excess alr. Service personnel adjust burners to have generous excess air levels to prevent problems which might require a return visit to the home. Unfortunately, this results in a relatively poor operating efficlency compared with the maximum level that can be achleved.

Increasing excess atr decreases efficiency by increasing the mass flow rate and temperature of the combuation products diacarded to the outdoors. To 111ustrate the magnitude of the effect it is assumed that a burner 1s adjusted to $y \% \mathrm{CO}_{2}$ instead of an optimal level, of $12 \%$. Th1s corresponds to $68 \%$ excess air vs. the optimal level of about $30 \%$. Stack gas temperature would be about $70^{\circ} \mathrm{F}$ higher due to the unneeded excess alr (Note - this is based on results in section 4.2 of this report). The steady state efficlency would be about $6 \%$ lower as a result of the two effects.

The above discussion assumes that the service personnel have the adequate instrumentation to properly set the alr/fuel ratio and that they spend the time required to make these adfustments. In many cases burners are installed without proper adjustment leading to very high excess air settings with reduced efficiency and/or service problems.

Estimates of the magnitude of the annual degradation in thermal efficlency based on earlier published studies, show considerable rarlation between units. An average degradation of $2 \%$ per year has been used [2]. Some add1tional data on degradation rates is avallable from a recent study performed by the Alliance to Save Energy [3], on energy savings associated with the refit of flame retention head burners in low Income housing. Initially, with the new burners, efficlency increased by an average of $20 \%$. Over the five years following the refit one-third of that efficiency increase was lost. Princlpal 
causes of deterforation are seen as fouling of the heat exchanger surfaces by soot, fouldng of the ofl nozzle, and changes in afr/fuel ratio caused by dust accumulation on the air inlets. Sooting appears to be the key degradation process.

Generally, the introduction of advanced control systems could potentially reduce fuel consumption due to both high excess atr and heat exchanger fouling.

\subsection{Project Goal}

The goal of this profect is to develop recommendationg for control strateytes and systems for tmproved efflctency of ofl-fired residential equipment, based on curtent technology.

Two basic control modes can be considered for malntalning high efficlency operation:

- Service-required signals - In this mode the homeowners or service company would be made aware that amoke production and/or efficlency have degraded to the point that service lo required.

- Steady-state excess-air trim - In this mode the burner would essentially tune itself continuously for maximum efficlency. Excess alr would be changed in response to changes in fuel quality, draft, nozzle erosion, etc. to maintain "trace" smoke in ateady state.

In limplementing these control strategles an input is required which to related to alr/fuel ratio and/or flame quality. This type of input could alternatively be used as a service tool. Instead of making excess alr and smoke number measurements at a series of polnts and then selecting a setpolnt, the excess atr could aimply be adjusted until a predetermined control signal 1s reached. The development, of sensor inputa for advanced service tools, while not truly a "control" is considered as a part of the goals of this project.

The service-required signal. mode would reduce fuel consumption by reducIng operating time in a degraded condition. The control approach intght be as sinple as monttoring stack temperature as an lndicator of fouling. The stimplicity of this approach is a great advantage. A disadvantage of this approach, however, is that the homeowner is alerted only after the heat exchanger surfaces have become fouled. A control system which alerts the homeowner when the burner has Just started produclng high smoke could eliminate the need for disassembly and cleaning of the unit. Potentlally this mode could be achleved by measuring smoke, gaseous hydrocarbons, Co, or flame optical emissions ("color").

\subsection{Report Organization}

Control systems are routinely used in larger comnercial-sector and industifal boller applications. In Section 2.1 of this report, control practice in these systems and the relevance to smaller residential applicaLions is reviewed. 
In larger boller aystems, controlo commonly use flue gas oxygen content, Co, combustibles or opacity. Technology for $\mathrm{O}_{2}, \mathrm{CO}$, and combustibles sensors, which has advanced significantly in the past ten years, lo revlewed in Section 2.2 of this report.

Optical methods of flame diagnostlco have recelved increaging attention In recent yeara. Thla approach has been applied to systema ranging from pulverized coal-fired utility bollers to kerosene-flred space heaters. In Section 2.3, progress fil thls area and Lta potentlal are discussed.

I'o monttor the condition of the heat exchanger surfaces the leading candidate to the temperature of the extiting flue gas. This temperature, however, 1s not constant but changes drainatically over each firfing cycle. The ateady at te value can take five to ten minutes to reach. In addition, the flue temperature can be affected by the boller water temperature, excesa alr, and the temperature of the surrounding room. During this project the effect of each of these parameters on the flue gas temparature was evaluated both exper1mentally and with the ald of a almple analytical model.

When a burner 18 operated without sufficlent combustion air or has lowquality atomization the result is the emission of products of incomplete combustion: carbon monoxide, hydrocarbons and "soot." For control purposes any one of these three could be consldered as an lindicator of poor quality combustion and the need for etther service or additional excess alr. Durlng this project the relationship between smoke and carbon monoxide was atudied experimentally for typlcal residental heating equipment. CO was considered particularly important because of 1 to use for this purpose 1 n larger bollers. The relationship between smoke and gaseous hydrocarbons was not examined in this speclfic project although some information on this relationship lo aval1able from other BNL projecta. Generally flue gas hydrocarbons are a poor Indicator of smoke - Increasing algniftcantly only at very high smoke levelo.

Control sygtems for larger bollers frequentily use zlrcontum oxide probes to measure flue gas oxygen concentration as an Indlcator of excess alr. These probes are typlcally falrly large and expenglve relative to the residential application. Experfinental studies on low cost zircontum sensors which might be used for home heating aystems have been performed during this profect.

Because of the $r$ potential simplicity, optical measures of flame condition could be very useful for restdential ofl burners. Data on the spectral lintensity of emfted radiation have been obtulned over a broad range of: conditions to evaluate this approach.

Detallo of the experimental methods are described in section 3 of this report and regults are degcribed in Section 4. In gelecting any control strategy an linportant conslderation 18 the avallablilty and cost of sultable sensors and indicators or actuators. In Section 5 methods of implementing the optical. measurements, shown to be useful in Section 4, are discussed. Also discussed are the methods and costs for a local flane quality indlcator, a telephone link system, and active excess afr trim. In Section 6 Integrated control strategles which are suggested by the work in this project are compared in cost, energy savings potential and practical factors. Conclustons are listed in section 7 and in Section 8 apectiflc recommendations for future control systems are discussed. 


\section{BACKGROUND}

\subsection{Control Practice in Commerclal and Industrial Bollers}

A wide varlety of 8 rgtems which control atr/fuel ratto are commonly used on commerclal and light indugtrial bollers. Current practice and expertence in this area provide a base for considering such systems on a residential scale. Bollers in this category are typlcally fully modulating and the control systems function to vary the alr/fuel ratio over the load range, Increasing excess atr as firling rate decreases to avold smoke. Control systems vary widely and can be roughly categorized with increasing complexity as follows:

1. Preset alr/fuel ratio profile

2. Feed forward $-\mathrm{O}_{2}$ trim

3. $\mathrm{O}_{2}$ feedback

4. $\mathrm{O}_{2}$ and $\mathrm{CO}$ feedback

The most common method of implementing a preat alr/fuel ratio profile over the load range 1s with a slmple mechanlcal 1inkage or "jackshaft" controlling both fuel and atr flow. An adfustable profile cam on the fuel valve allows for manual modification of the relationship between alr/fuel ratio and load. Pneumatic or electrical actuators could also be used in place of the mechantcal 1Inkage.

In the next level of complextty, feed-Eorward control, fuel and alr flow rate are measured and adfusted automatically to produce the desired alr/fuel ratto over the load range. Relative to the preset alr/fuel ratio method this mode can compensate for changes in atmospheric conditions, fuel pressure in systems firing gas and somo changes in burner adfustment or performance.

With the third level of control, $\mathrm{O}_{2}$ feedback, flue-gas oxygen is measured (typlcally with a zirconium probe) and this is fed back to trim the alr/fuel ratio. A disadvantage of feedback aystems based on $0_{2}$ only is a strong effect of alr Infiltration into the flue. Another limtation of trim systems based on $\mathrm{O}_{2}$ alone 18 an lnablilty to detect a burner which is operating badly because of some upset not related strictly to excess air (e.g. fouled nozzle or high viscosity ofl).

This last: considcration is addressed by the fourth mode in which a Co monltor lo added. Hydrocarbons or opacity could replace or supplement CO but. this 1s less cormon, particularly in small boliers. The advantage seen for $\mathrm{CO}$ Is that l.t generally "leads" other parameters when excess alr ts decreased.

\subsection{Methods of Analysis of Combustion Products}

\section{Oxygen Analyzers}

Avallable oxygen meagurement methods can be divided lnto the following four broad categortes: 
1. Paramagnetic

2. Wet Electrochemical

3. Solld tilectrolyte (zirconfum oxide)

4. Semfonductors

Paramagnetic analyzera take advantage of the magnetic susceptibility of $\mathrm{O}_{2}$. Detallg of the analyzer deslgns vary but the basic approach 1o simllar in most systems. The extracted gas sample lo dried and filtered and fed to the measurement chamber at a controlled temperature. A magnetic field 1s imposed which creates a "magnetic wind," the strength of which 1 s dependent upon oxygen content. These analyzers are frequently used in laboratory applications but are generally not used in smaller boller control applications.

Wet electrochemical sensors are very commonly used in low-cost, portable oxygen analyzers. The sensor 1 s an electrochemical cell with an aqueous electrolyte solution. Cell life 18 typlcally 6 to 9 months and 18 limlted by anode consumption. Wet electrochemical based systems are generally not intended for continuous service and must be fed flue gas which has been cleaned, cooled and dried.

Of the oxygen measuring methods, the solld electrolyte 1s perhaps the most 1mportant because of 1 ts widespread use for combustion control applications. Figure 1 lilustrates a solld electrolyte sensor schematically. It consists of the electrolyte (zirconfum oxide ceramic partially atablilaed with yttrium) and porous platinum electrodes on the reference and flue-gas sides. At high temperatures the solid zirconium ceramic becomes conductive to oxygen lons $\left(U^{*}\right)$. An externel voltage is produced which is related to the Flue gas oxygen content, the reference gas oxygen content, and the temperature by the Nernst equation:

$$
V=0.0119 \cdot \mathrm{T} \cdot \operatorname{Ln} \frac{\left\lfloor\mathrm{O}_{2}\right\rfloor_{\mathrm{R}}}{\left[\mathrm{O}_{2}\right\rfloor_{\mathrm{F}}}
$$

where

$$
\begin{aligned}
V & =\text { output voltage (mv) } \\
\mathrm{T} & =\text { temperature }\left({ }^{\circ} \mathrm{R}\right) \\
\left\lfloor\mathrm{O}_{2}\right\rfloor_{\mathrm{R}} & =\text { oxygen partial pressure on the reference (ambient) slde } \\
{\left[0_{2}\right\rfloor_{\mathrm{F}} } & =\text { oxygen partial pressure on the flue gas side }
\end{aligned}
$$

Figure 2 1lluatrates the relationshlp between output voltage and excess aif for a zirconfun-oxlde oxygen sensor over the range of $\mathrm{O}_{2}$ concentrations typlcally found in the flue gas from residential ofl-fired heating equipment. At the stolchlometric fuel/air ratio ( $0 \%$ flue gas $\mathrm{O}_{2}$ ) there 18 a large change In the output voltage (termed the "lambda Jump") which lo somewhat tnsenslttve to sensor temperature. Thlo behavior 18 used in automotive applications to control the alr/fuel ratio near stodchiometric in englnes equtpped with catalytic converters. These systems do not use heaters to control the sensor temperature and so cannot be used to accurately determine alr/fuel ratto under lean condtitions. 


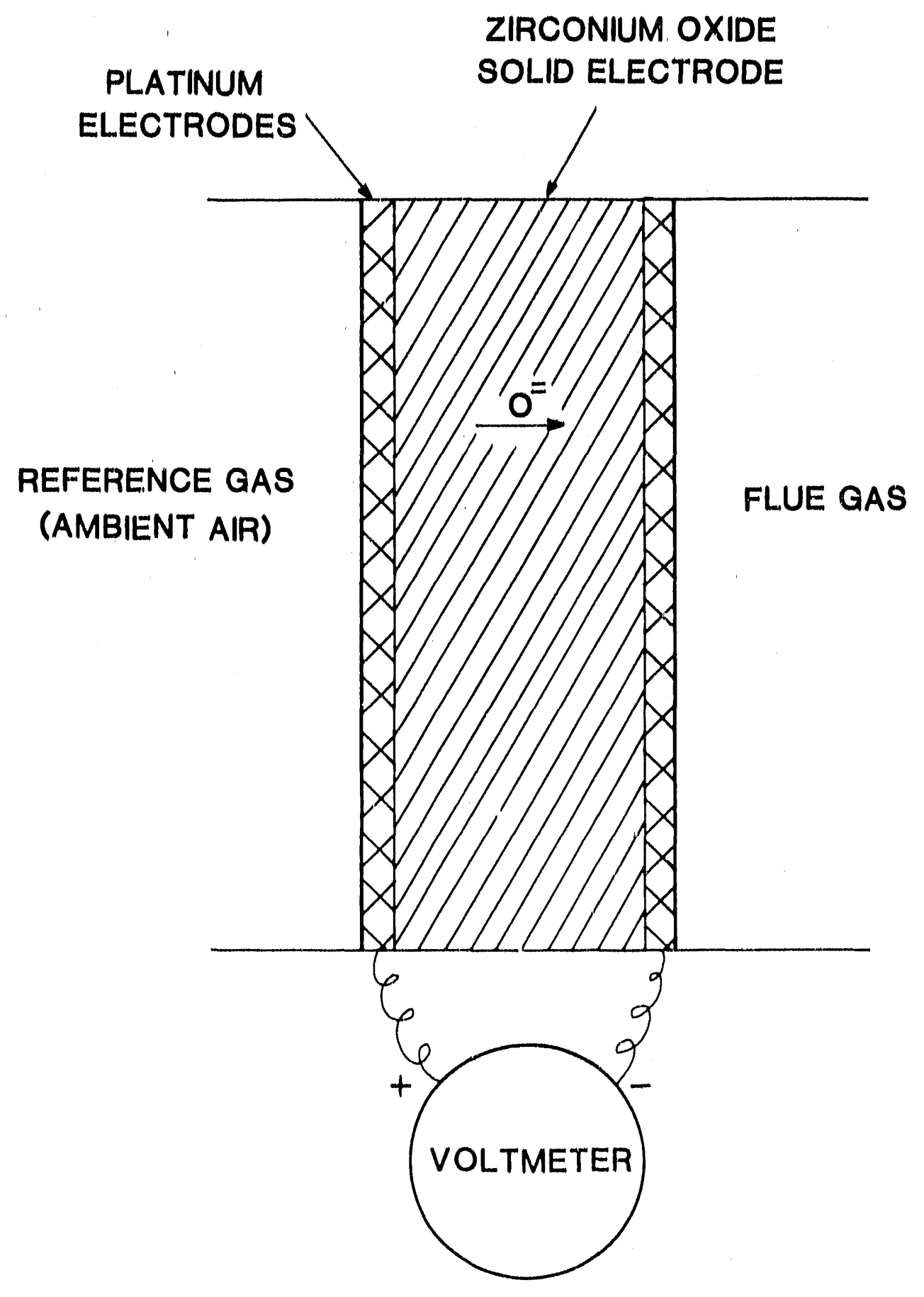

Figure 1. Solid Electrolyte oxygen Sensor. 


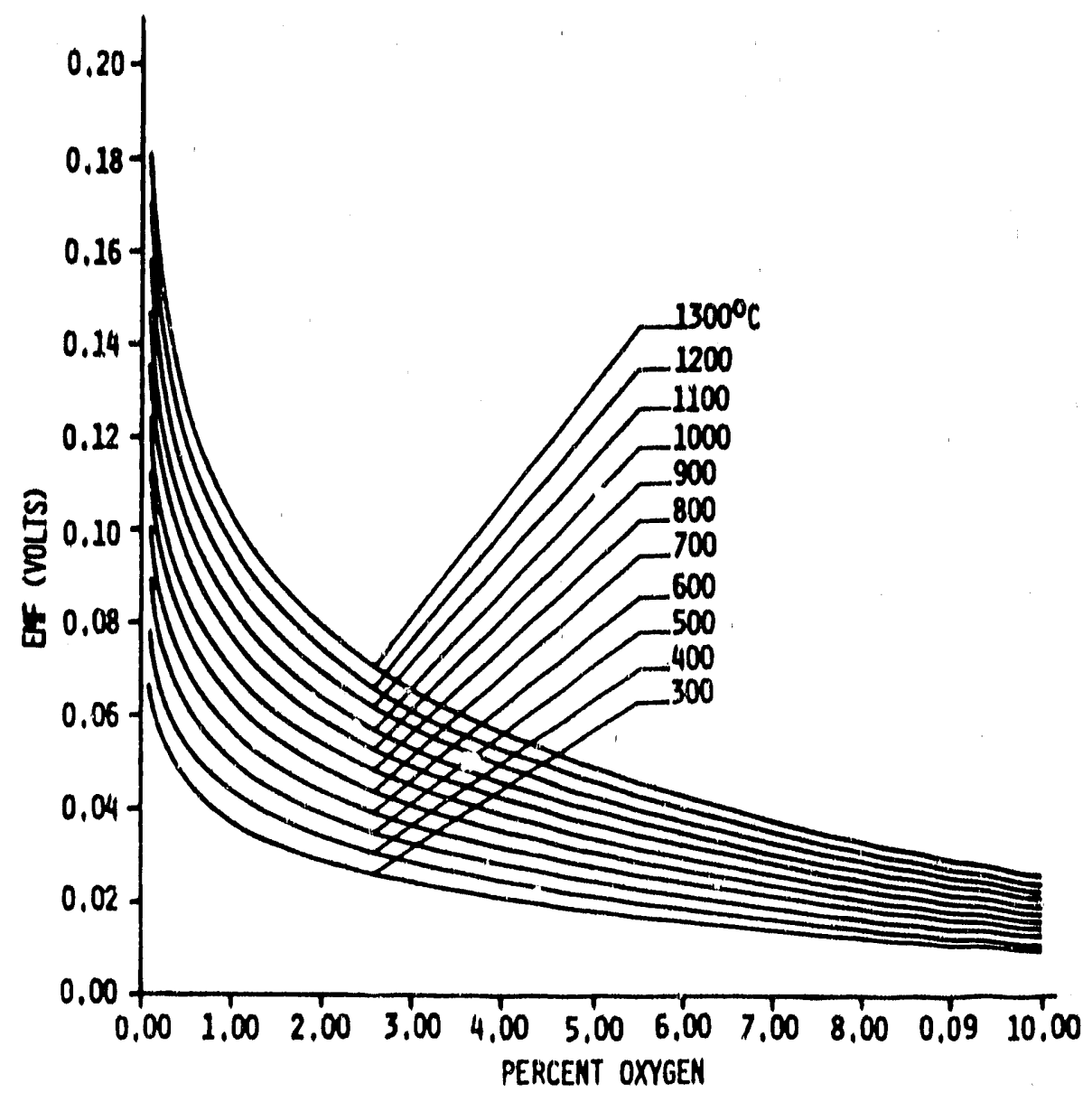

F1gure 2. Output Voltage of. Solld Electrolyte Oxygen Sensor. (From Ref. 3). 
Probes for measuring oxygen content in bollers for control purposes typlcally contain a thermostatically controlled chamber for the sensor and some means to ensure adequate flue-gas flow through this chamber. Detalls of commerclally avallable probes vary. In some systems flue gas diffuses tnto the sensor chamber through a porous medium. Others use the difference between gas stagnation and static pressure ("velocity head") to drive flue gag through the chamber. In some cuses an atr driven asplrator lo used to pull flue gas through the chamber, possibly through a coarse filter in dirty gas flows.

As the temperalure of the zirconiun oxide electrolyte is decreased, the conductivity drops and as a result the response time increases. At sensor temperatures below $900^{\circ} \mathrm{F}$ in automotive applications deposits foul the $z$ ircontum sengors. Over $1600^{\circ} \mathrm{F}$ sensors can suffer physical damage. For boller control applications sensor/s are typlcally heated to about $1200^{\circ} \mathrm{F}$.

Under lean conditions ( $3 \% \quad \mathrm{O}_{2}$ 1.e., greater than $16 \%$ excess alr) the output voltage of solld electrolyte sensors lo more sensitive to temperature changes than to changes in oxygen content. Several alternate approaches have been teveloped which increase the relative sensitivity to oxygen content. One such approach 1s termed "current mode" or Faraday type configuration. In this case an external vcltage is imposed on the zirconium oxide ce11, causing oxygen lons to be driven across the electrolyte. A diffuston barrier to placed between the flue-gas flow and the surface of the cell, which greatly linits the flow of oxygen to the surface. The driving voltage is meintalned high enough so that the oxygen partial pressure at the surface lo essentially zero. The current in the external clrcult is dependent upon the rate of arrival of oxygen at the surface.

The output current is 11nearly related to oxygen concentration in the exhaust by:

$$
I=4 \mathrm{FK}_{\mathrm{D}} \mathrm{P}_{\mathrm{e}}
$$

where:

$F=$ Faraday Constant

$K_{D}=$ Diffusion Constant for: Barrier

$\mathrm{P}_{\mathrm{e}}=$ Partial Pressure of Oxygen in the Exhaust Gas.

Unfortunately, the value of $K_{D}$ lo not independent of temperature but increases as $\left(\mathrm{T}^{0.75}\right)$ [5]. The net result relative to voltage mode sensors is increased oxygen sensitivity and reduced (but not zero) temperature sensitivity. An oxygen sensor for small heating bollers using this approach was developed in a prograin conducted by Brown Bover1 [6]. An orifice-type diffustion barrier was used in this design.

Another very interesting approach toward eliminating the temperature sensitivity has been developed by Franx $[7,8,9]$ (Elcoma Division of Nederlandse Philips Bedrigven B.V., Netherlands). The system uses a pair of solld electrolyte cells and an involved, cycle pumping method to eliminate the temperature sensitivity. Reportedly it is "ideal for... high efficiency selfcontrolling domestic oll fired and gas fired bollers" [8]. As discussed in the next sections of this report a prototype model of this sensor has been tested in this project. 
In the fourth method, semiconducting oxides are used as the oxygen sensor. These have a resistance which is dependent on the oxygen content of the surrounding gas. Sensors are constructed with a high surface area. (thill film or low density pellet) and are operated at fairly high temperatures $\left(1300-1650^{\circ} \mathrm{F}\right)$. The relationship between oxygen and resistance is given in [10]:

$$
R=R_{0} \exp \left[\frac{E_{A}}{K T}\right] \quad P_{e} e^{1 / n}
$$

where

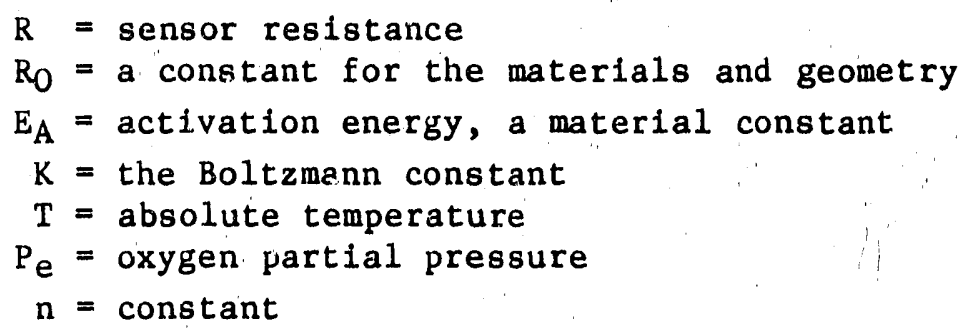

Like the zirconium oxide sensors this relationship also produces a large change near the stoichiometric ratio ("lambda jump"). Also, like the zirconiun oxide sensors the semiconductor sensors have a strong temperature dependence.

Several metal oxides have been used for oxygen sensing, particularly in automotive applications. The most popular is apparently tin oxide. Relative to zirconium sensors they are considered to be less expensive and less ciurable.

Ihokura, Tanaka, and Murakami [11] (Figaro Engineering Co., Japan) have reported on the use of a tin oxide sensor in a domestic gas heater. A small piece of the oxide was mounted on a ceranic substrate and platinum electrodes were used to connect with the two lead wires. The entire sensor, which is not temperature controlled measures $40 \mathrm{~mm} \times 6 \mathrm{~mm} \times 2 \mathrm{~mm}$. The sensor basically responds to the lambda jump and would shut off the heater in the event that a fuel rich condition occurred. The system was tested in a cyclic mode from 600 to $1800^{\circ} \mathrm{F}$ for 12,000 cycles and in a steady mode at $1750^{\circ} \mathrm{F}$ for 12,000 hours. No change in performance was noted.

\section{Carbon Monoxide Analyzers} methods :

Carbon monoxide measurement techniques include the following three

1. Infrared

2. Wet Electrochemical

3. Semiconductors

One of the most common methods of determining the carbon monoxide concentration in flue gas is by measuring the absorption of infrared light at a wavelength at which $\mathrm{CO}$ absorbs strongly. Extractive type infrared $\mathrm{CO}$ analyzers which must be fed clean, dry flue gas, are very widely used in laboratory 
applications. In situ analyzers are also avallable which measure IR absorption across the stack. These systems are generally very expensive relative to the small boiler market. Wet electrochemical systems are similar to the wet electrochemical sensors used for oxygen determination. Like the oxygen sensors they have the advantage of low first cost and the disadvantages of expendable cells and requiring extractive sampling.

Semiconductor devices are being used increasingly for determination of C0 and other reducing gases. When semiconducting oxides are heated to lower temperatures than used for oxygen retermination they can be used for CO measurements. At these low temperatures, oxygen cannot come to equilibrium with the bulk solid. Resistance is then affected by adsorption of gas molecules on the surfaces of cracks [10]. These systems are very widely used to detect gas leaks in homes in Europe and Japan. A semiconductor based Co detector which shuts down gas appliances when ambient $\mathrm{CO}$ exceeds $50 \mathrm{ppm}$ has recently received AGA approval. The manufactuier (Quantum Group Inc.) has recently reported on the development of a chemioptical device which might be used on heating equipment and cost less than current designs. An AC powered, celling mounted home detector for smoke and $C O$ is also available which uses a semiconductor sensor (BDC Electronics). This sensor can give false alarms due to non-CO sources like paint thinners. Use of these semiconductor sensors for flue gas would require flue gas extraction and conditioning.

\section{Smoke and Hydrocarbons Measurements}

In large bollers carbon monoxide measurements are of ten supplemented with smoke measurements in evaluating performance for control purposes. This typically involves the extinction of light across the stack (opacity). Direct application of this approach to residential oll-fired systems is not practical because the opacity at smoke levels that are generally accepted as excessive is still well under $1 \%$, which is difficult to detect accurately [1]. In reviewing alternative approaches for examining transient smoke, BNL has developed a multipass system for increased sensitivity [12]. A portable test set developed by Honeywe11 [13] for measuring smoke numbers in domestic oilfired equjpment used intensity of scattered light (as opposed to intensity of the main beam) measured with a photodiode detector. This appioach was selected over other alternatives (e.g. Ionfation). An extractive sampling system was used.

Any optical system of this type which might be used must include a means for compensating for variations in the source light and fouling of optical windows. These considerations could be the greatest factor in the final cost. At present a suitable system is not available commercially although the hasic technical feastivility is not at question.

For determining gaseous hydrocarbons, analyzers based on infrared light absorption are available. Like IR CO analyzers, these can be in situ or extractive and are likely to be prohibitively expensive. As a low-cost alternative, catalytic element sensors have also been developed. The sensor essentially consists of two resistance elements, often in a controlled temperature chamber. One of the elements is catalytic and experiences a tamperature rise related to the combustibles content of the surrounding gas. These elements 
are low in cost and are widely used for detecting combustible gases in confined spaces. These sensors have been reported to have limited sensitivity and stability and are not typically utilized in cuntrol applications.

\subsection{Optical Flame Analysis for Control}

In another approach the light emitted from a burner flame is measured in one or more flxed wavelength bands and this information is used for control. In a very rough sense it is an extension of the practical observation that rich flames are dull orange and lean flames are bright yellow. In this section, past work and commercial systems which have been developed are reviewed and their potential application to residential systems is discussed. This review serves as a background for some of the experimental studies described in subsequent report sections.

Radiant energy (light) emitted from. luminous oil flames can be considered as the sum of two contributions - a continuum which is related to black body radiation at the flame temperature and banded radiation due to specific gas phase species. Figure 3, adapted from Reference 14 (see also [15]) 111ustrates the differences between a luminous oll flame, a gas flame, a "blue" oll flame, and a black body in the ultraviolet (UV), visible, and near infrared (IR). The bulk of the energy emitted from oil flames is due to infrared radiation at longer wavelengths than shown in this figure. For the luminous oll flame, typical of a pressure gun burner, the continuum emission dominates. For the blue ofl flame and gas flame, which are not luminous, the relative importance of the banded radiation is increased.

Developinent work on an optically based air/fuel ratio controller was performed at the University of Sheffield [16]. The approach which was developed in this work was later commercialized by the Land Co. [17]. The method takes advantage of the observation that the itensity of infrared radiation peaks near the stoichiometric air/fuel ratio. Initial work done at the University of Sheffield involved gas burnecs. Only narrow band radiation at wavelengths around 4.3 and 2.7 microns was used for control. Note -1 micom $=1000$ namoineters (nm). The 4.3 micron band is primarily $\mathrm{CO}_{2}$ radiation and the enission at 2.7 infcrons is due to both $\mathrm{CO}_{2}$ and $\mathrm{H}_{2} \mathrm{O}$. In later tests with larger burners a very broad wavelength band in the infrared was used for control. This involved an unfiltered lead sulfide detector having a response in the range 1-3.5 microns. In the control application the burner air/fuel ratio is modulated continuously about $1-2 \%$ to ensure that the mean air/fuel ratio corresponds to the radiation peak. The University studies also included a domestic warm air furnace and small $(75,000 \mathrm{Btu} / \mathrm{Hr})$ kerosene heater. The system reportedly worked well although the data taken was not nearly adequate for the interest of this report. This system has reportedly been applied to larger boilers with success and is currently commercially avallable. Attempts to apply the systern to smaller bollers were not successcul because the peak emission was associated with excessive smoke and occurred over a wide air/fuel ratio range.

In a more recent program optical control of air/íluel ratio for residual oil flanes was studied by MIT, sponsored by 5 utility companies [18]. As a part of this program the commercial Land "peak seeking" control system was tested. The sensor in this commercial system detects light in a wavelength 


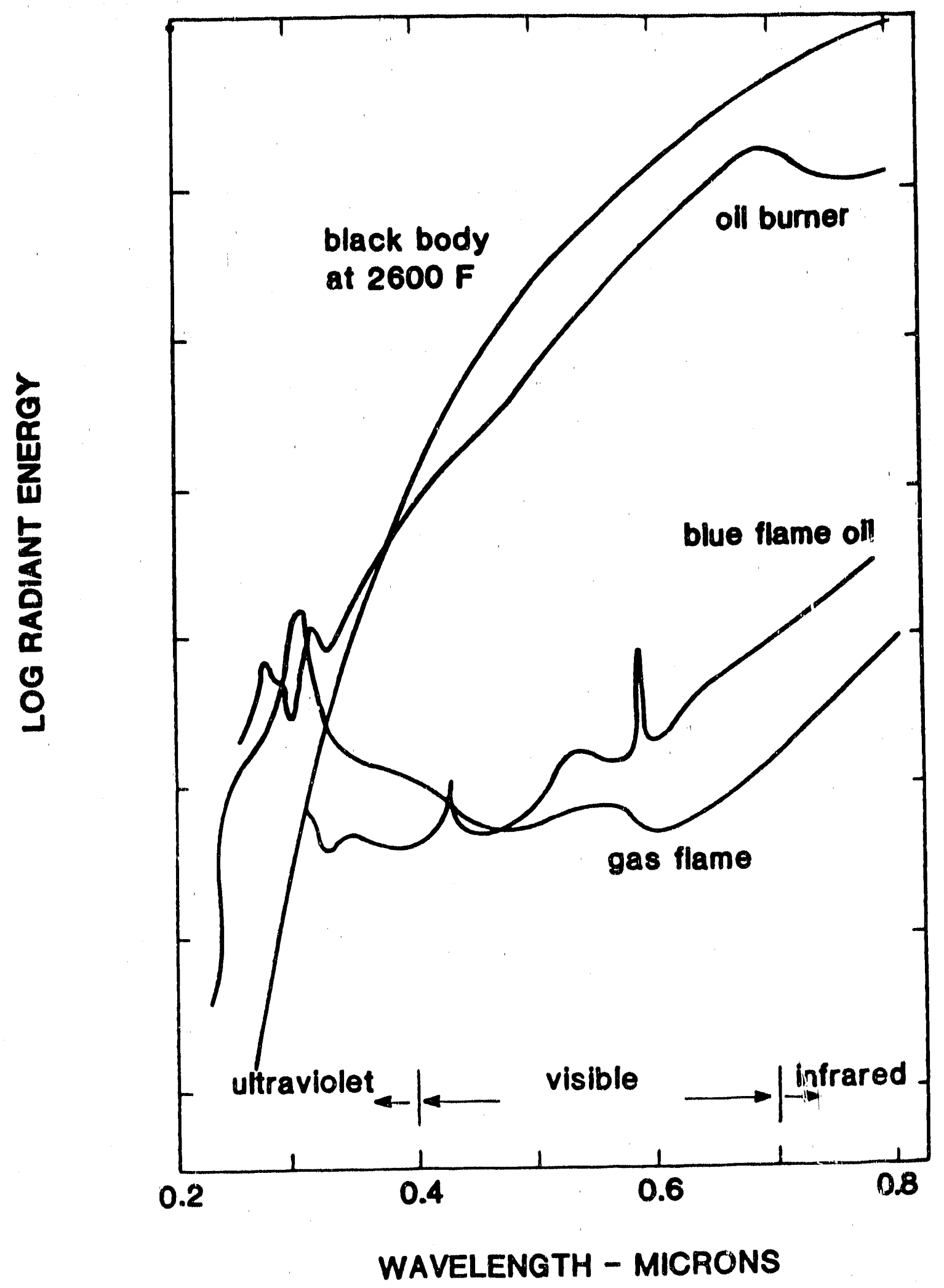

Figure 3. Comparison of Flame Emissions.

(Ref. 13). 
band which 18 fuel dependent. For gas the sensor responds to radiation in the infrared while for oll a sensor which primarlly responds in the visible is used. The peak seekling aystem was found to perform adequately in general but was adversely affected by a large change in flame pattern. As a part of the MIT program detailed emission spectra was obtained for 6 oll flames in the UV, visible, and IR. An einlsaion peak due to the hydroxyl group, $O H$, in the UV (.310 microns or $309 \mathrm{~nm}$ ) as measured from the flame front region was found to vary atrongly with alr/fuel ratio. It was concluded that broad band ( 1.0 . peak seeklng) methods might be improved by also examining some narrow band elnissions from some gas phase spectes like OH.

An optical control system, which incorporates some of the conclusions of the MIT prograin has been developed by the Thermo Electron Corporation. This system has recently been tested on a $360 \mathrm{MW}$ coal fired utility boller [19]. Termed Spectral Fuel Analyzer (SFA) it is a modifted version of an earlier system developed by Environmental Data Corp. (EDC), now a part of Thermo Electron. The older EDC system used as input two selected IR band signals. The SFA in contrast reads specific emissions from $\mathrm{OH}$ and $\mathrm{CH}$ in the $\mathrm{UV}$ and $\mathrm{CO}_{2}$ and "background" in the IR. The utility boller tests reportedly showed that the SFA could meet 1 ts measurement objectives. It was not apparently tested in a control inode. Presumably in a control mode the alr/fuel ratio for each burner in a large boller would be adjusted to give constant ratios of the specific gas species emissions to the background. Following these utility buller tests additional development and further tests on a smaller package boller were done under sponsorship of the U.S. Department of Energy. Generally 1 t was concluded that the system was useful for burner diagnostics but could not be used for quantitative deterinination of air/fuel ratlo under conditions of vartable load and vurner swirl [20].

The Babcock and W1lcox Co. has recently reported [21] on the development of an optical system for on-line monttoring of pulverized coal- and oll-fired utility bollers. The system uses the ratio of emitted light intensity at two specific wavelengths to determine flame temperature and intensity. Fiber optics are used to obtain this information at up to 30 locations throughout the furnace. An optical alr/fuel ratio control system has recently been patented for internal combustion engines [22]. A fiber optic cable is used to transmit light from the combustion chamber to the detectors.

The "peak seeking" approach for control of industrial burners which fire natural gas has also been used in a recent project sponsored by the Gas Research Institute and performed by the United Technologies Research Center [23]. A lead selenide infrared detector was used in this project. While the basic control concept used in this work is not novel, the implementation details are. 


\section{EXFERIMENTAL APPARATUS AND MEASUREMENTS}

\subsection{Heating Equipment Used}

Boller tests for studies on flue gas temperature and Co/smoke relationships were done using a cast tron section-type boller (Peerless Heater Co. Model NO-JOT-35-SPT) fired with a high-pressure retention-head burner (Beckett Model AFG). Furnace tests for these same studies were done using conventional "low boy" warm-alr furnace (Rheem Alr Jonditioning Division Model ROH2 120A) fired with a conventional retention head burner (Beckett Mode1 AF).

Both units were installed in test stands at the BNL Combustion Equipment Technology Laboratory. The boller water is clrculated through a water-to-alr heat exchanger which simulates a domestic heating load. The heat exchanger is equipped with a variable-speed air fan for load modulation, and heated alr 1s discharged to the outdoors. Water temperature at the boller inlet and outlet are accurately monitored. The burner can be operaced in a fixed cycle mode or i.t can operate under the control of the boller water temperature controller. The boller, as installed for these tests did not have a domestic water coll.

In the furnace stand the standard blower is removed and air is supplied through a measurement/conditioning train. This set-up serves to heat the alr to any desired temperature. Air mass flow rate ls measured using a vortex shedding flowmeter. Thermocouple grids in the alr inlet and outlet plenum are used to accurately measure these temperatures.

Some limited data were also obtalned using a prototype condensing warm air furnace. This furnace is fired with a retention head burner and has a secondary air-to-alr heat exchanger added to an otherwise conventional furnace to reduce the flue gas temperature to about $100^{\circ} \mathrm{F}$.

Most of the experimental studies on oxygen sensors emlssions were done using a conventional retention head burner (Beckett Corp., Model AF) firing into a dry base, steel boller (Burnham BB0111.FR)" Some additional tests of a zirconium oxide oxygen sensor were done using a prototype prevaporizing oll burner fired Into a wet base, cast. Iron boller (Peerless Heater Company Mode1 JOT-35-SPT). The prevaporizing burner has been developed by Foster Miller Associates and a description can be found in reference 24 . This burner was of interest because it can operate at excess air levels much closer to stolchio. metric where zirconium oxide sensors are more sensitive.

Some of the optical studies were done using the conventional retention head burner fired into the dry base steel boller described above. In addition, some data was taken using a wet base, two pass boller with a horizontal, cylindrical combustion chamber (Thermodynamics Boller Co. Model \# 100). This unit, which is shown in cross section in Figure 4, is very wel1 sulted for the purposes of this project It provides a water cooled combustion chamber with an easily removable refractory liner and a rear cover which can be easily modified fni: probe access to the combustion chamber. With this system optical measurements were made with viewpoints both ahead of and behind the flame. 


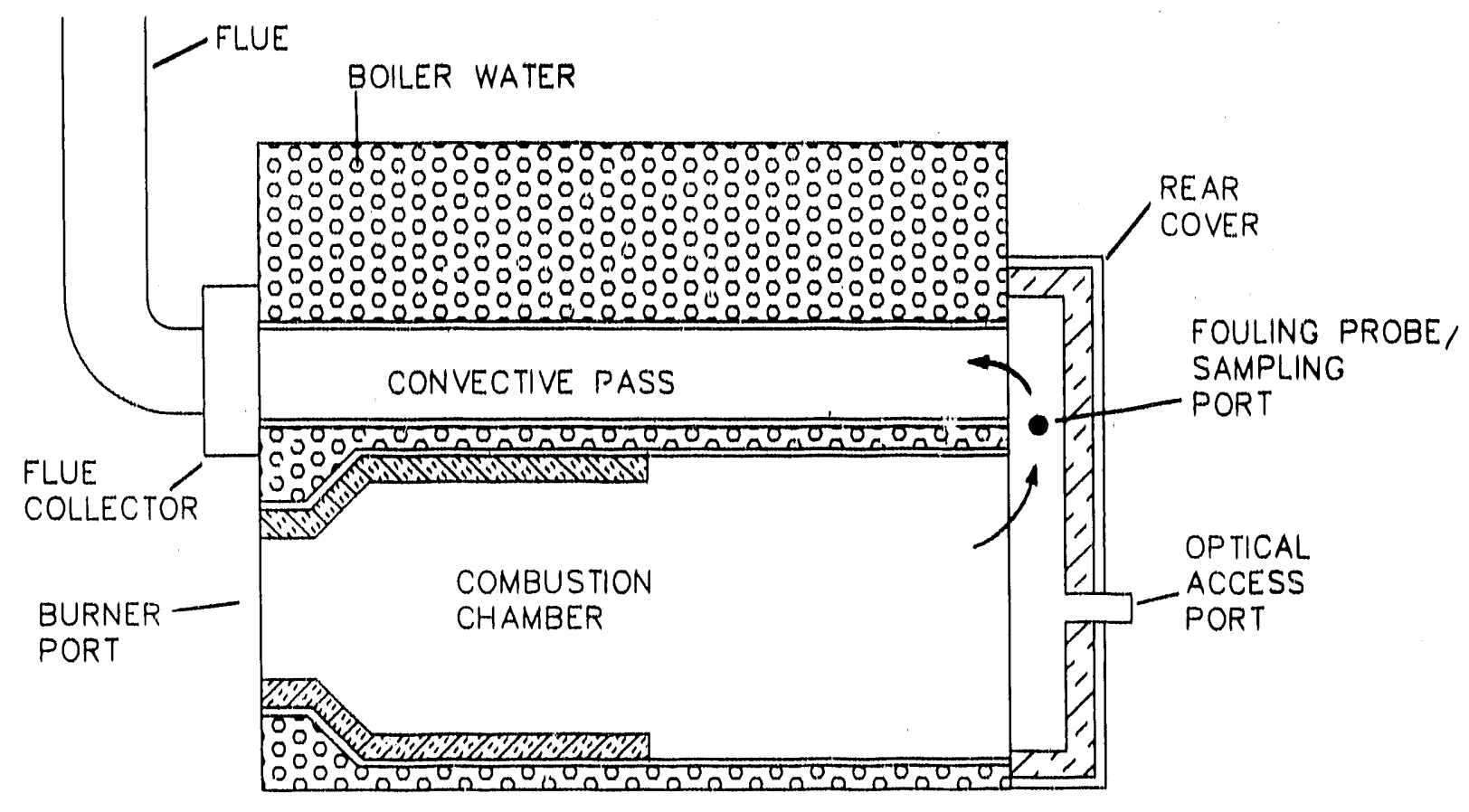

Figure 4. Cross section 1llustrating wet base, two pass boller used for optical studies. 
In addition to the conventional retention head burners, optical emiaston measurements were made using one alr atotnized burner which lo currentily being marketed In Europe. (Alrtronlc Mode1 - Bentone/Electro 011, Sweden [25]). This to a very unfque system which uses the externalily atomlzed "Bablngton" nozzle $[26,27]$.

\subsection{Gas Analyolo Equipment}

Flue gas oxygen content, for excess alr determination, was measured using a paramagnetlc analyzer (Beckman Model 755). Flue gas carbon monoxide content was measured using an infrared analyzer (Beckman Model 865).

For most measurements flue gas samples were extracted from the stack using a stainless steel probe and heated sampling 1ine. The gas sample was conditioned using a refrlgeration drier before feeding to the analyzers. For some tests gas samples were extracted directly from the combustion chamber. The jampling train used for these measurements is lllustrated in Flgure 5. The sanpling probe to water cooled to protect ti from overheating and to irinibit gas phase reactions (specifically $C O$ oxidation) from occurring in the sampling system.

\subsection{Oxygen Sensors Tested}

Three zirconium-oxide oxygen sensors were tested during this profect, a commercially avallable system produced by Nederlandee Phillps Bedrifven, B.V. (Netherlands), a typlcal unheated automotive type sensor, and a heated automotive senoor.

The Phillps undt was loaned to BNL for this profect by Amperex Electronic Corp., a North American Phillps Company. Relative to other zirconfum oxygen analyzers which are commercially avallable, this untt was of particular interest because the manufacturer has used it on small commercial bollers and has been pursuing the development of a low cost unft for domestic heating applications [8]. The unit tested during this program lo essentially the larger unit used in Europe modifled for 60 cycles, $110 \mathrm{v}$ operation. The tested sensor system consists of two parts, a stack probe and a control/readout unit. The sensor is located in the tip of the electrically heated stack probe and consiats of two zirconium oxide disks separated by a small hermetically sealed chamber. As discussed in Section 2 of this report, this analyzer uses a unique cyclic pumping method to eliminate the temperature effect on the signal. The control/readout untt displays the partial pressure of oxygen in the flue gas.

The sensor which has been developed by Philips for residential applications is slgnificantly smaller than the one tested $(17.5 \mathrm{~mm} \times 10 \mathrm{~mm})$ [8] and reportedly could market for 1 ess than $\$ 75.00$ in large quantities, including the control clrcultry for the sensor [28].

In automoblles, unheated-type oxygen sensors, are installed close to the engine's exhaust manifold and rely on exhaust heat to bring the serusor temperature above the point at which the zirconium oxide has a reasonable conductiv1ty. The temperature of the untt changes with engine load and the sensor can only be used in the "lambda jump" mode to control alr/fuel ratio very close to stolchionetric. 


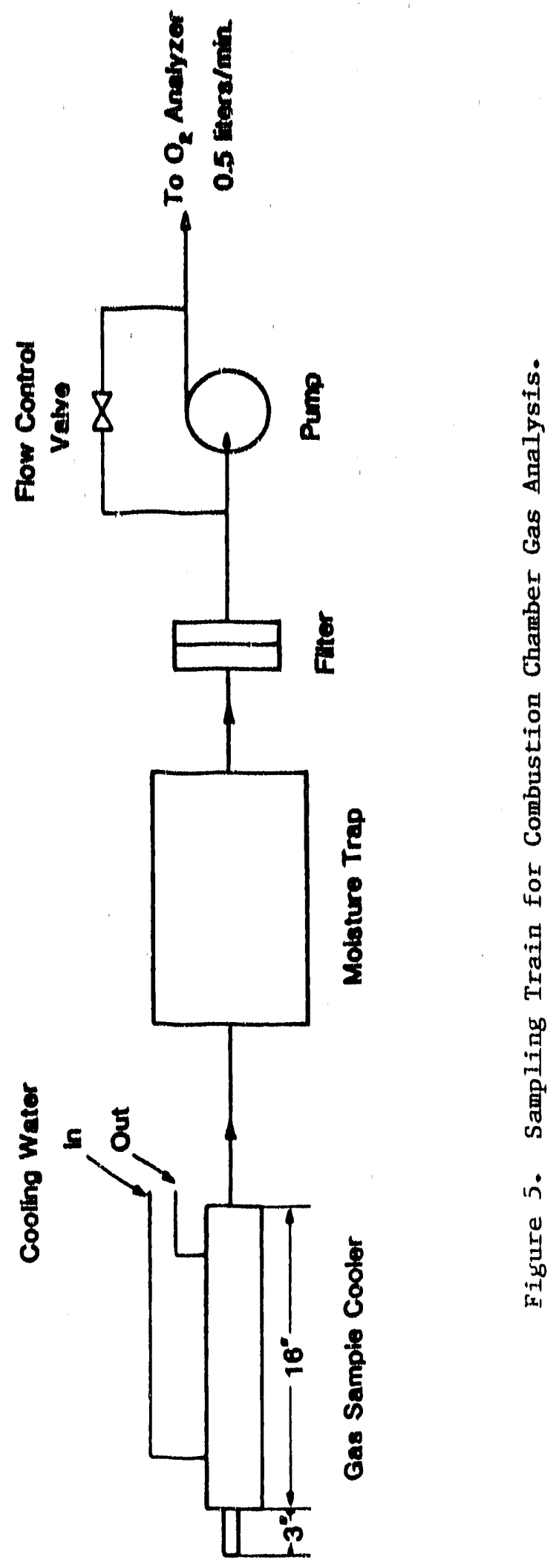


In the case of the newer lieated type und the posttive temperature coefflctent electrical heating element malntalns the zlicondum oxide in ito high conductivity teluperature range. Reported advantages of using the heater include fagter warmups, reduced difflculties due to upsets (a.g. water hitting sensor), and the ablitty to use only one sensor with a $V-8$ tiype englne. Like the unheated sensor the heated untt lo used only in the "lambda Jump" mode.

To utilize an unheated type oxygen sensor in a realdential syatem it must be located in a place where it w111 be heated to 900-1600 $\mathrm{F}$. To achieve this the sensor was located in the upper regton of the refractory combustion chamber of a dry base ateel boller. The aensor was mounted through the center of a refractory digk $0.5^{\prime \prime}$ thick and $3.5^{\prime \prime}$ in dianeter. This disk was then placed In the "vlew port" cut out of the boller's combugtion chamber. Flgure 6 1Llustrates the location of the sensor in the chamber and Elgure 7 111ustratea the sensor ln the rellactory digk. The center line of the oxygen sensor was $6 "$ to the right and $6 "$ above the burner centerline. A thermocouple $\left(1 / 16^{\prime \prime}\right.$, type $K$, inconel sheath) was also passed through the refractory disk to measure the yas temperature adjacent to the sensor. Firing at $0.75 \mathrm{gph}$ the temperature was measured to be about $1200^{\circ} \mathrm{F}$, which 1 s ldeal for the zitrcuntum sensor. The heated type automotive sensor was located directly in the flue plpe for testing. A thermocouple was attached to the outer sheath of the sensor and temperature was controlled by varying the heater supply voltage over a range froin 8 to 22 volts.

\subsection{Optical Lmisaton Measurements}

In this program detalied flame optical emisolons were measured, primarily from a line-of-site within the burner alr tube close to the centerline. Thio was done, as opposed to adding geparate vjewports through the combustion chainber because of two pracitical constderations. Flrgt, optical gengors lin the buiner housing are cooled and kept clean by combustion adr while separate ports would require an additional purge alr system. Second, in the restdenthal heating aquipment Industry, burners and bollers or furnaces are not lntebrated but are produced by aeparate manufacturers. A burner control aystem, which requitres access ports in the boller or furnace in which the burner is filred would be lese practical than one incorporated in the burner package.

Optical ineasuremente made during this program included 1) spectral intenoltieg over the range 200 to 1100 nin and 2) broadband entastons. In opectral. measuremente Intens l:y lo meagured at many different wavelengthe, with a narrow bandpass monochrometer. The broadband measurements, in contrast, are inade wlth a gensor which responds over a broad apectral range and a monochrometer was not used. T'o lmplement the spectral measurements, a fiberoptic cable or liquld light gulde was used to bring the light olgnal to an external. monochroneter and detector. 'this arrangement to lllustrated in Figure 8. The broadband embaton measurements lnvolved plactng the optical gensore direcily In the combugtion tube. These seneors then responded to light over their entire wavelength response range.

The glase flber optice cables used have a bundle diameter of $1 / 8$ inch and a length of 24 inches. These have good transmlgaton over the wavelength range $380-1300$ nin. The Liquld Light gulde was used in place of the glase fiber optic cable to extend the apectral measurements further into the altraviolet. The light guide hass a case dianeter of 0.197 Inches, a length of 39.4 dnches and good transmisston over the range from 200-720 nin. The grating monochromaLor used to a $1 / 8$ meter, in-line off axts bbert conf Lguration wilh a maxtmum 


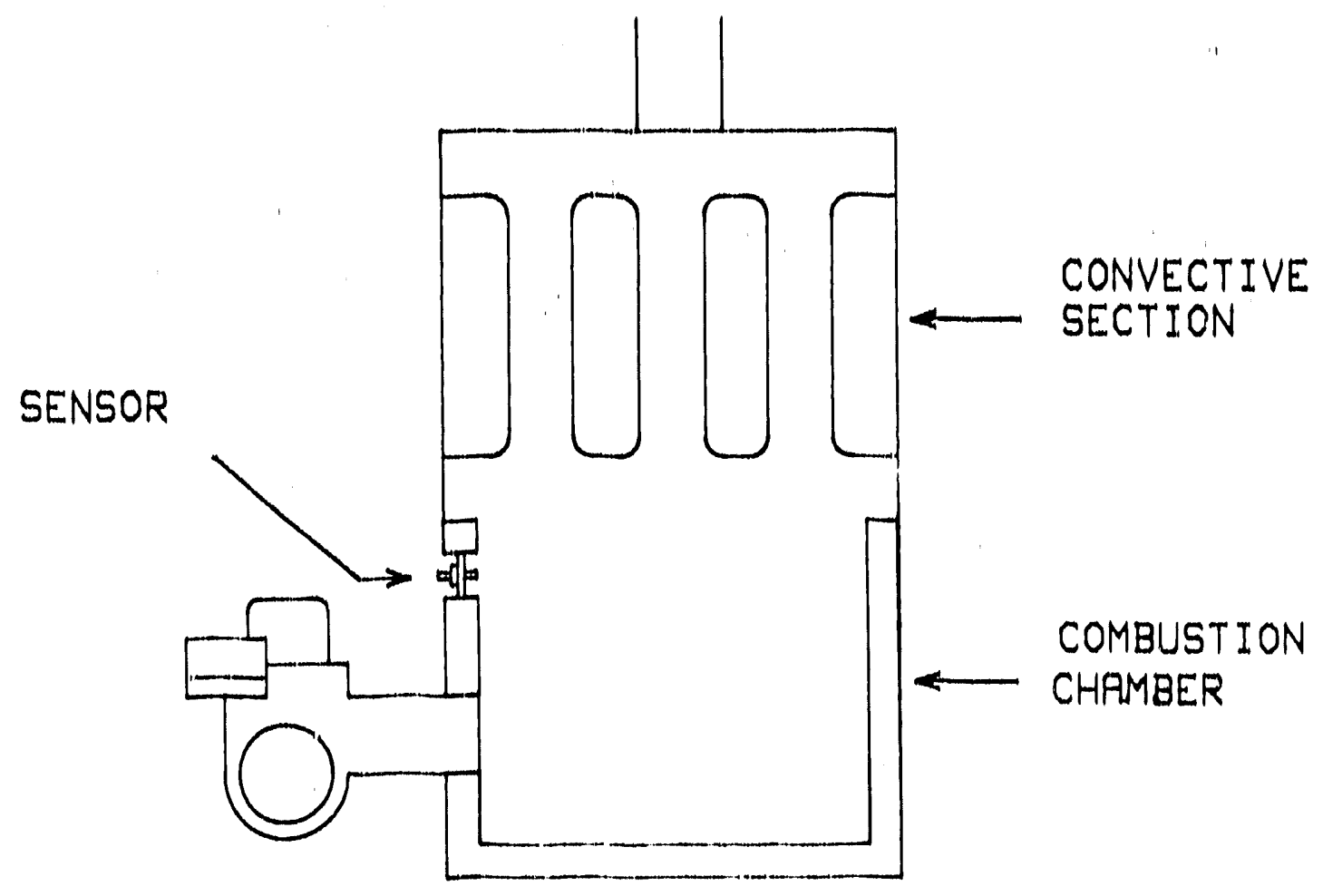

Plgure 0. Illustration of the location of the unheated automotive type oxygen sensor in the combustion $c$ hamber. 


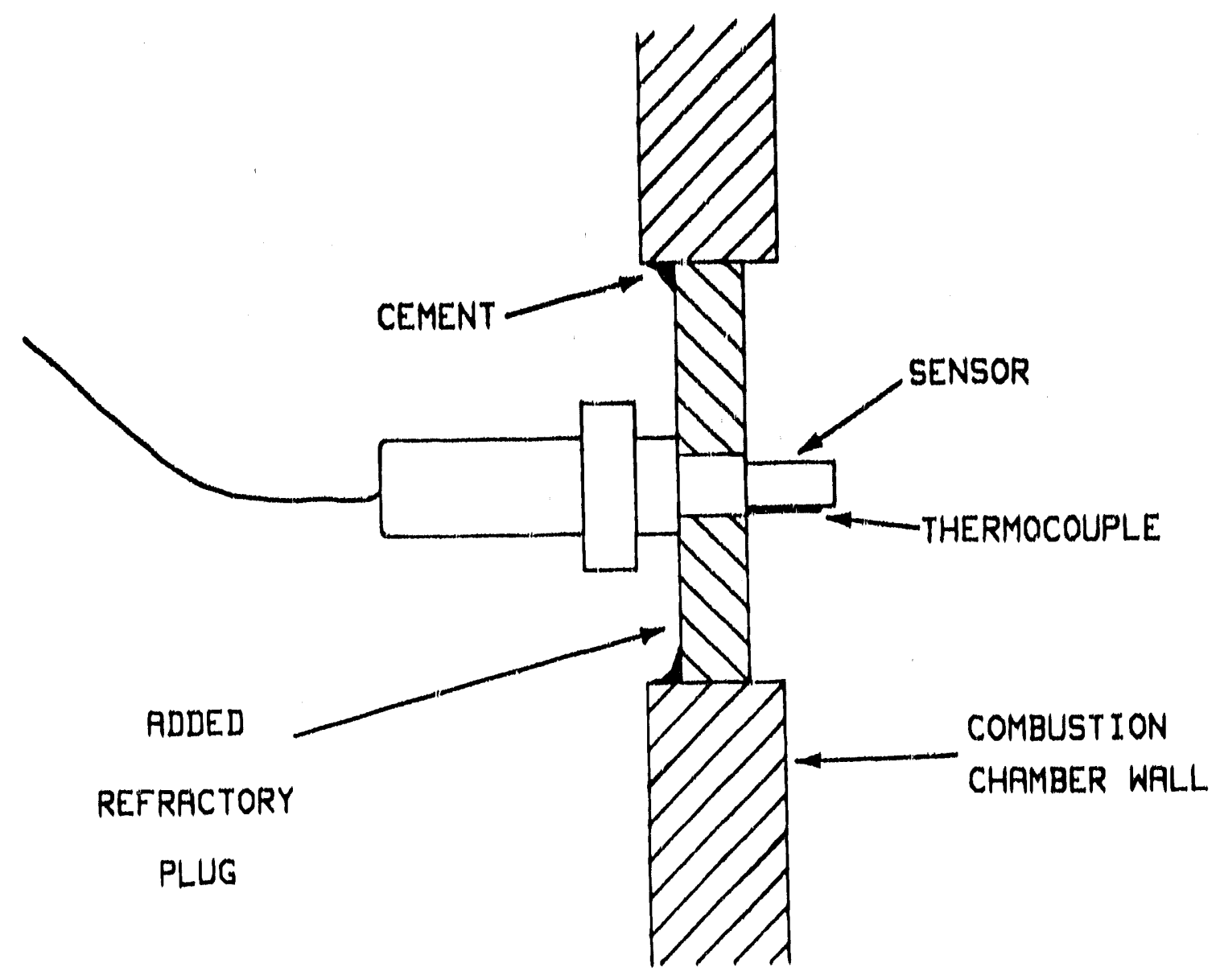

Figure 7. Detalls of the installation of the unheated automotive oxygen sensor in the combustion chamber. 


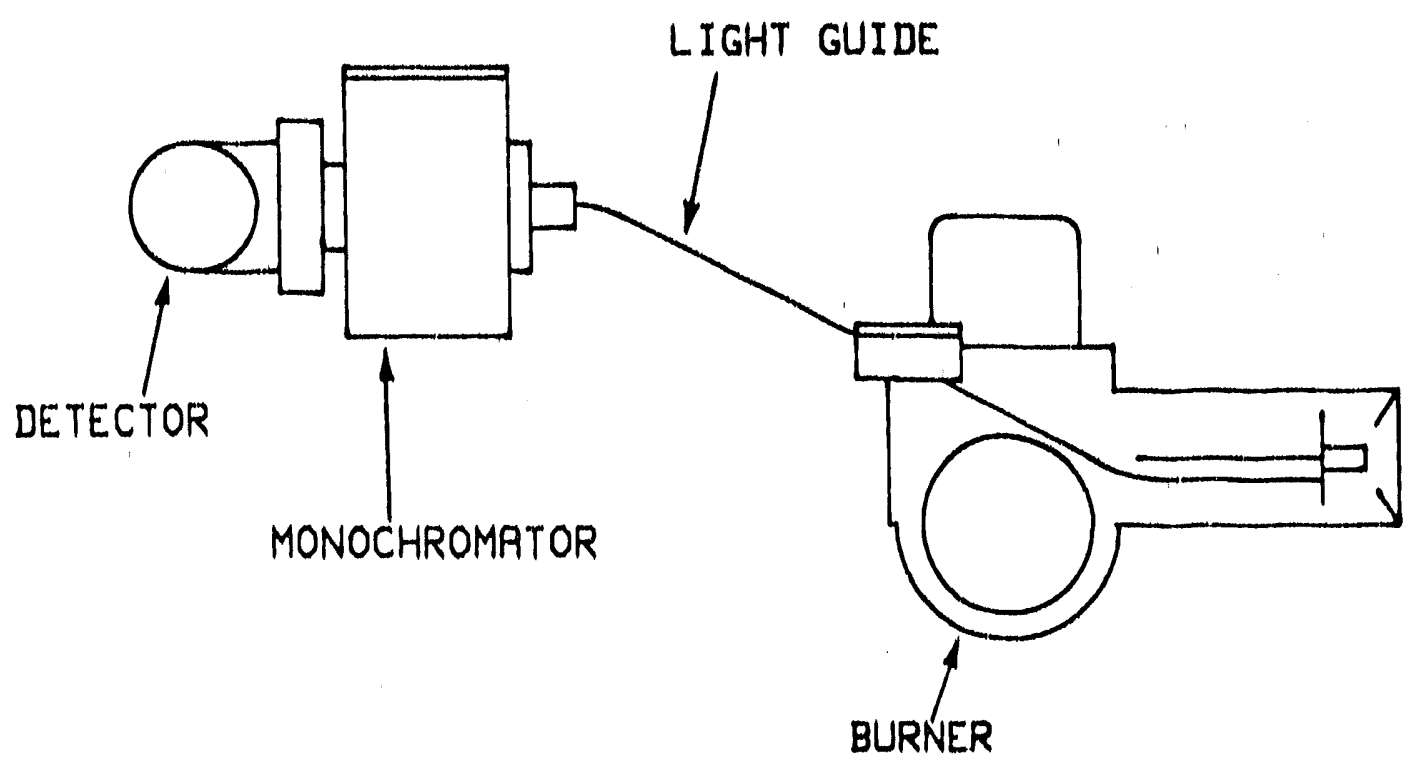

Figure 8. Opt 1cal Arrangement for Spectral Intens1ty Measurements. 
resolution of $0.5 \mathrm{~nm}$ (Oriel Corporation, model 77250). The monochrometer silt width was generally adjusted to give the maximum resolution possible for each grating consistent with the detector sensitivity. Gratings were used with groove spacings of 2400,1200 and 60011 nes $/ \mathrm{mm}$. These have useable wavelength of $175-500 \mathrm{~nm}, 175-700 \mathrm{~nm}$, and 600-2000 nm, respectively. Two detectors were used alternatively at the monochrometer outlet, a silicon photodlode (OrLel Corporation Model 7182) and a photomultiplier (Orlel Corporation Model 77340). The range of spectral response to 300 to $1100 \mathrm{~nm}$ for the photodlode and 200 to $700 \mathrm{~nm}$ for the photomultiplier.

Senoors used for broadband emiasions include a cadmlum sulfide photoconductor ("cad cell"), a lead selenide ( $\mathrm{PbSe}$ ) photoconductor, and a slmple thin foll thermocouple. The cad cell used is the type commonly used for flame proving in oll burners and for the purposes of these studies was located $\mathrm{in}$ its normal position, adjacent, to the transformer. The PbSe cell (Hamamatau Corp. - P791) responds to infrared radiation primarlily in the wavelength range from 1500 to $6000 \mathrm{~nm}$. The thin foll thermocouple was installed as a very low cost pyroelectric type sensor and will respond primarily to IR radiation. Figure 9 lllustrates the location of the $\mathrm{PbS} \exists$ sensor in the burner alr tube. This sensor was simply mounted through the support plate which is $23 / 8$ inches frow the nozzle tip. The centerline of the PbSe sensor was $3 / 4$ inches from the nomzle centerline. At this position the sensors view of the flame is partially blocked by the slotted retention ring. The thin foll thermocouple and the end of the fiber optic cable. (or light guide) were essentlally adjacent to the PbSe sensor and also $3 / 4$ inches from the nozzle centerline (note - these sensurs are not shown in Figure 9).

In optical systems as used in these studies each system component has a unique wavelength dependent transmission or sensitivity. To allow output signals from the spectral intensity measurements to be converted to a meaningful numerical scale, calibration of complete systems was done using a "standard" tungoten-halogen light source. Detalled callbration of the broadband sensor was not done and results are reported in terms of resistance for the photoconductors and temperature for the thin foll thermocouple. An approximate calibration done using the tungsten-halogen 11ght and the cad cell indicates that resistance is roughly related to intensity (over the range of interest) by:

$$
\text { Resiotance a (Intensity)-1/2 }
$$

It ts this relationship that allows relative intenglty to be inferred from measured reststance.

\subsection{Suction Pyrometer.}

T'o compliment the measurements of flame optical emissions some measurement:s of temperatures along the center line of the combustion chamber of the boller 1llustrated in Figure 4 were made using a radiation shlelded suction pyrometer. This was constructed using an uncooled ceramic tube with a radiation shield attached to the front. This shield is a ceramic tube and small ceramic spacers held the two tubes concentric. Temperature was 


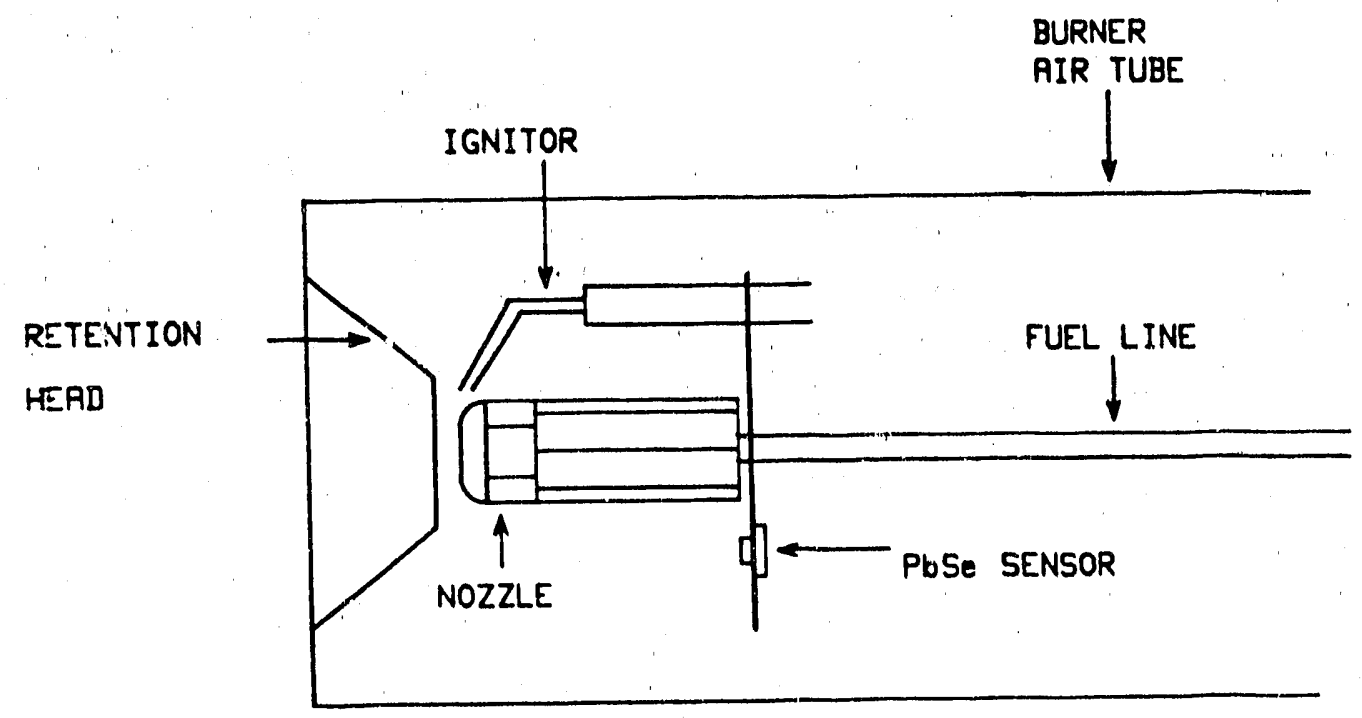

Figure 9. Location of PbSe sensor in burner air tube. 
measured using an exposed junction", type $S$ thermocouple (AWG 30) located in the center tube within the radiation shield. Outside of the boller the probe was connected to an air coolex, a condensate trap, and a sampling pump. The gas flow rate through the pyrometer was about 1.0 standard cubic feet per minute. At this rate the measured temperature is estimated to be $40^{\circ} \mathrm{F}$ (or less) lower than the actual gas temperature. This is based on comparison with calibrations for pyrometers of similar design [29]. 


\section{RESULTS}

\subsection{C0/Smoke Relationship}

In Figures 10 and 11 , measured smoke numbers and flue gas $C O$ contents over a range of excess alr levels are shown for the cast iron boller at two firing rates. Comparison of these figures shows that smoke is produced at higher excess alr levels with the lower firing rate. This is a very typlcal behavior resulting from reduced head pressure drop and turbulence with the lower afr flows at the lower firing rates.

The data at $0.65 \mathrm{gph}$ was taken up to very high excess air levels. It is interesting to note that there was no significant $C O$ at these high alr flow levels. This is in contrast to earlier studies which indicated high CO at both very low and very high excess alr levels. In none of the tests performed during this progran was $C O$ produced at high excess air. It is expected that at some extremely high excess air level, CO would be produced because of flame quenching, but these results indicate that this excess air level may be too high to be practically reached. High excess air $\mathrm{CO}$ could be a concern in $\mathrm{CO}$ based control. A system which senses $C O$ and increases excess air in response would fail if that $C O$ was being produced in the high-air-flow limt.

The data in figures 10 and 11 indicate a reasonably good agreement between smoke and $\mathrm{CO}$. In Figure 12, $\mathrm{CO}$ and smoke data obtained over a range of excess air levels is shown for the condensing warm air furnace. In this case smoke clearly "leads" $\mathrm{CO}$ as the excess alr is reduced. A control system which relies on high $C O$ to indicate poor combustion would not be practical in this system. Results with the conventional (non-condensing) furnace are shown in Figure 13. In this case smoke again leads $\mathrm{CO}$.

Carbon monoxide and smoke are both products of incomplete combustion, and so it is expected that a low quality flame could generate both species. Available infurmation on the kinetics of CO oxidation, however, indicates that it oxidizes rapldly relative to soot in flue gas with typical residual oxygen levels. A flame which is producing high smoke may also be producing high $\mathrm{CO}$ but the $C O$ may be oxidized before reaching the flue plpe. Carbon monoxide measured closer to the flame zone, then, may be a better Indfcator of a poor quality flame. To evaluate this, CO measurements were made inside of the combustion chamber of the boller. The water cooled sampling probe used for these measurements was described in Section 3.

Figure 14 illustrates the approximate location of the two sampling points. One location was in the upper portion of the combustion chamber well beyond the flame zone. The other sampling point was just beyond the visible flame zone. Figures 15 and 16 show the sampling results for both locations. In all cases the smoke number was measured at the flue. In general, as the sampling point is moved closer to the flame, the $C 0$ levels rise and the excess air level at which $C O$ begins to become significant increases. It should be noted that the excess air level corresponding to a number one smoke is not significantly different $w_{\text {. }}$ :h the cooled probe in the chamber. The probe, then, is not affecting the flame quality greatly. Figure 17 shows the CO 


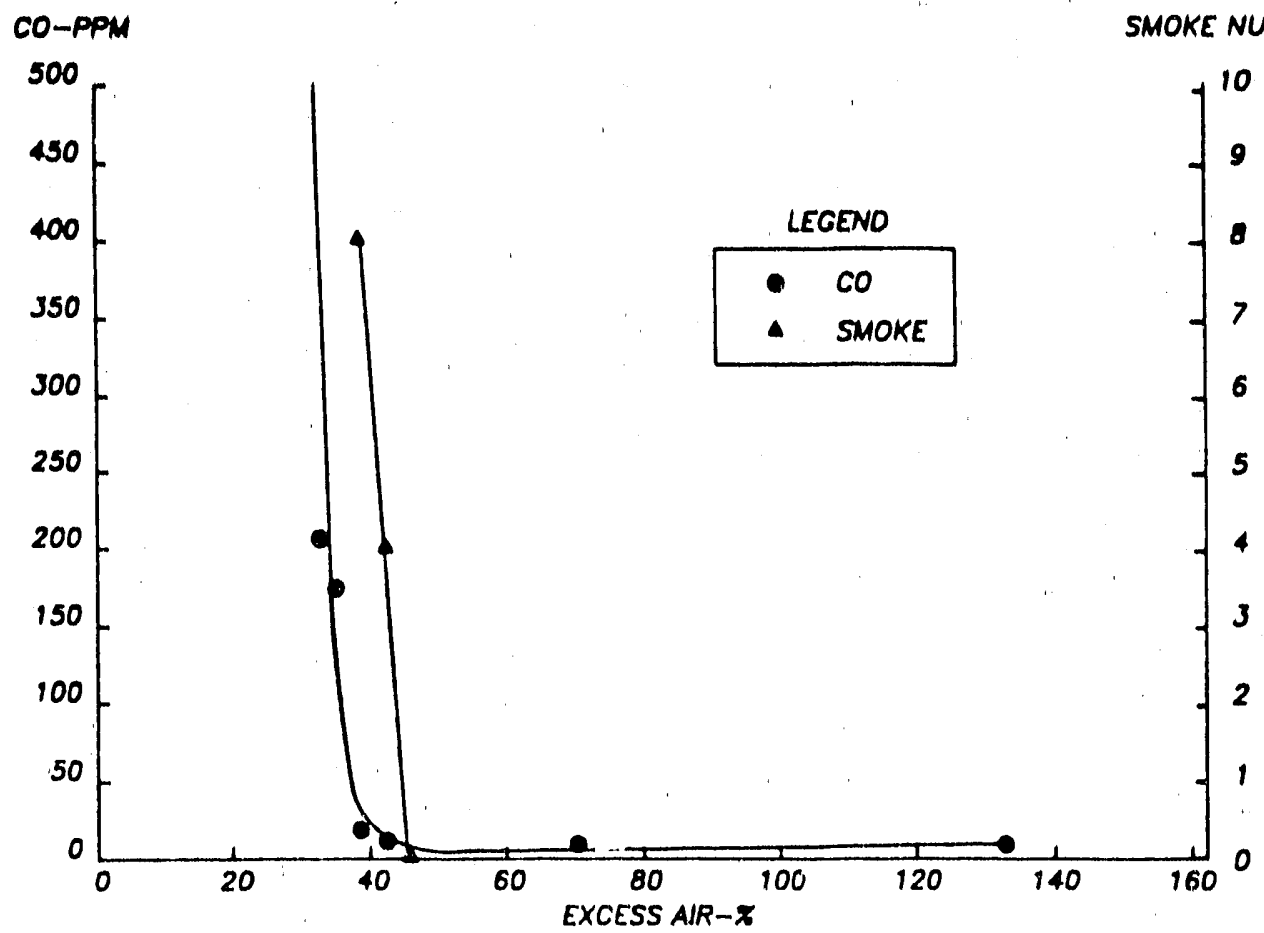

Figure 10. Measured smoke number and $\mathrm{CO}$ emissions over a range of excess air levels. Hot water boller, $0.65 \mathrm{gph}$.

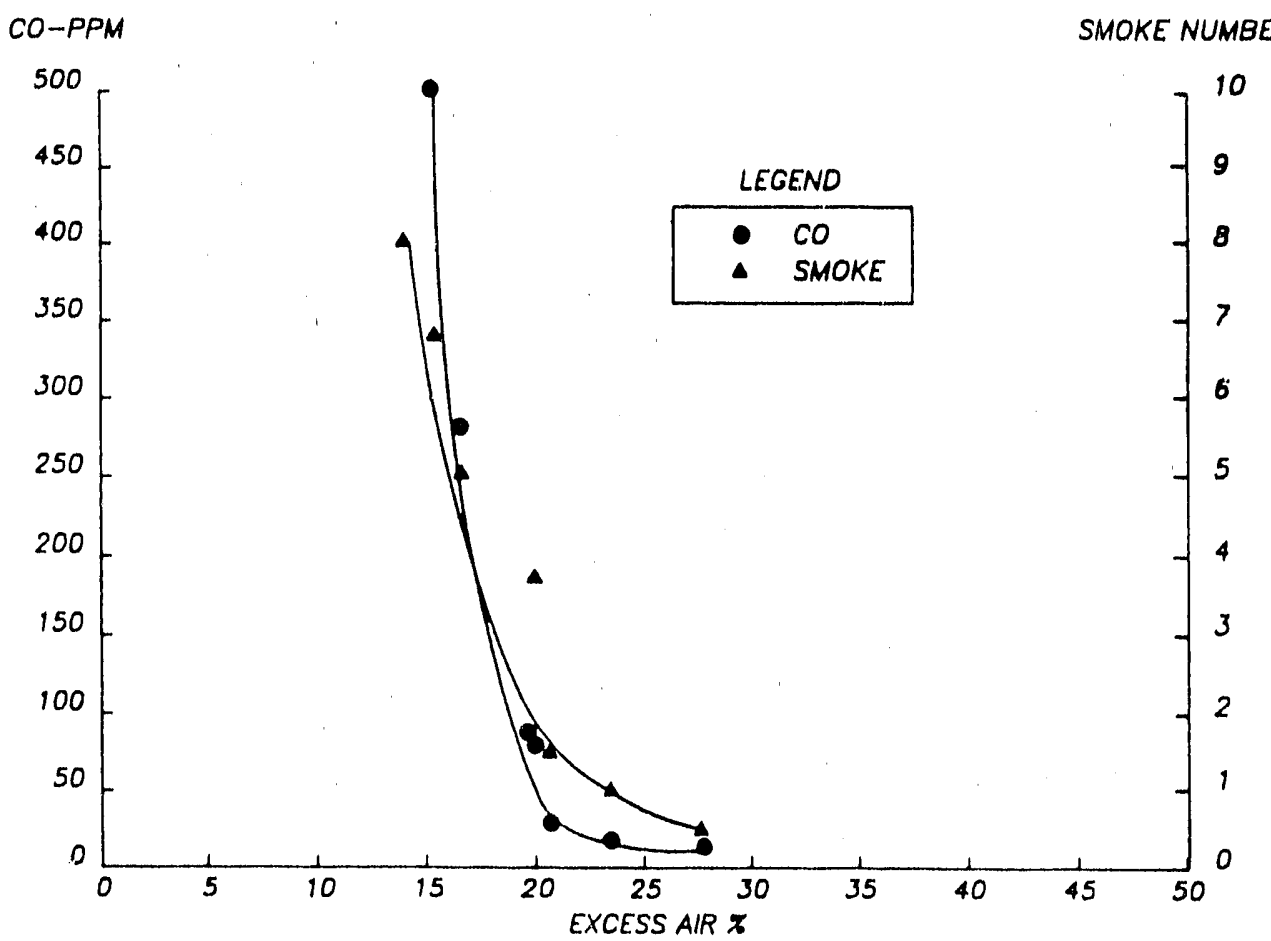

Figure 11. Measured smoke number and $\mathrm{CO}$ emissions over a range of excess air levels. Hot water boiler, $1.00 \mathrm{gph}$. 


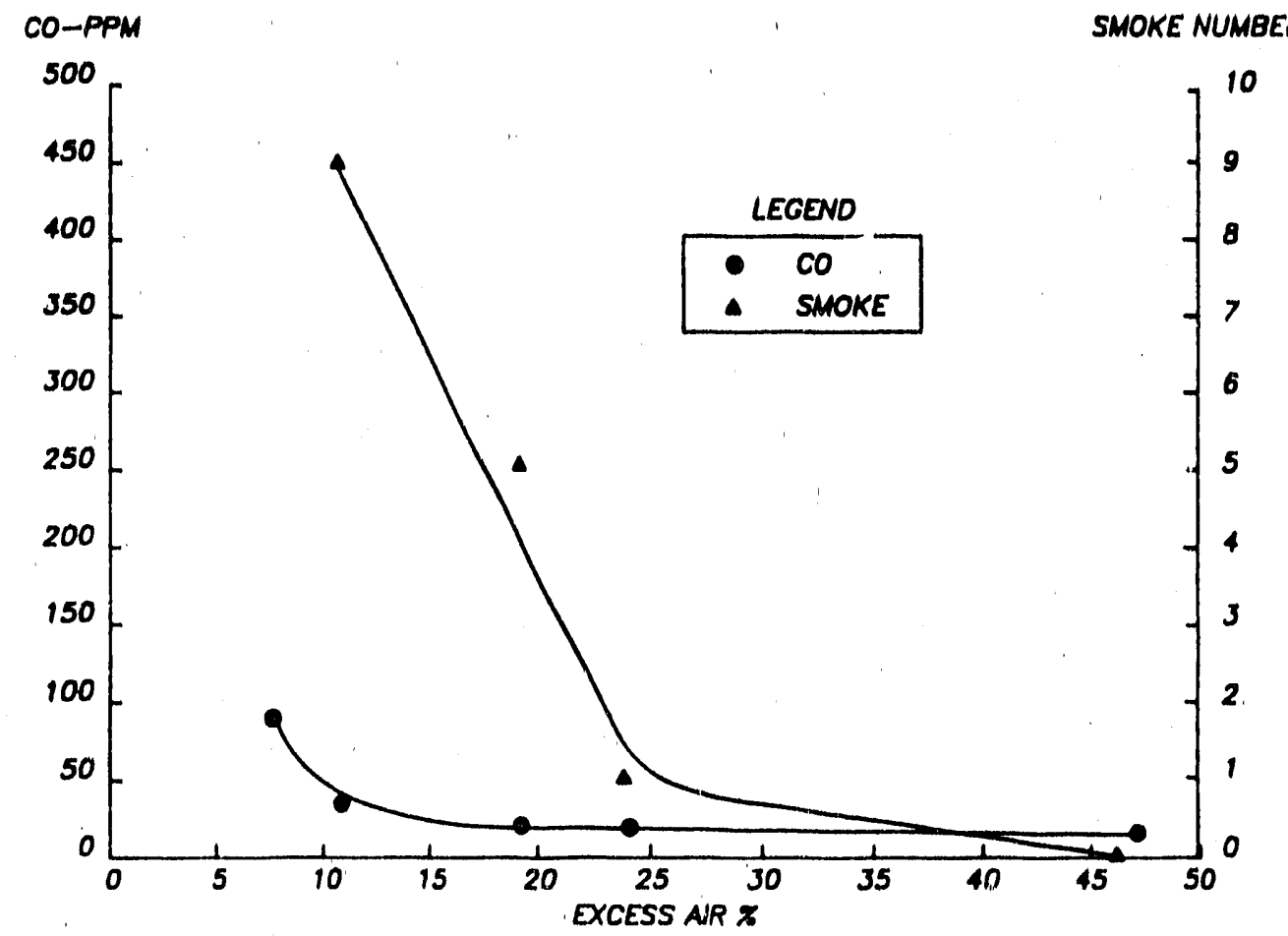

Figure 12. Measured smoke number and co emissions over a range of excess alr levels. Condensing warm alr furnace, $0.5 \mathrm{gph}$.

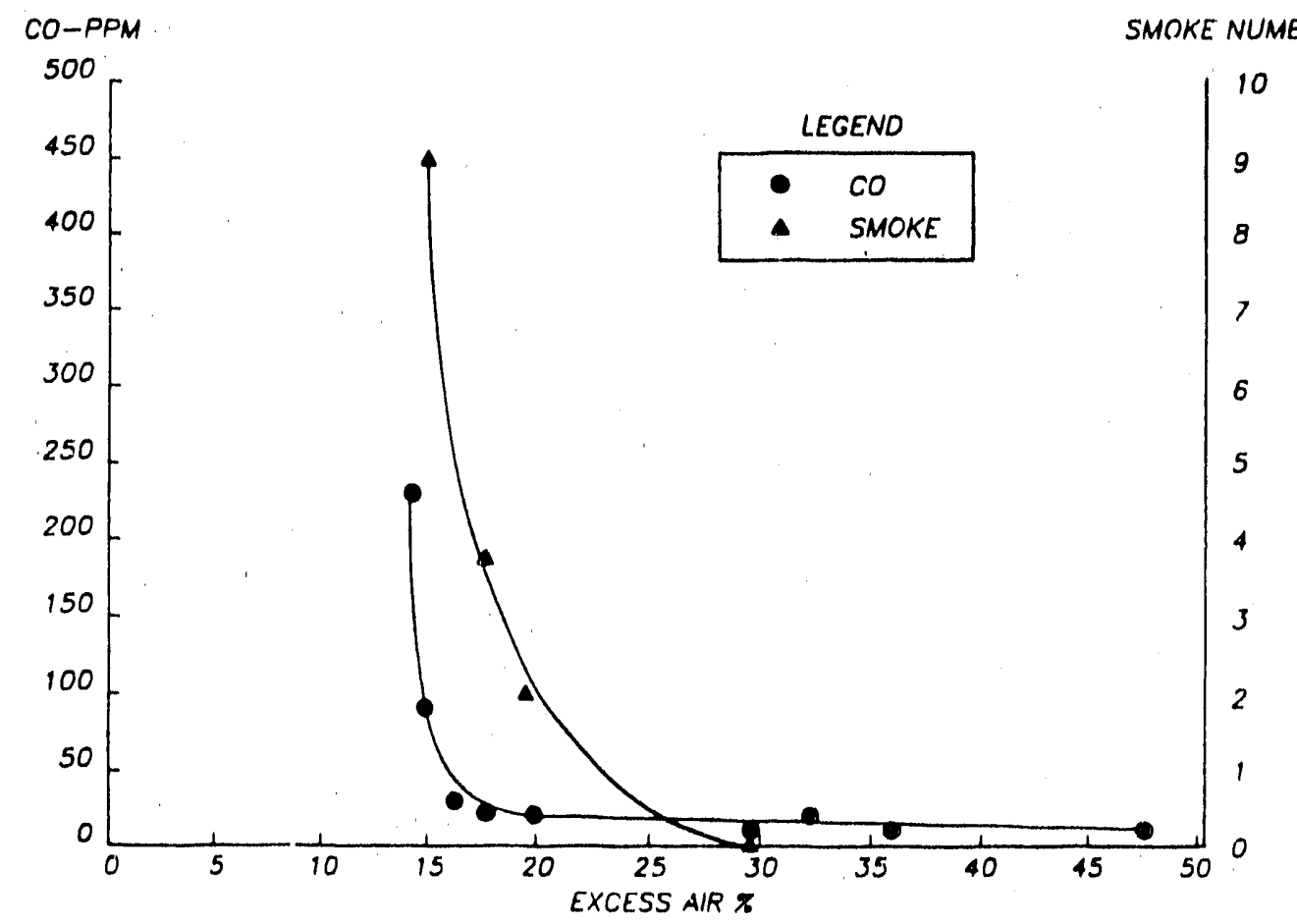

Figure 13. Measured smoke number and $C O$ enissions over a range of excess atr levels. Warm a ir furnace, $1.00 \mathrm{gph}$. 


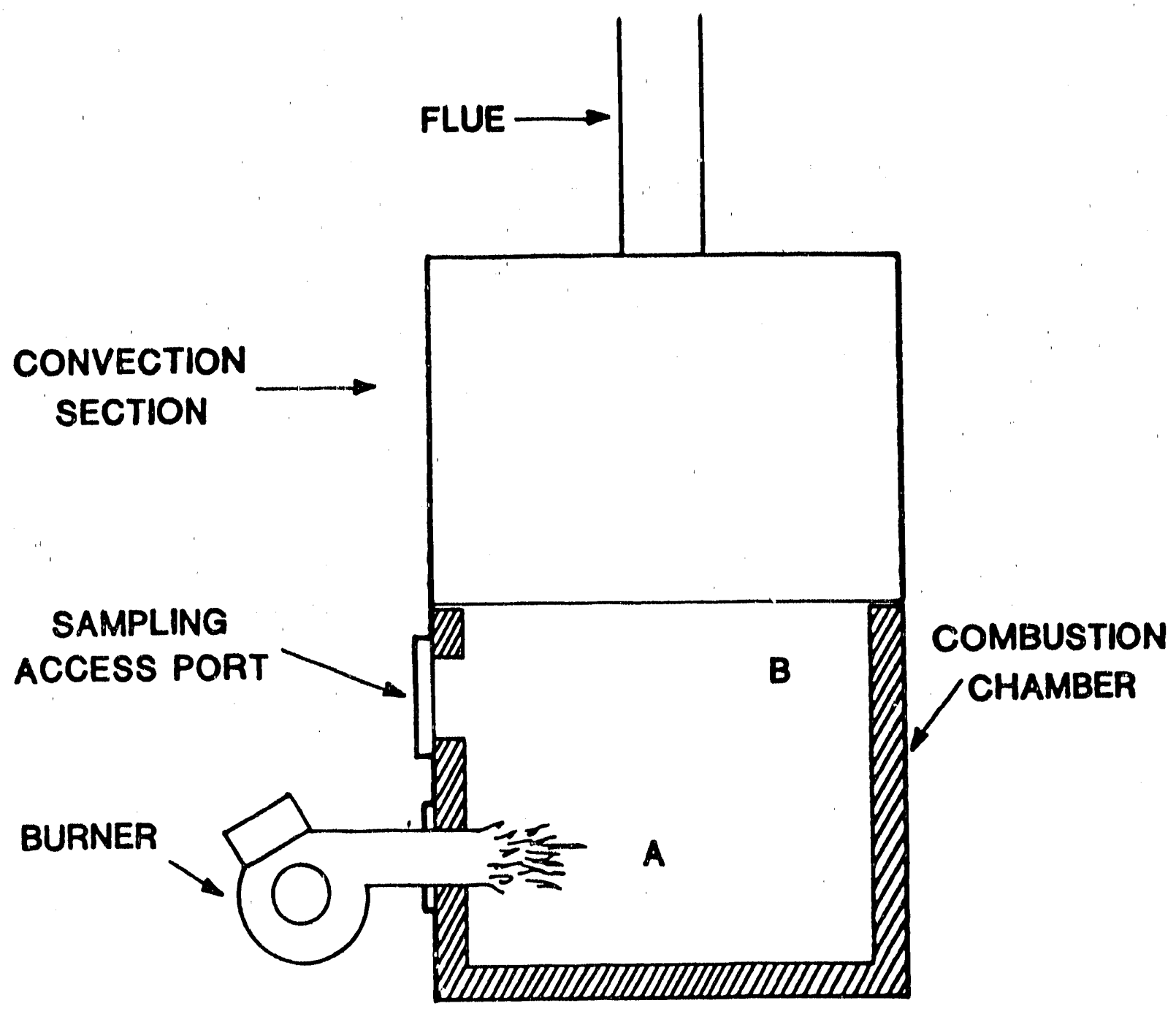

Figure 14. Location of Sampling Points in Combustion Chamber. 


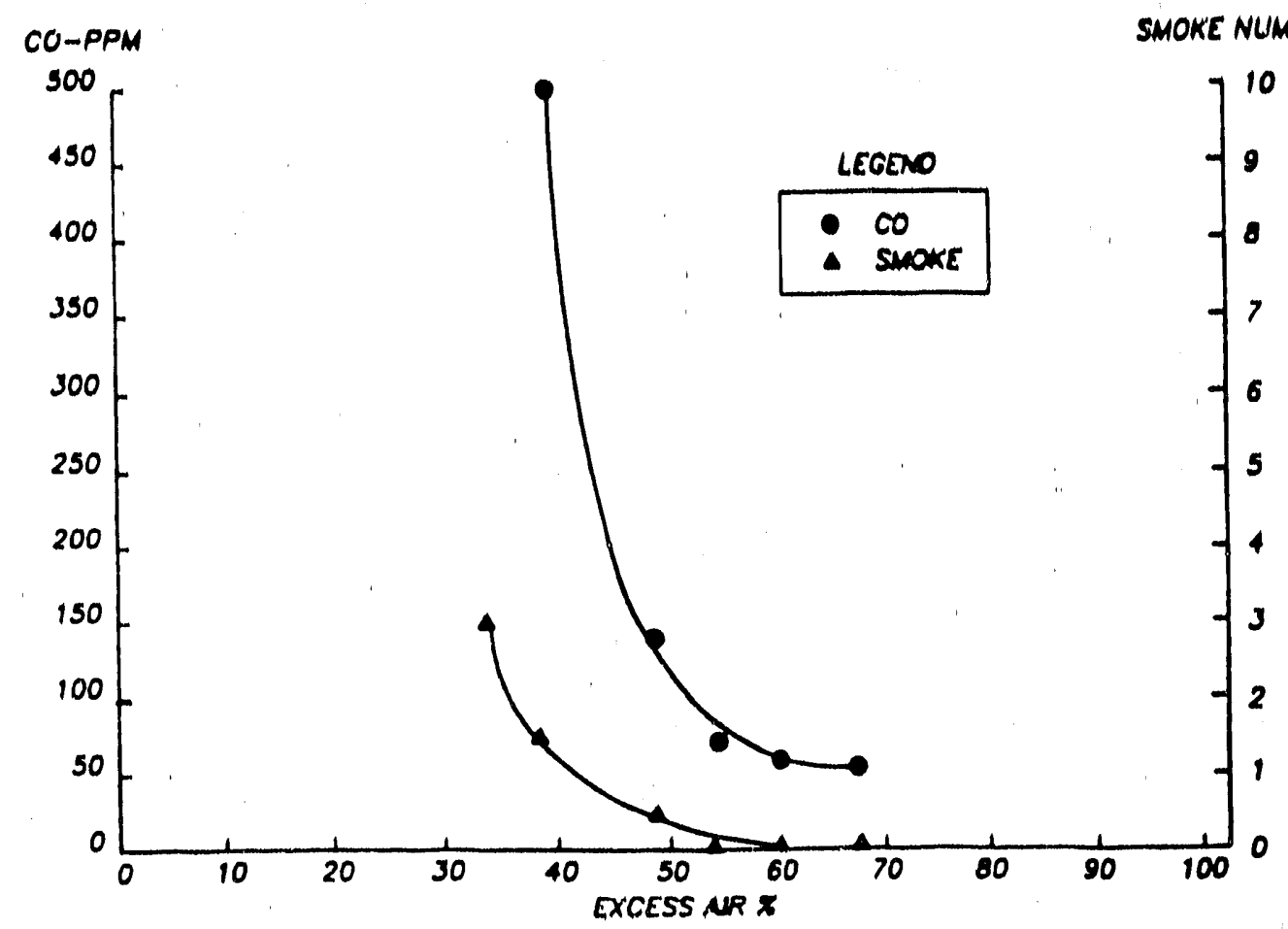

Figure 15. Measured smoke number and $\mathrm{CD}$ emissions over a range of excess air levels. Hot water boller, $0.65 \mathrm{gph}$. Sampling location for $\mathrm{CO}$ - A in Figure 14.

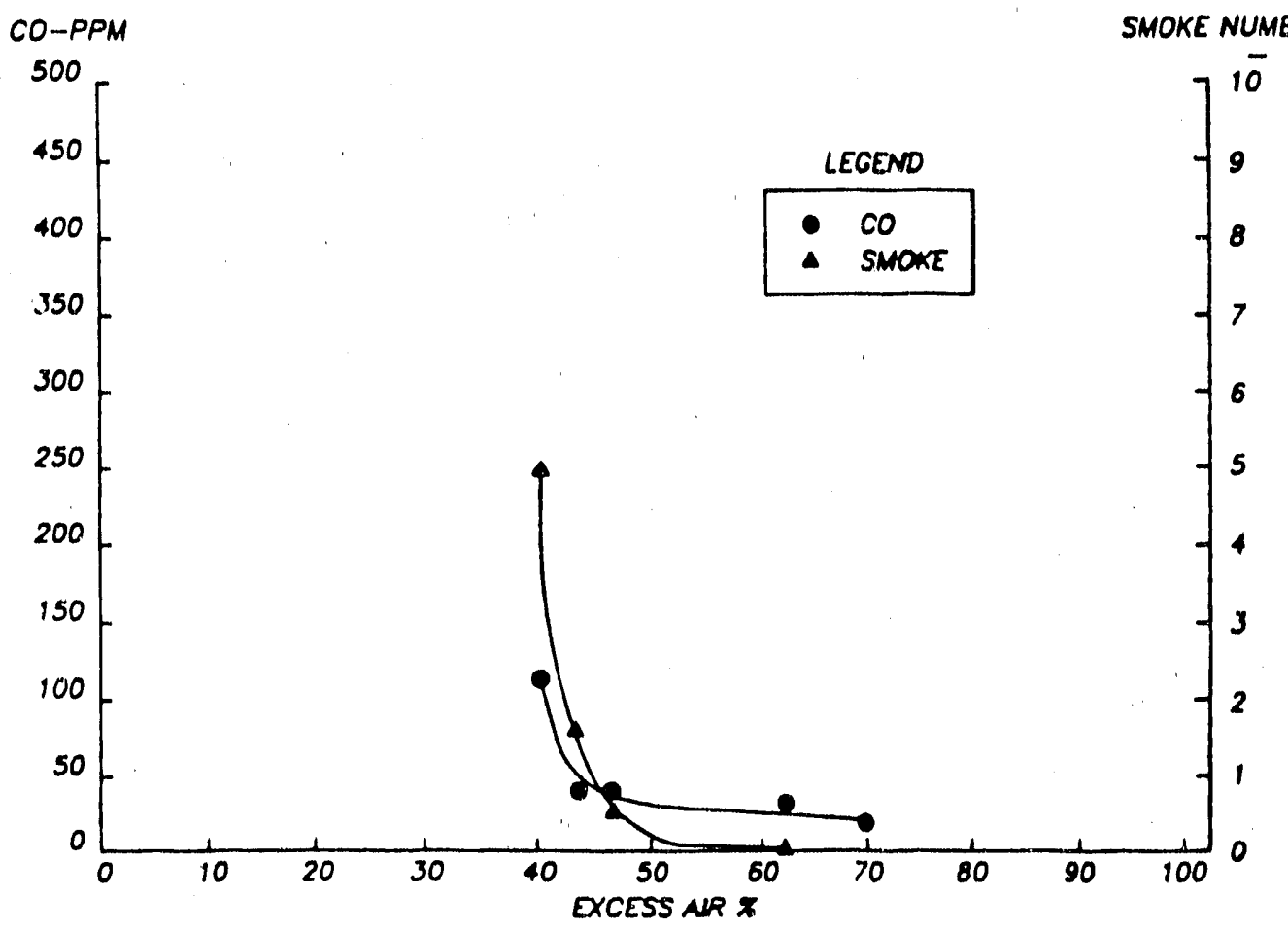

Figure 16. Measured smoke number and $C 0$ emlssions over a range of excess air levels. Hot water boiler, $0.65 \mathrm{gph}$. Sampling location for $\mathrm{CO}-\mathrm{B}$ in Figure 14. 
plotted versus the steady state smoke number for the three different sampling locations. This flgure very clearly indicates that CO measured closer to the flame zone would provide a better indlcator of flame quality than atack measurements.

Tests were also performed in the boller using a fouled nozzle. The nozzle used had a nominal rating of $0.65 \mathrm{gph}$ and had falrly heavy coke depos1ts on the front tip from prior use. Examination of the spray pattern showed the spray cone to be partially blocked. Measurements indlcated that the fouling resulted $1 \mathrm{n}$ a reduction $1 \mathrm{n}$ fuel flow of about $17 \%$ at the rated preasure. Figure 18 shows the smoke number/excess alr relationship for this nozzle. Comparison with Figures 10 and 11 indicates much greater smoke levelo with the fouled nozzle as expected. Meagurements indicated very low co concentration In the stack over the entire excess alr range examined. A stack Co measurement would not have indlcated that the nozzle condition had degraded. Measurement made in the combustion chamber indicated higher CO levels than in the stack, but these measurements also could not be used to algnal a poor quality flame condition.

\subsection{Effect of Parameters on Flue Gas Exit. Temperature}

In interpreting the results of these parametric tests on gas exit temperature it $1 \mathrm{~s}$ useful to compare the measurements with a simple heat exchanger mode1. A model of this type serves as a check on the reasonableness of experimental results and can be used to extrapolate experimental results to other cases. In the next few paragraphs the model asgumptions are presented.

F1gure 19 1llustrates a simple one-pass parallel-flow heat exchanger model which could be used for a boller or furnace. The "hot fluld" entering is assumed to be the combustion products at the adlabatic flame temperature. For this case the tota! heat transfer rate wlll be:

$$
Q=U A \cdot L M D T
$$

where

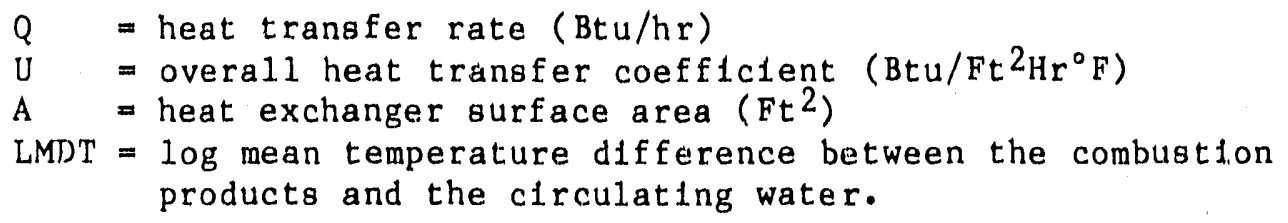

The product $U \cdot A$ in equation 1 can be determined using experimental data at one condition termed the "baseline." The model would then be useful for predicting changes from that baseline condition.

While such a simple model could be expected to approximately describe the effects of changing inlet conditions on heat transfer, 1 ts accuracy will be limited for several reasons. These include 1) the LMTD assumes heat transfer by conduction and convection while radiation also plays a role in ofl fired boilers and furnaces, and 2) the constant $U$ in equation 1 is expected to be constant when in fact 1t will be dependent on flow rate. 


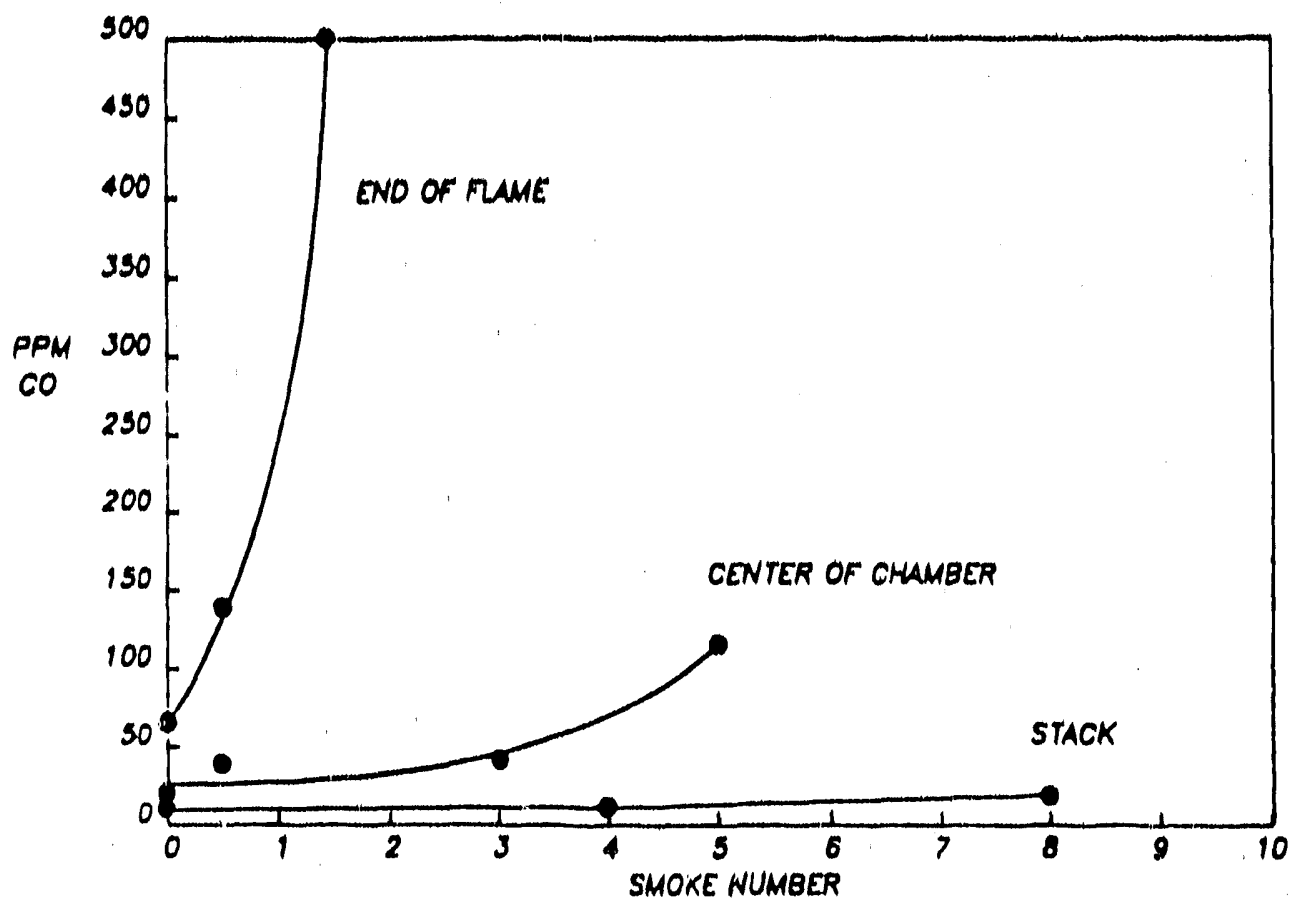

Figure 17. Relationship between $\mathrm{CO}$ and smoke number with three sampling locations for CO. Hot water bollur, $0.65 \mathrm{gph}$.

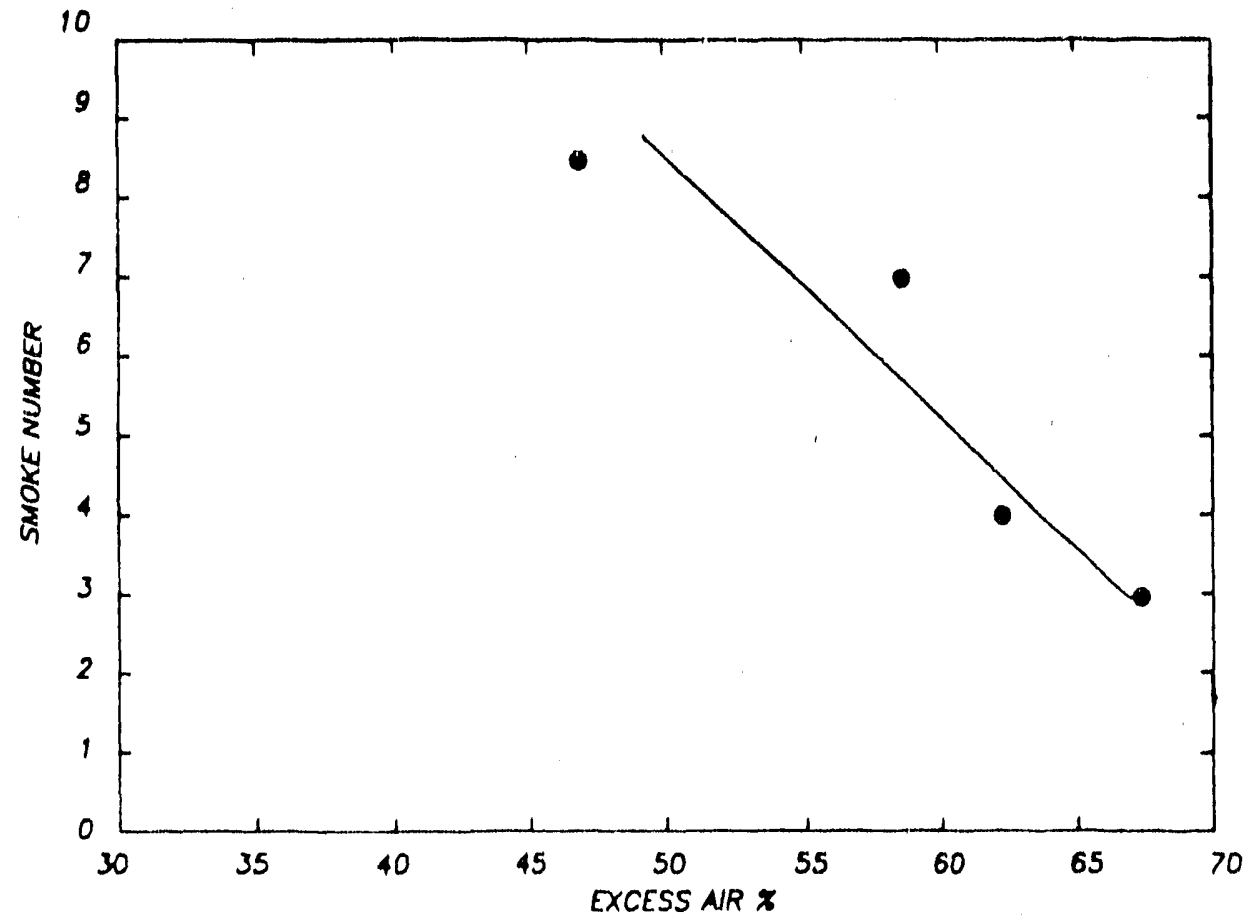

F1gure 18. Smoke number vs excess alr with a fouled nozzle. Hot water boller. Nominal nozzle rating - $0.65 \mathrm{gph}$. 


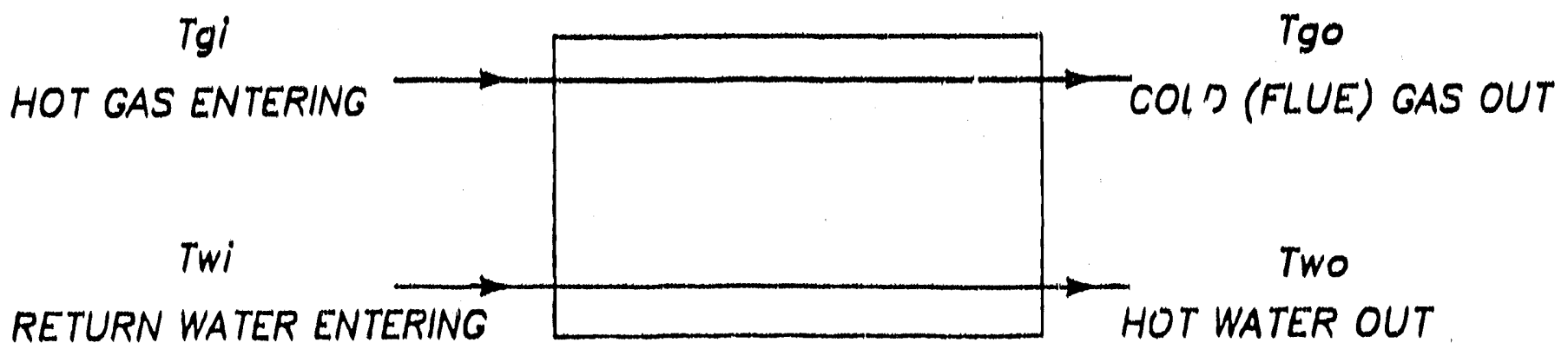

Figure 19. Illustration of a boller (or furnace) as a simple, parallel flow hot exchanger.

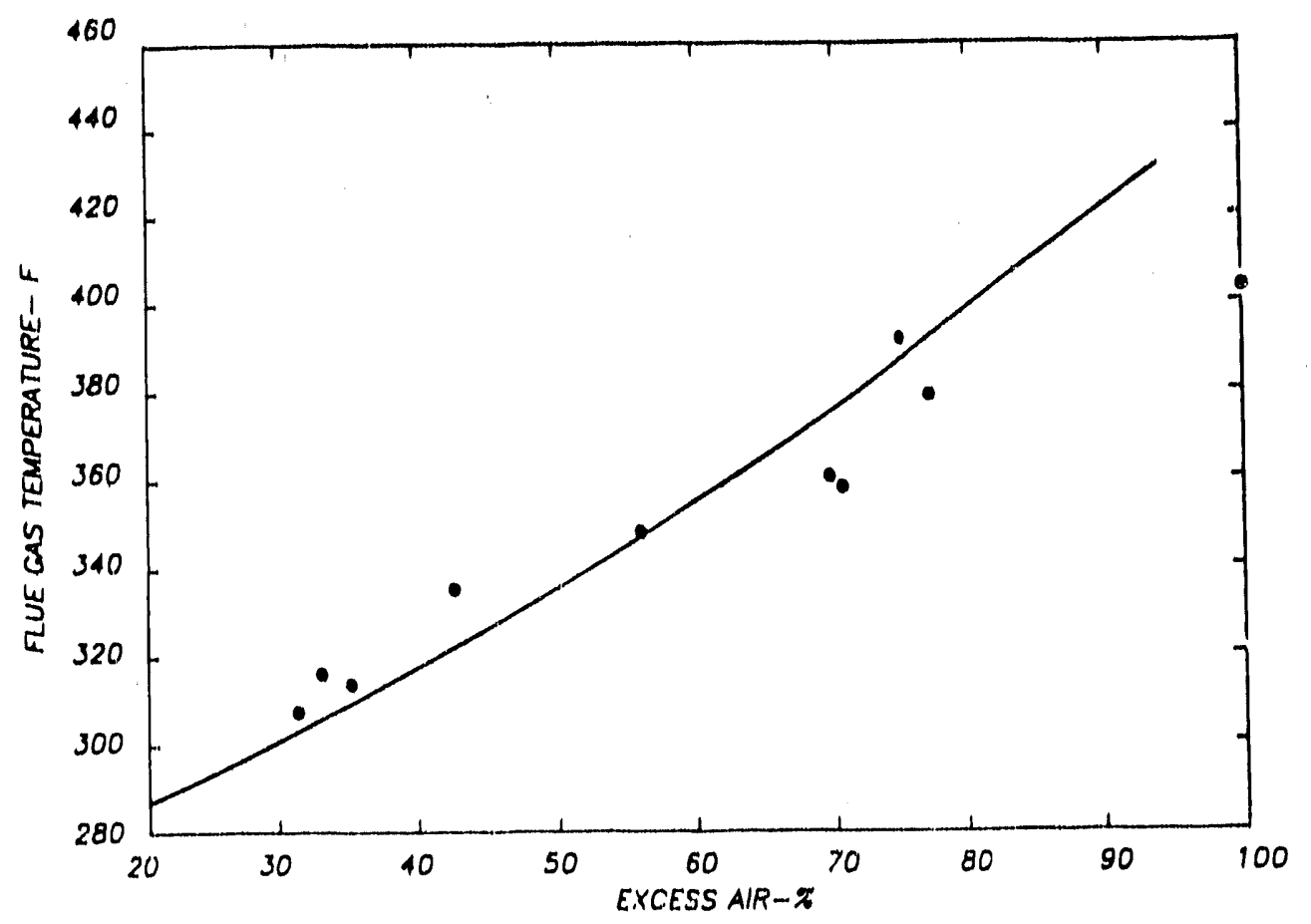

Figure 20. Effect of excess alr on flue gas temperature. Hot water boller, $0.65 \mathrm{gph}$. Data $(\cdot)$ and $t r$ end predicted by simple heat exchanger model $(-)$. 
For a change froin the baseline condtition the heat trangferred from the combuation productio to the boldar water can be expreased as

$$
Q=U_{B}-M_{8} C_{P B}\left(T_{80}-I_{g O b}\right)
$$

where

$$
\begin{aligned}
& Q_{B} \text { - Heat glven up by the gas in the baseline case (Btu/hr) } \\
& \mathrm{M}_{\mathrm{y}} \text { - Masa flow rate of combuation products (Lb/hr) } \\
& C_{p s} \text { - Maan spectilc heat of the combugtion products (Btu/Lb }{ }^{\circ} \mathrm{T} \text { ) } \\
& \text { Tob - Gas outilet temperature in the basaline caso ( } \left.{ }^{\circ} \mathrm{F}\right) \\
& \left.\mathrm{T}_{\text {yo }}^{\mathrm{O}} \text { "Gag outlet temperature ( }{ }^{\circ} \mathrm{F}\right) \\
& \text { Also, the heat gatned by the bolier water can be expressed a } \\
& Q=M_{W} C_{W W}\left(I_{W O}-I_{W L}\right)
\end{aligned}
$$

where

$$
\begin{aligned}
& \mathrm{M}_{W}=\text { Masa flow of water }(1 \mathrm{~b} / \mathrm{hr}) \\
& \mathrm{C}_{\mathrm{pw}}=\text { Spectflc heat of water }\left(\mathrm{Btu} / 1 \mathrm{~b}^{\circ} \mathrm{F}\right) \\
& \mathrm{T}_{W 0} \text { - Water outlet temperature }\left({ }^{\circ} \mathrm{F}\right) \\
& \mathrm{T}_{W 1}=\text { Water inlet temperature }\left({ }^{\circ} \mathrm{F}\right)
\end{aligned}
$$

By volving equations 1,2 , and 3 simultaneously, the effect of changlng conditions on flue gas exlt temperature can be predicted. The equations are non-linear and an Lterative procedure must be used. At the baseline condition used for the boller U.A was found to be $84.22 \mathrm{Btu} /{ }^{\circ} \mathrm{F} \mathrm{hr}$.

Flgure 20 showg the varlation of flue gas extt temperature with excess air for the boller fired at $0.65 \mathrm{gph}$ (constant water temp.). Also shown $1 \mathrm{~s}$ the trend predicted by the simple heat exchanger model. The model predicta a breater change fin flue gas temperature with excess alr than the data.

For changes in the boller water temperature the model predicts about an $11^{\circ} \mathrm{F}$ rise in atack temperature for a $10^{\circ}$ rise in boller water temperature (1U. $7^{\circ}$ at $20 \%$ excess atr; $11.6^{\circ}$ at $100 \%$ excess alr). This la roughily equivalent to a constant differential between stack tenperature and boller water temperature. Flyure 21 showg data on the difference between stack temperature and boller water temperature over a range of boller water temperatures at congtant excess alr. As this figure shows, the temperatidre differential decreases with increasing boller water temperature. Over the range from 130 to $220^{\circ} \mathrm{F}$ boller water temperature, which 18 the maxtmum expected range over a typlcal heating season, the temperature differential. changes by about $16^{\circ} \mathrm{F}$. The model assumptions in this case as well as the expertmental data are based on constant water filow rate, as would occur for example in the winter, when the house la calling for heat.

These results on the vartation of atack temperature whth boller water teinperature have suveral implicatione for control strategles. Certalniy, one 


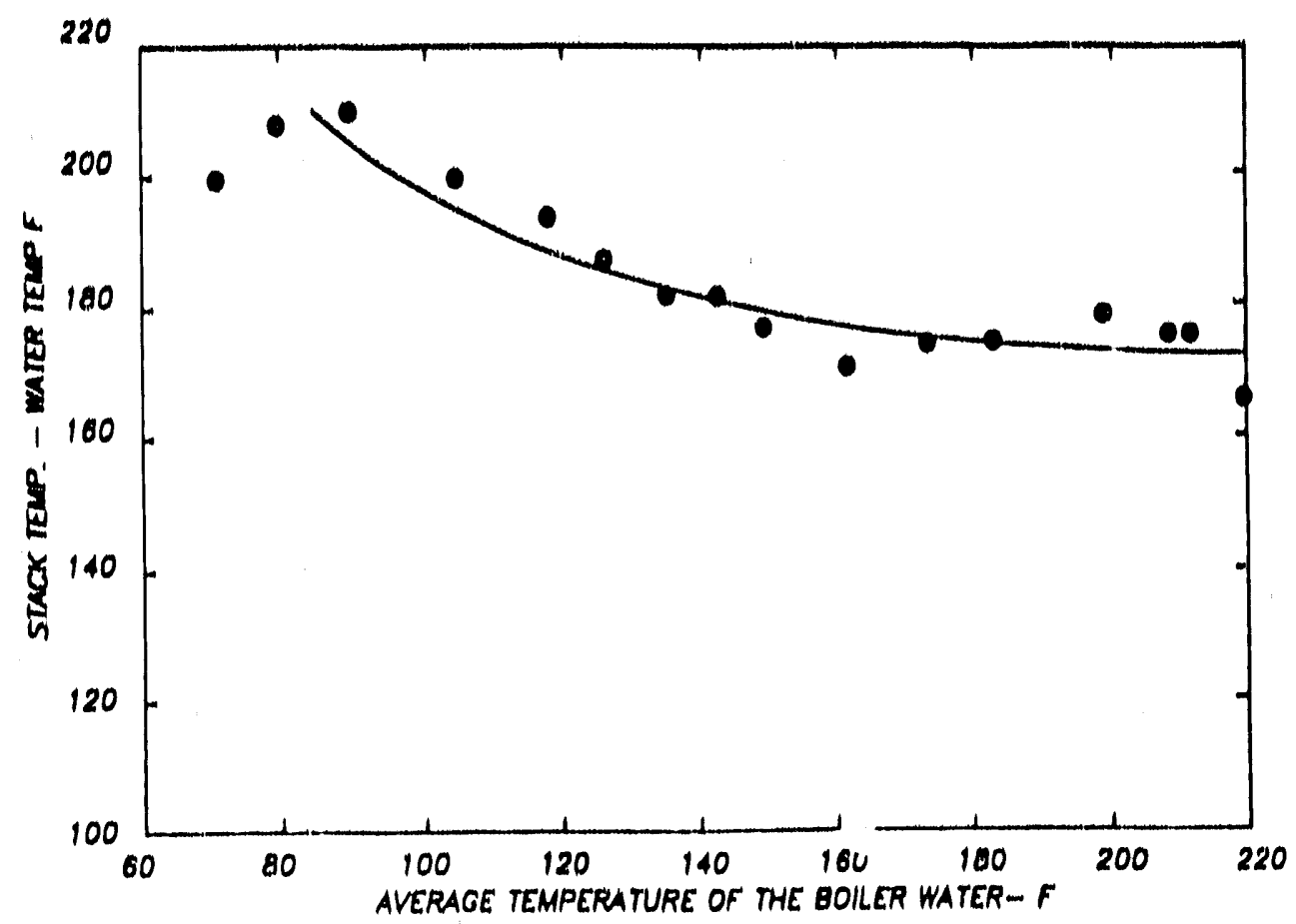

F1gure 21. Temperature difference between the stack and the boller water over a range of water temperatures, $0.65 \mathrm{gph}$.

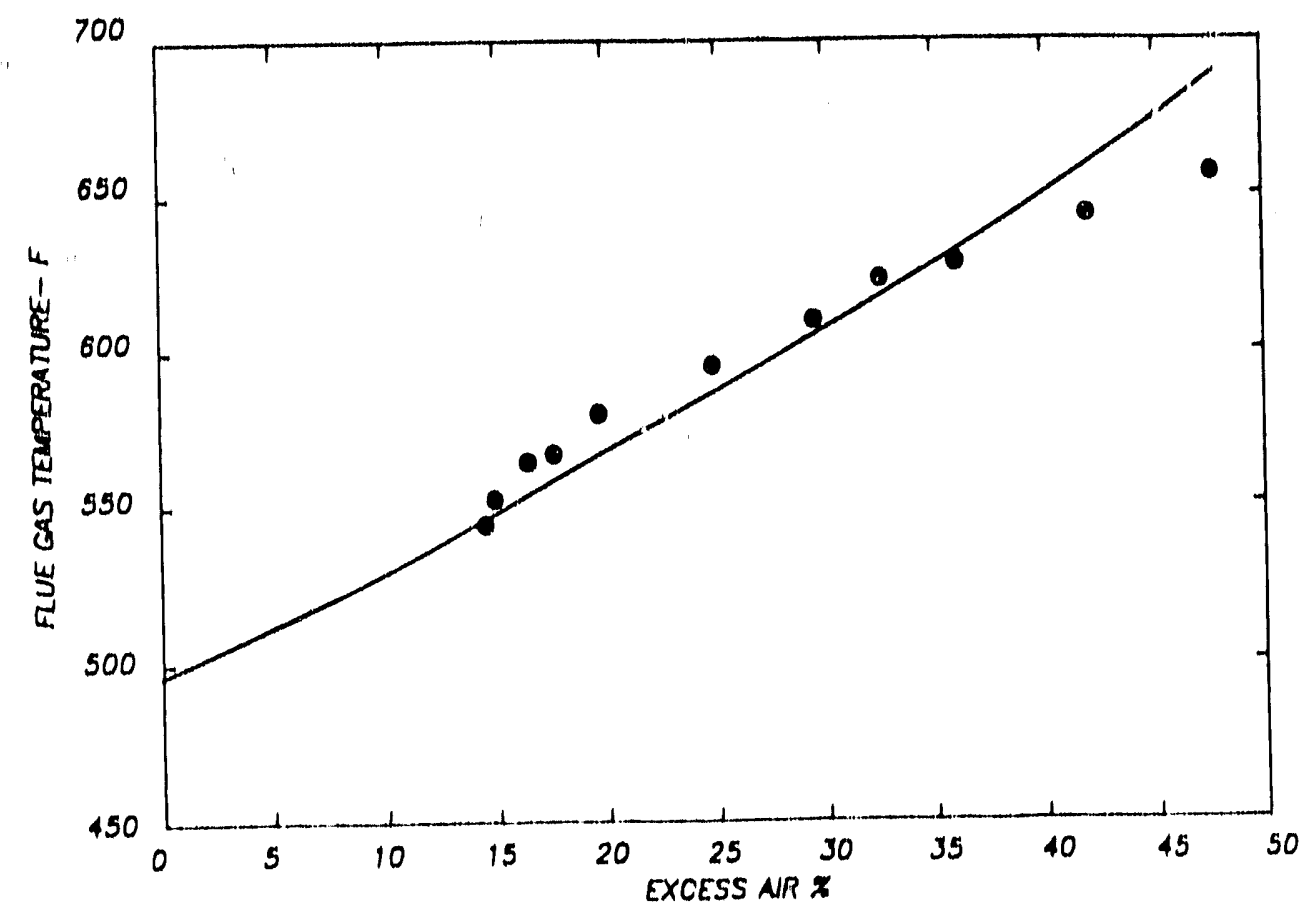

F1gure 22. Effect of excess air on flue gas temperature. Warma ir furnace, $1.0 \mathrm{gph}$. Data $(\cdot)$ and trend predicted by stmple heat exchanger model, ( $(-)$. 
vary almple control approach involvas montioring atack temperature alone, adihough this will vary olgniflcantily with the water temperature. For a fixed setilny on the controls, however, the burnet typlcaldy ghute off at a fidxed water temperature. Monitorlng of the maximum temperature readiaed durling normal hating sadson cycilng 1 g one method of eldminating the water temperam ture alfact. An altarnative, but a more complicated approach, would involve maduring the litue sas to water diflerential temperature. This would permit montioring of effictency changeg eteantialiy continuousdy during cyclic operaton. The vartation in this temperature differance over a norinal cycle could be compared with the ritae in stack temperature with degradation. At typlcal axcase alr lavelo and atgck temperaturas (non-condenaing) a $1 \%$ reduction in afficlency corresponda to a $36^{\circ} \mathrm{F}$ rlse in stack temperature. Considering the typlcal vartation in this differential a $1 \%$ change 1 about the mintmum which might be rollably indicated.

Studles were also done on the effects of changes in ambient alr temperature on atack temperature. The almple heat exchanger model predicta an Incraase in atack gas temperature of $4.1^{\circ} \mathrm{F}$ for a reduction in amblent temperature from 70 to $30^{\circ} \mathrm{F}$. Laboratory teats were conducted with amblents ranging Erom $72.5^{\circ} \mathrm{F}$ to $43.7^{\circ} \mathrm{F}$. Ovur this range stack temperature did incraase about 2 to $5^{\circ} \mathrm{l}$, although this could be congldered withln the normal varlation range. The relevant conclusion is that variations ln amblent alr temperature will not atinificantly affect a control strategy which uses stack temperature as an tipute.

A stimlar gerteg of teats were alao performed using the warm atr furnace. Agatn, a almple heat exchanger model simflar to that deacribed for the boller was used to compare with the trendr observed experimentally. ligure 22 shows the effect of excess afr on flue gail temperature and the trend predicted by the stimple inodel. As in the case of the boller, the model predicts a somewhat grater change with excess alr than the data Indleate.

In Flutre 23 the effect of changlng furnace alr flow on the measured atack temperature 18 shown along with the trend predicted by the model. While the flxed value of U.A used in this case predicts atack temperatures $10-15^{\circ} \mathrm{F}$ Lower than those measured, the trend 18 certalnly simllar. The range of alr flow rates studted produced an atr temperature rlse from 70 to $90^{\circ} \mathrm{F}$.

The simple model was used to predict the effect of changling amblent temperature on flue gas temperature. As In the case of the boller, the effect is falrly small. A change in ambient from 70 to $30^{\circ} \mathrm{F}$ produced only a $10^{\circ} \mathrm{F}$ change in stack temperature.

In normal heating season operation, a furnace would typlcally have a nearly constant return air temperature and warm alr flow rate. Under this condition, the stack temperature will depend only on firting time and excess alr. The time for lihe stack gas to approach 1 ts ateady state temperature varies. In the system tested the time was about three minutes, which could be consldered typlcal. Based upon the results avallable to date, simple measurement of the peak stack temperature may be the most rellable indicator of performance degradation. During the warm up rransient the difference between the live gas temperature and the warm atr exit temperature is not constant, 


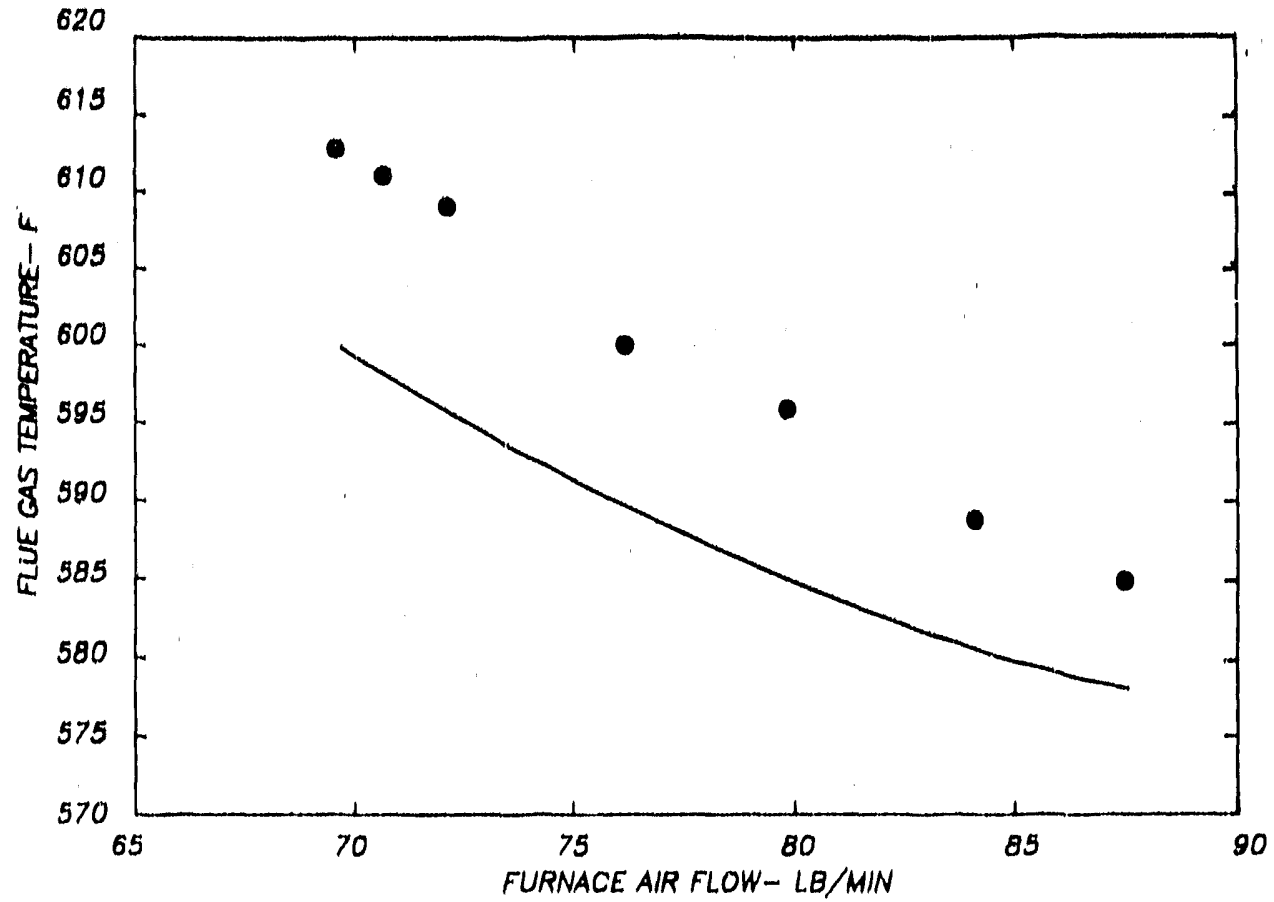

Figure 23. Effect of chang Ing furnace alr flow on stack temperature. Data $(\cdot)$ and simple heat exchanger model, trend (-). 
eliminating this as an approach to continuously monitoring performance during the burner on-cycle.

\subsection{Longer Term Degraded Performance Tests}

Both the previously described boller and the warm air furnace were operated with high smoke numbers for an extended period of time. The purpose of this test was to measure changes in flue gas temperature, flue pipe surface temperature, gas side pressure drop, air flow rate and $C O$ emissions as the systems fouled.

The boiler test stand was arranged with the burner cycling under control of the aquas"it, the circulator ran constantly, and the thermal load was adjusted (by adjusting heat dump fan speed) to produce a cycling pattern of 5 min. on- 10 min. off. The burner was adjusted to $11 \%$ excess air $\left(2.2 \% \mathrm{O}_{2}\right.$ or $\left.14 \% \mathrm{CO}_{2}\right)$.

Figure 24 shows the variation in measured smoke numbers during a typical cycle. These snoke numbers were obtained with a constant rate sampling system and represent averages over $15 \mathrm{sec}$. It is interesting to note the low startup smoke level with this burner.' This is likely a combined result of the high static pressure fan in the burner and the fairly rapid cycling pattern. Under rapid cycling the flue and refractory remain warm during the of $\mathrm{f}$ cycle.

The boiler test duration was 36 days, 4 hours. During this time the burner operated for a total of 289 hours and cycled 3,472 times. With a 1.0 gallons/hours nozzle, 289 gallons of oil were consumed during this test.

Figure 25 shows the measured trend in flue gas temperature during the test. This temperature was measured at the center of the flue pipe, and represents the maximum observed during the firing cycle. As this figure shows, the rate of increase in flue temperature was steady until about day number 26, at which time it increased notably. At this point a small increase in smoke number was also observed indicating a deteriorated nozzle condition. The rise in flue gas temperature observed during this test $\left(131^{\circ} \mathrm{F}\right)$ corresponds to a decrease in thermal efficiency of $2.9 \%$.

In Figure 26 the trend in flue pipe surface temperature during the test period is shown. Comparison with Figure 25 shows that the flue pipe surface temperature followed the gas temperature trend. The overall rise in the pipe temperature, however, was lower than for the gas $\left(91^{\circ} \mathrm{F}\right.$ vs $\left.131^{\circ} \mathrm{F}\right)$. This trend is not unexpected. As soot deposits collect on the inner wall of the flue pipe, the temperature difference between the gas and the pipe will rise.

Following the termination of the boiler test the unit was disassembled for a detailed inspection and cleaning. The thickness of the soot coating varied significantly with location, but averaged about $1-1 / 2 \mathrm{~mm}$. The thickest deposits were located around the extended surface in the convective section and blocked some of the flow area. The total mass of soot removed from the boiler surfaces was 250 grams.

In the furnace tests the burner operated $10 \mathrm{~min}$. on $/ 15 \mathrm{~min}$. off with a steady state excess air level of $23 \%\left(4.1 \% \mathrm{O}_{2}\right.$ or $\left.12.5 \% \mathrm{CO}_{2}\right)$. The furnace was 


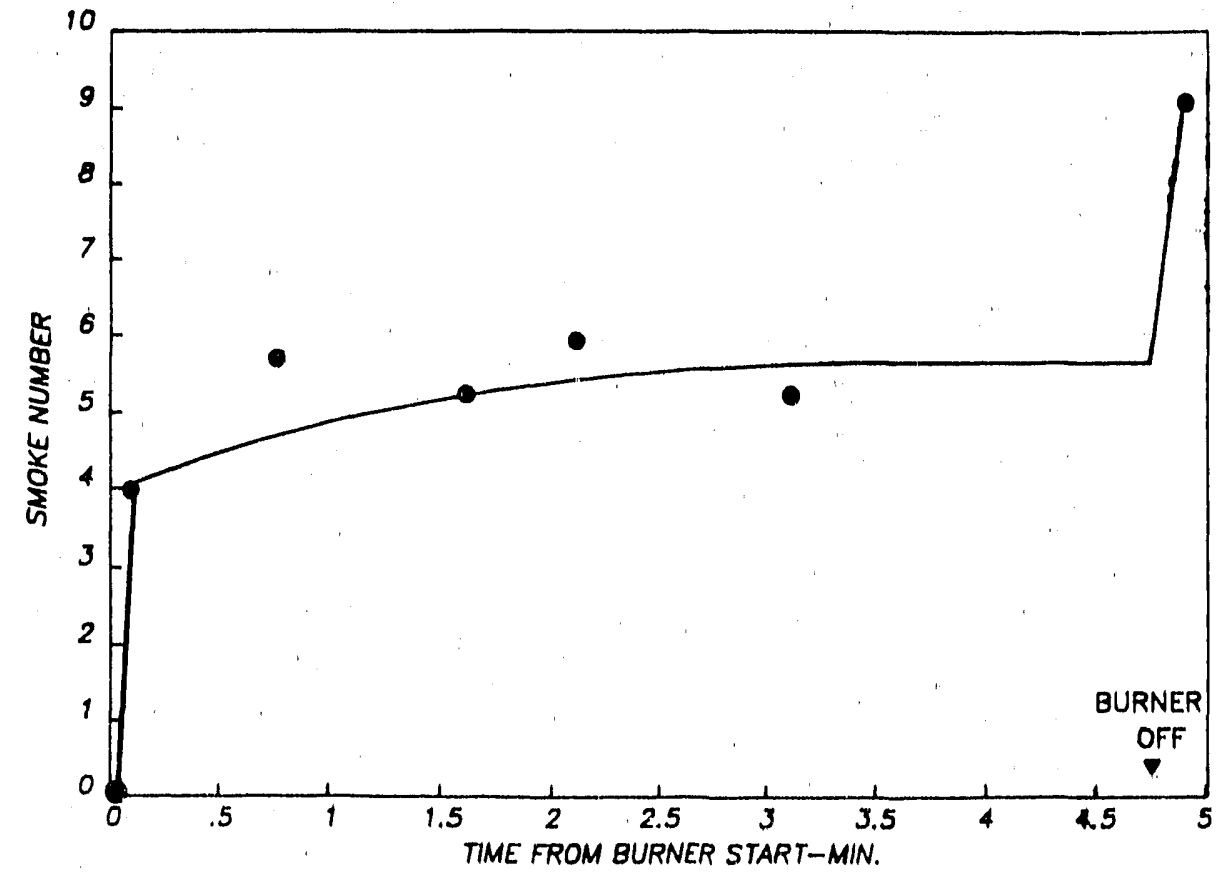

Figure 24. Measured smoke numbers over a typical firing cycle Boiler longer term performance test.

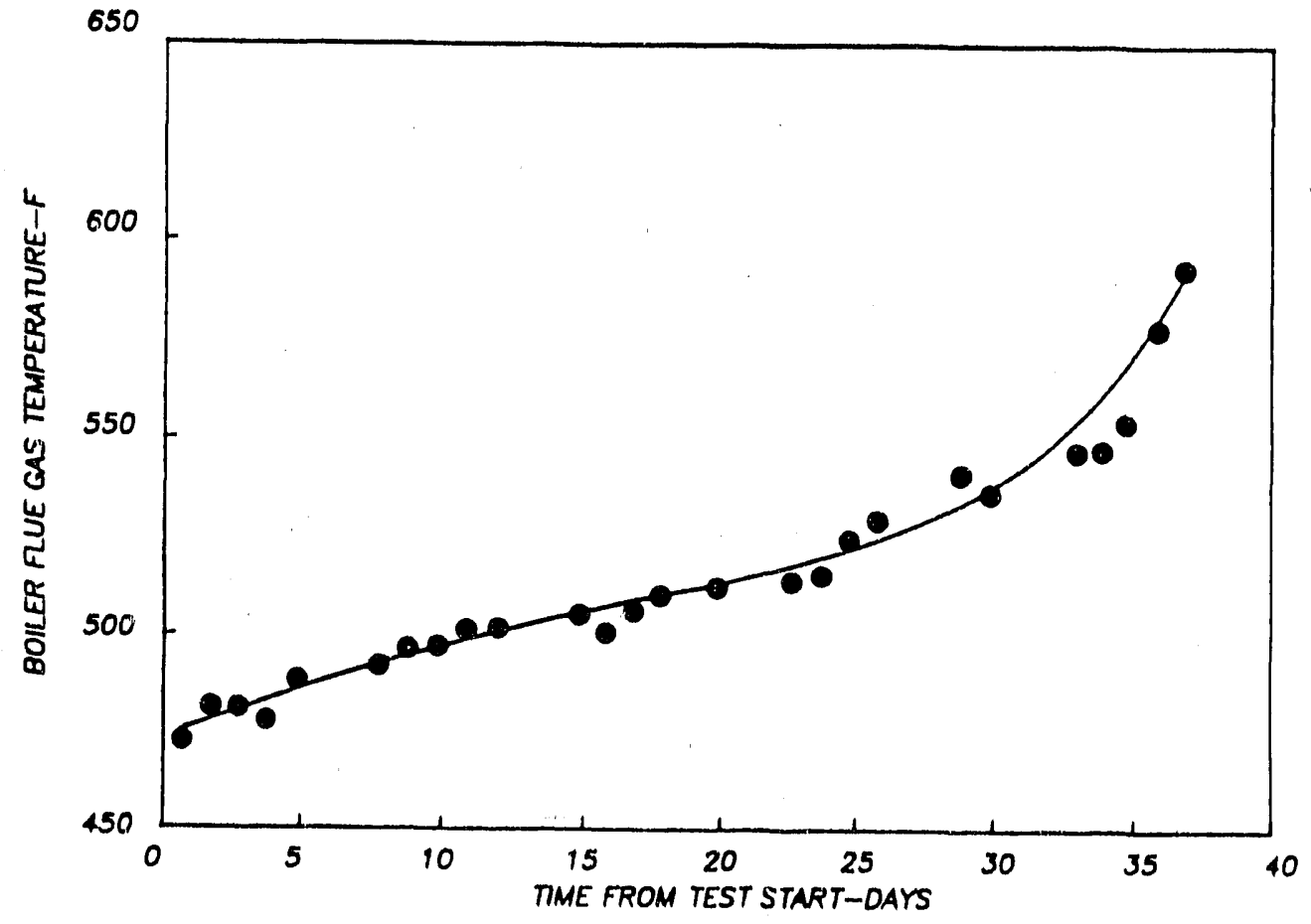

Figure 25. Flue gas exit temperature. Cycle maximum Boller longer term performance test. 


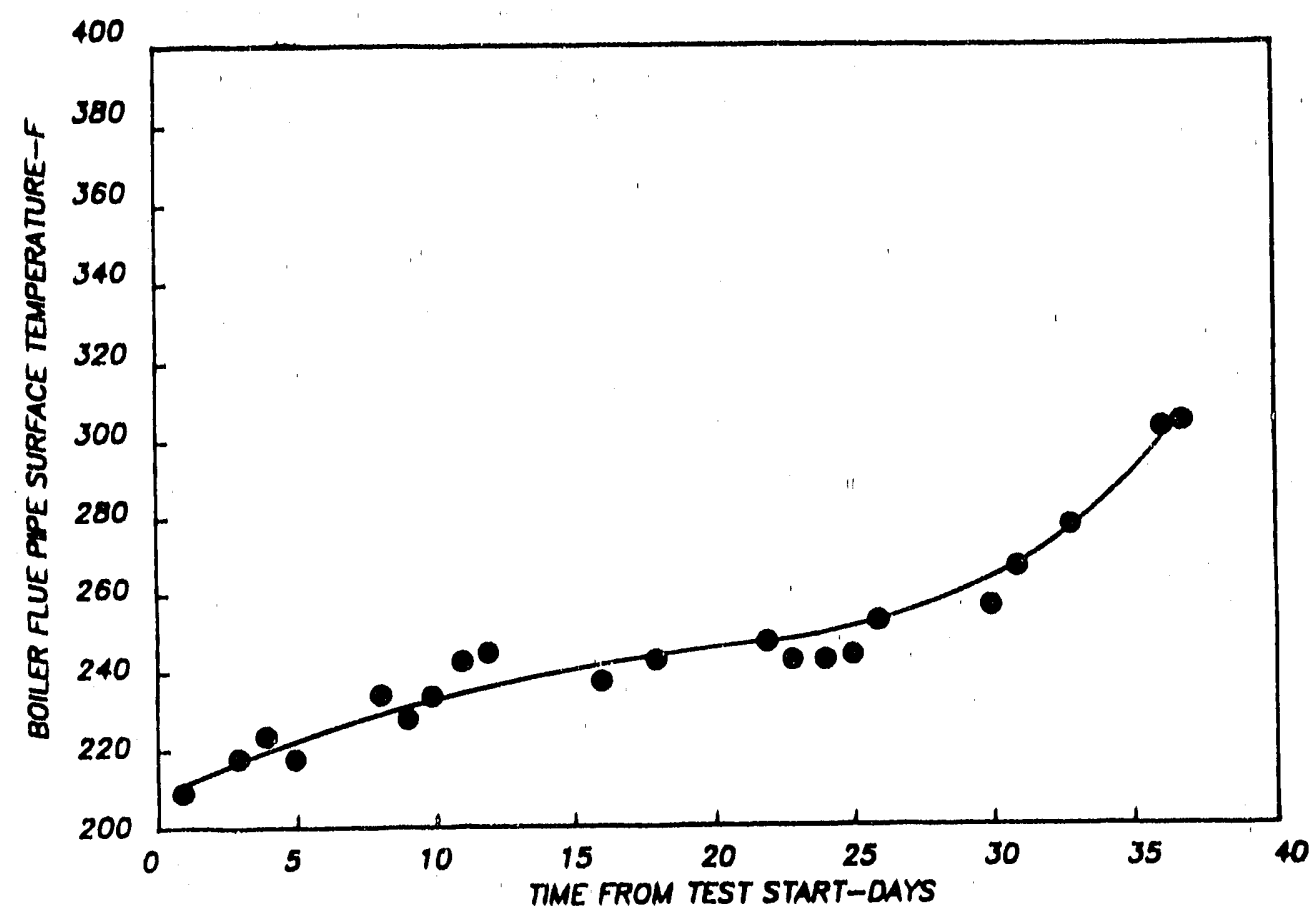

Figure 26. Flue pipe surface temperature - Cycle maximum-boiler longer term performance test.

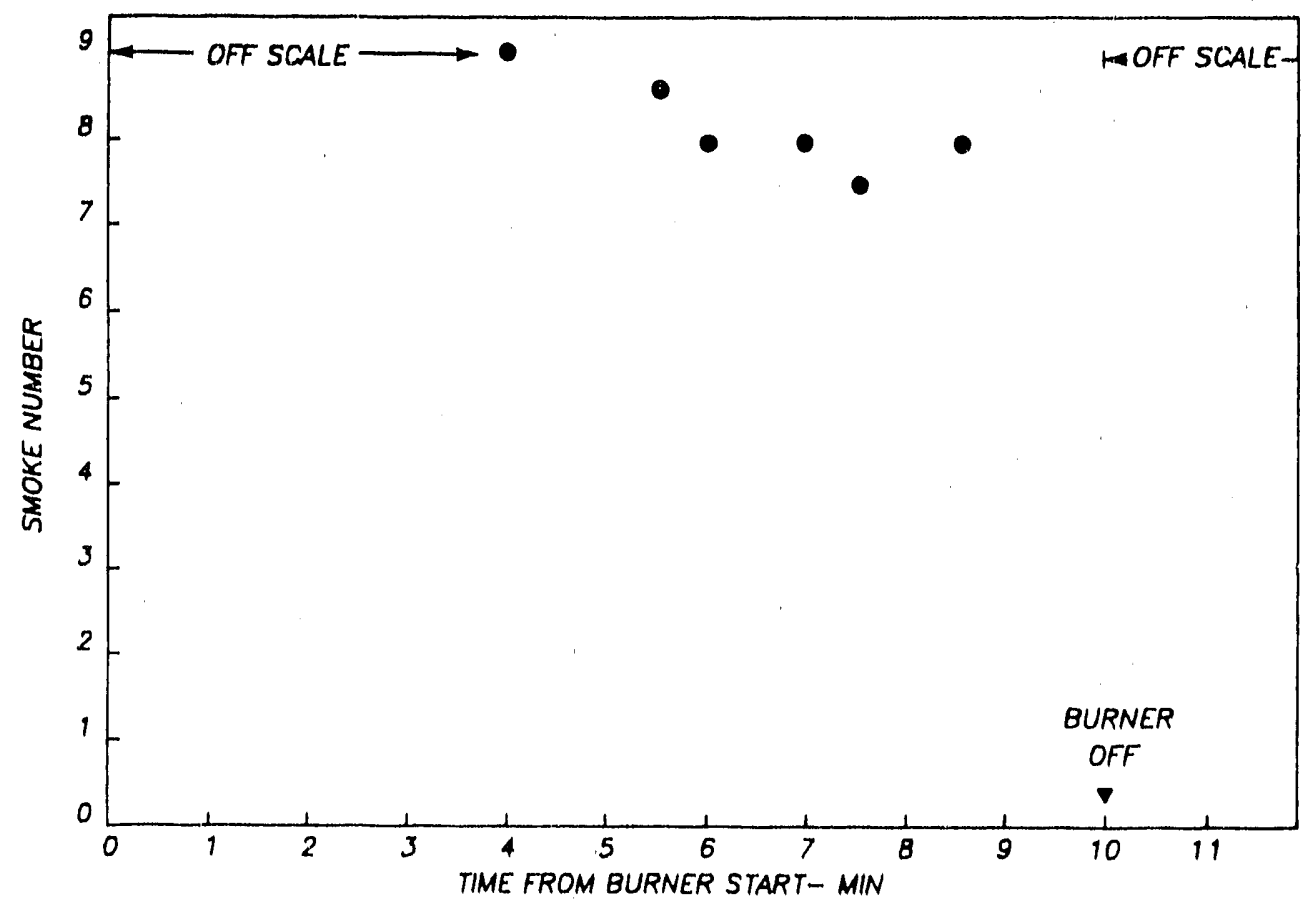

Figure 27. Measured smoke numbers over a typical firing cycle Furnace longer term performance test. 
configured to have significantly higher smoke numbers than the boller. Figure 27 shows the variation in measured smoke numbers over a typical firing cycle. At equal smoke levels the fouling rate of a furnace would be expected to be lower than for a boiler. This, presumably, is due to higher heat exchanger surface temperatures with the furnace and a more complex heat exchanger geometry in the boller. In the furnace the heat transfer surface, is essentlally a smooth steel drum with alr on one side and gas on the other. In the boiler there are many fins on the gas side of the cast iron sections.

The duration of the furnace test was 50 days. During this time the burner ran for 396 cumulative hours and cycled on/off about 2400 times. At a firing rate of $1 \mathrm{gph}, 39.6$ gallons of oil were consumed during this test.

Over the period of the test excess alr decreased from $24 \%$ to $14 \%$ and flue gas CO content increased from roughly $35 \mathrm{ppm}$ to $55-100 \mathrm{ppm}$. Smoke numbers, which were greater than 7 Bacharach over the entire firing cycle, wert found to increase slightly over the test period.

During the test the steady state flue gas temperature rose from 552 to $626^{\circ} \mathrm{F}$, a $74^{\circ} \mathrm{F}$ rise. At constant excess air this rise in flue gas temperature corresponds to a reduction in efflciency of $1.8 \%$. With the reduced excess air this efficiency decrease is $1.2 \%$.

It is interesting to note that the rise in flue gas temperature with the furnace was about $1 / 2$ of the rise observed in the boller test $\left(131^{\circ} \mathrm{F}\right.$ vs. $\left.74^{\circ} \mathrm{F}\right)$. This occurred even though the steady state smoke numbers were significantly higher in the furnace test and the burner ran longer in the furrace test ( 396 hours vs. 289 hours).

After termination of the test the furnace was disassembled for inspection of the heat exchanger surfaces. As with the boller, the soot deposits varied significantly with location. Thickness ranged from 1 to as much as $6 \mathrm{~mm}$. The total mass of soot removed from the heat exchanger surfaces was $175 \mathrm{~g}$.

Generally, the furnace deposits and boiler deposits were comparable in magnitude. It seems likely that the greater rise in flue gas exit temperature with the boller was due to the heat exchanger configuration. In the furnace soot deposits simply coat the surface of the steel heat exchanger drum. In the boller, however, soot deposit bridging occurs around the extended surface. This can significantly modify gas flow, leading to channeling.

\subsection{Tests on Oxygen Sensors}

\section{Stack Probe Z1.rconium Sensor}

Tests using the commerclal zirconium oxide probe, (Philips) were done both in steady state, with varied excess air and over cyclic operation. For comparison purposes the flue gas oxygen content was also measured using a paramagnet1c analyzer (Beckman-Mode1 755). The paramagnetic analyzer, which Is fed clean, dried flue gas, indicates oxygen concentration on a "dry" basis. The zirconium oxide probe, however, indicates oxygen partial pressure In the total flue gas, Including water vapor. To put both on an equivalent 
basis these oxygen contents can be converted to \% excess air ueing the following equations for a typical number 2 ofl:

$\mathrm{O}_{2}$ on a dry basis:

$$
\% E A=\frac{4620 \cdot O D}{(1037.5-0 D \cdot 49.375)}
$$

$\mathrm{O}_{2}$ on a wet basis:

$$
\% E A=\frac{O W \cdot 100(52.55+W \cdot 78.85)}{(1037.5-49.375 \cdot O W-W \cdot 78.85)}
$$

where:

$$
\begin{aligned}
\% \mathrm{EA}= & \% \text { Excess Ai } \mathrm{r} . \\
\mathrm{OD}= & \text { Oxygen concentration in flue gas with water vapor removed }-\% \\
& \text { molar (volume) basis. } \\
\mathrm{OW}= & \text { Oxygen concentration in flue gas (including water vapor) }-\% \text { molar } \\
& \text { (volume) basis. } \\
\mathrm{W}= & \text { Ambient air moisture content, } 1 \mathrm{bs} / 1 \mathrm{~b} \text { dry air. }
\end{aligned}
$$

Figure 28 shows a comparison of the excess afr determined from the zircontum oxide and the paramagnetic analyzers. Agreement is reasonably good over the range examined. Flgure 29 shows the smoke number/excess air (based on the paramagnetic analyzer) curve for the system tested. The in-stack zirconium probe performed well even at smoke numbers well in excess of normal values. With the burner set to produce a number 9 smoke in steady state the burner was operated with 5 minutes on/15 minutes of cumulative on-time. No change in the zirconium sensor output or soot fouling of the probe tip was observed. At the probes operating temperature any deposited soot would simply be burned off. In Figure 30, the response of this zirconium probe over cyclic operation is illustrated. Response time in this case is about $1 / 2 \mathrm{~min}$.

\section{Unheated Automotive Sensor}

As discussed in Section 3, the unheated zirconium oxide sensor was located in the upper region of the combustion chamber of a dry base steel boiler for testing. Figure 31 shows the output voltage from the sensor and the measured temperature near the sensor casing as a function of excess air at a burner firing rate of $0.75 \mathrm{gph}$. The sensor output voltage/excess alr relationship was found to be very repeatable even over a number of firing cycles. Excess air levels calculated using the sensor output voltage, the measured temperature, and the Nernst equation (see Section 2.2) did not agree with excess alr levels based on measured flue gas oxygen concentration. This comparison is illustrated in Figure 32. Several factors could be responsible for. this lack of agreement but perhaps the most significant is the assumption that the measured temperature matches the temperature of the zirconium oxide.

In Figure 33, the measured temperature and output voltage from this sensor are shown as a function of time following a startup. From this figure at 


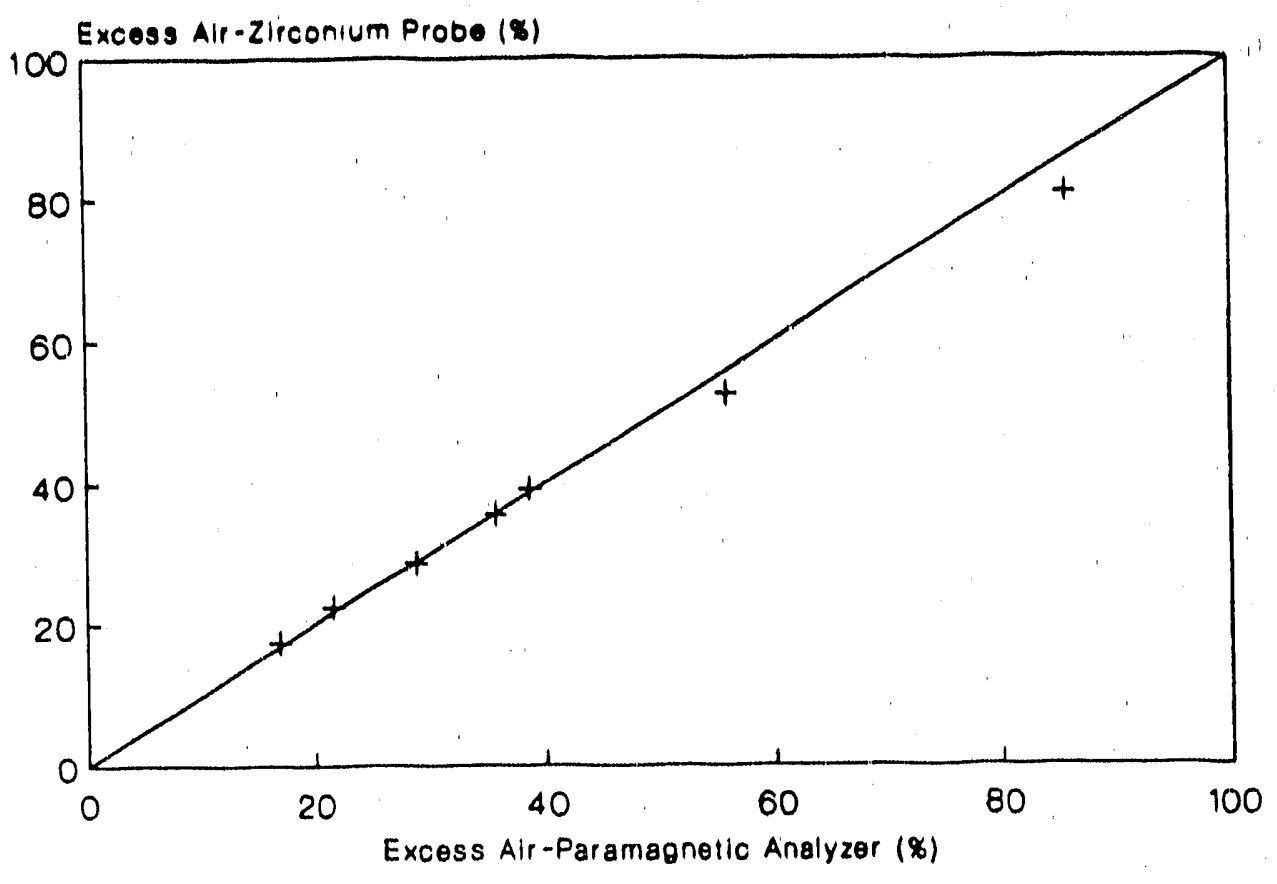

Figure 28. Excess air based on commerclal zirconium probe - comparison with paramagnetic analyzer.

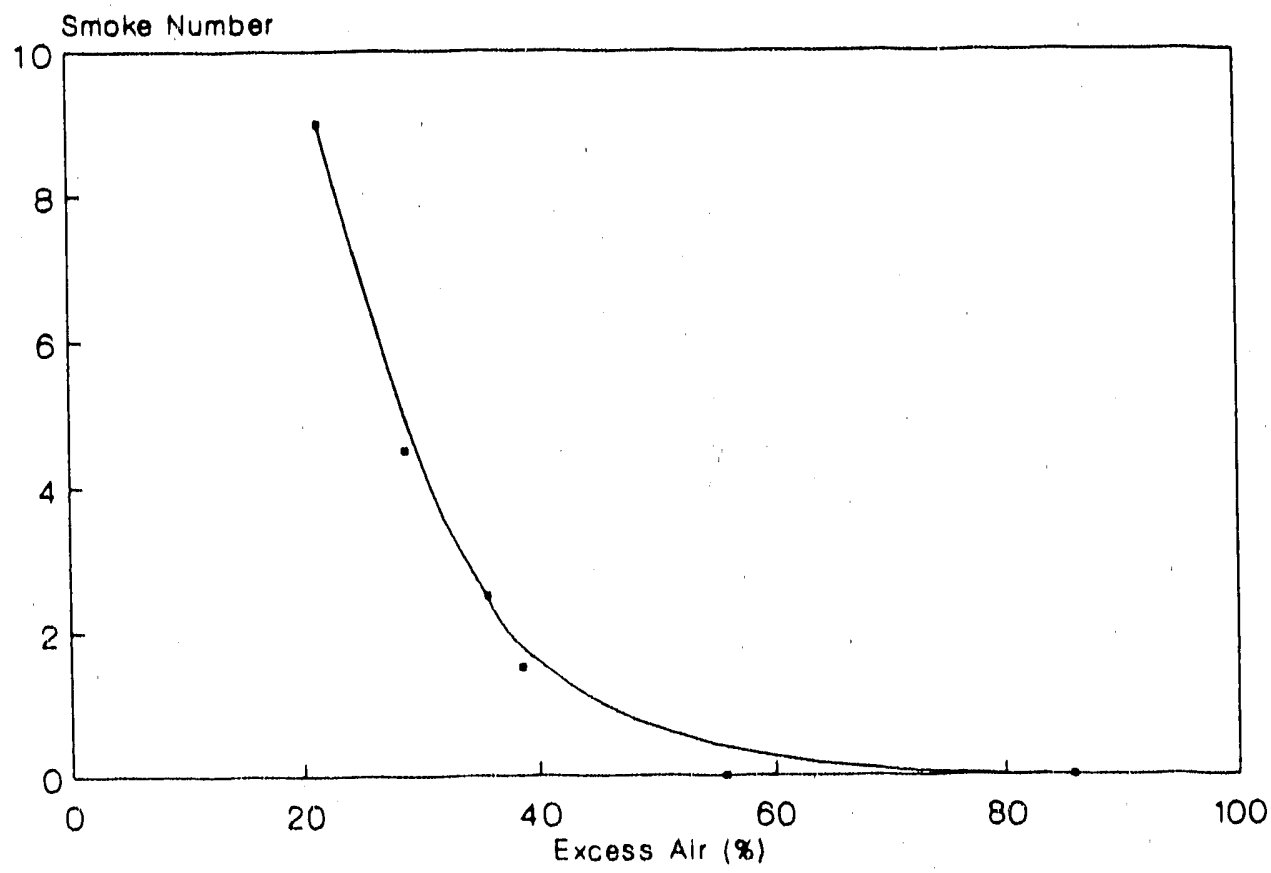

Figure 29. Smoke number vs. excess alr for test 1llustrated In Pigure 28. 


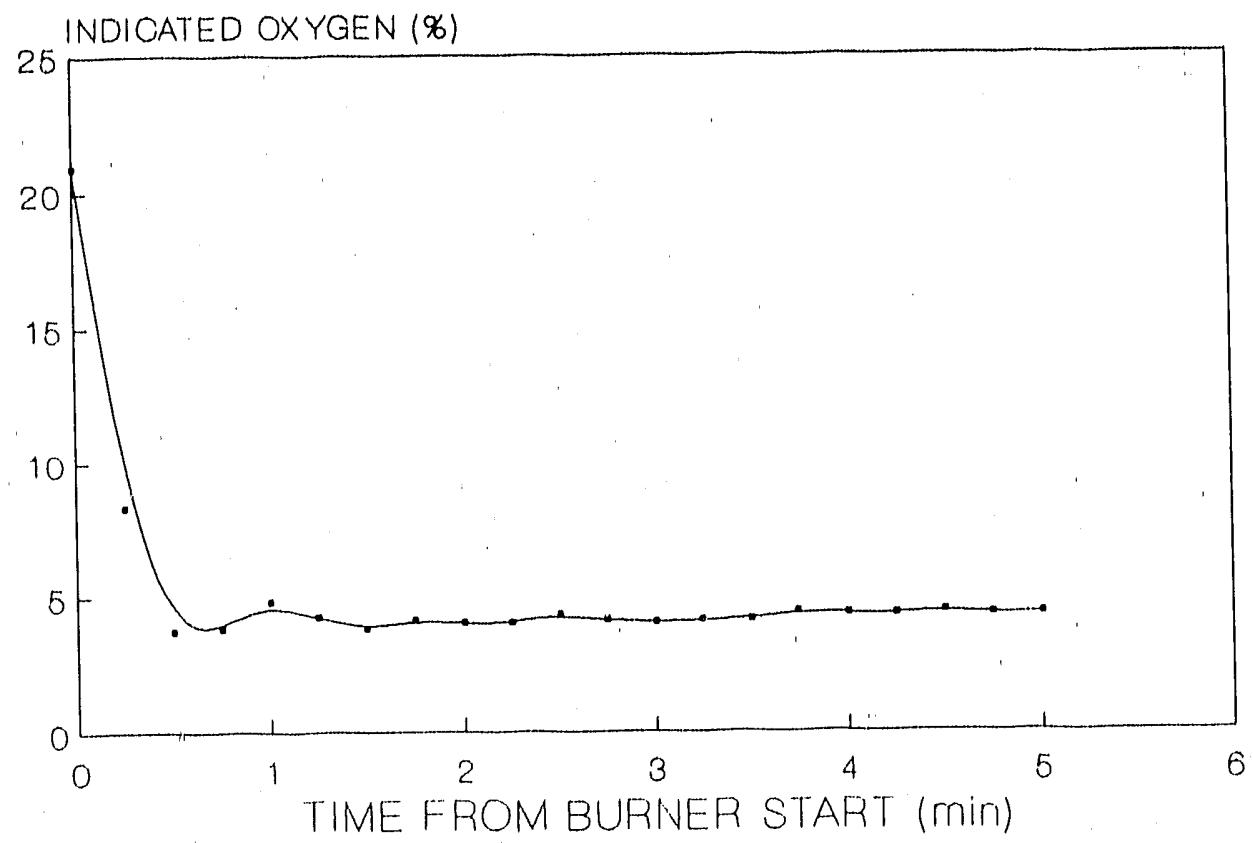

Figure 30. Commercial zirconium probe - indicated flue gas $\mathrm{O}_{2}$ over a firing cycle.

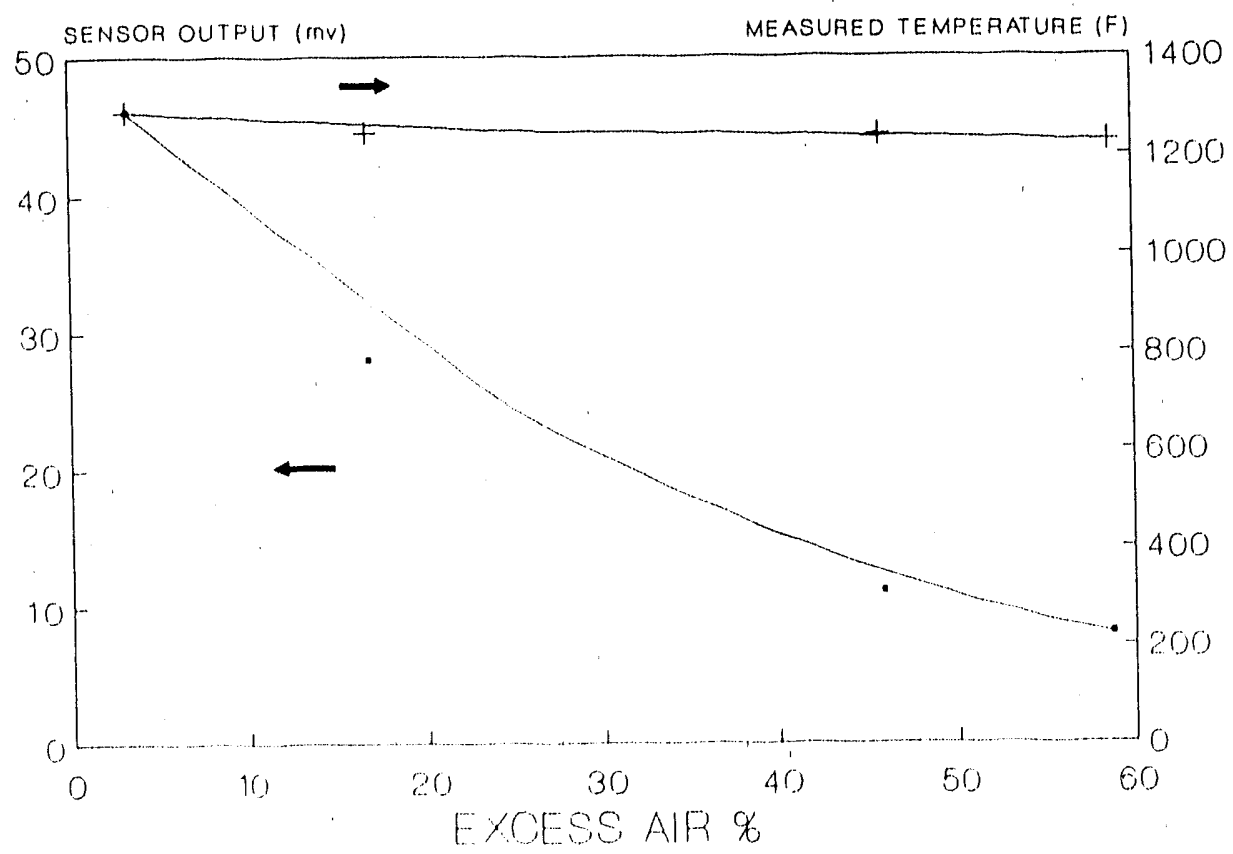

Figure 31. Unheated automotive type oxygen sensor - output signal and measured temperature as a function of excess a1r. 


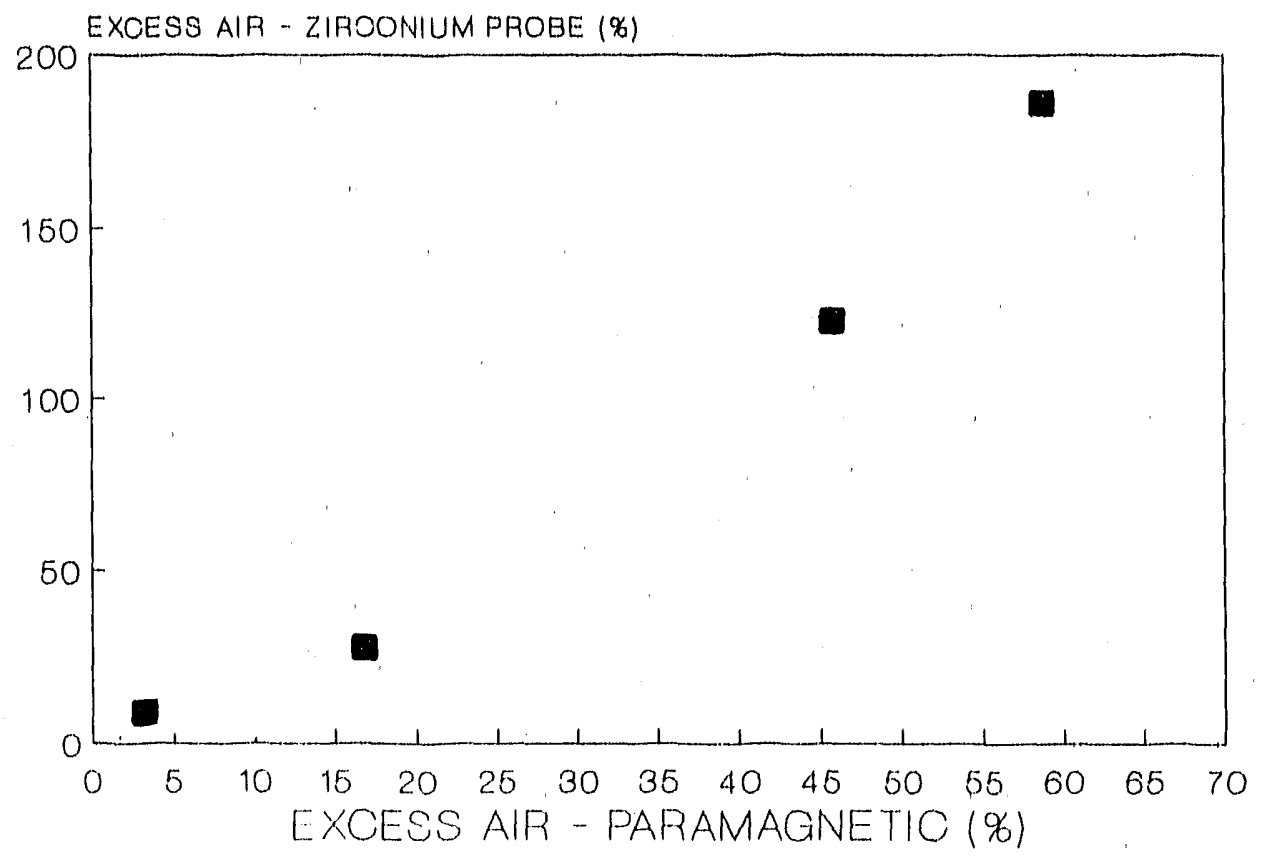

Figure 32. Excess air based on unheated automotive type sensor - comparison with paramagnetic analyzer.

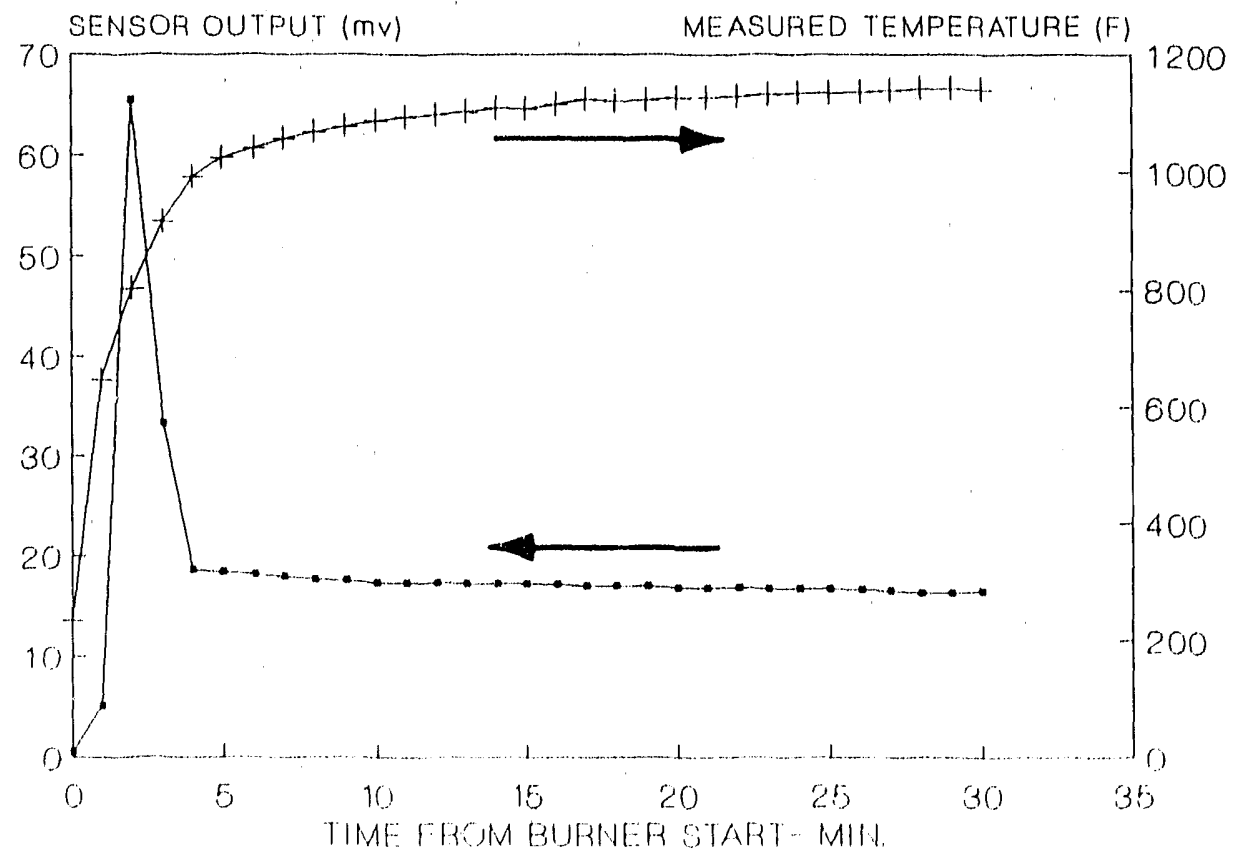

Figure 33. Unheated automotive type oxygen sensor - output signal and measured temperature over a firing cycle. 
least four minutes of firing are required before a useful signal is avallable from the sensor. This slow response would be a major impediment to the use of unheated sensors in this application.

\section{Heated Automotive Sensor}

As discussed in Section 3 the heated type automotive oxygen sensor was located in the flue plpe for testing. By varying the voltage of the supply power to the sensor heater from 0 to 24 volts 1 ta casing temperature could be controlled between the flue gas temperature (about $500^{\circ} \mathrm{F}$ ) and $1100^{\circ} \mathrm{F}$. In Figure 34 the output signal from the sensor ls shown, as a function of measured casing temperature at three excess afr levels in steady state. The best response to changes in flue gas oxygen is at the highest temperature. Below about $700^{\circ} \mathrm{F}$ the casing temperature is too low and the output is not useable. Figure 35 shows the excess alr levels calculated using the sensor output voltage, the measured casing temperature and the Nernst equation. While the agreement is not very good it is algnificantly better than for the unheated sensor In the combustion chamber (see Figure 32). As in the case of the unheated sensor it is likely that the measured casing temperature is different than the temperature of the zircontum oxide.

Flgure 36 111ustrates the response of the heated sensor over a firing cycle. Relative to the lower cost, unheated sensor in the combustion chamber the heated sensor in the flue has a much shorter response time. For control purposes this response would certainly be acceptable.

Some tests using the heated automotive oxygen sensor were also performed using the prototype vaporizing ofl burner described in Section 3. Relative to conventional retention head burners this burner is capable of operating at very low excess alr levels without producing smoke. In Figure 37 the smoke number/excess atr and co/excess atr relationship for this burner are llilustrated. Figure $3 y$ shows the vartation in sensor output over the same excess atr range. For this burner there is a very signiflcant change in output as the "smoke 11mit" is passed. In Flgure 39 the excess air calculated from the zirconiuin oxide sensor output (heated to $1100^{\circ} \mathrm{F}$ ) is compared with that determined from the paramagnetic analyzer $\mathrm{O}_{2}$ reading. At $\mathrm{O}_{2}$ levels below about $14 \%$, which is the point at which smoke and CO begins to become excessive, the zirconium sensor indicates much less $\mathrm{O}_{2}$ than the paramagnetic. At this condition the oxygen concentration at the surface of the zircontum sensor ts lower than for the bulk flue gas because of oxidation of the products of incomplete combustion on the hot sensor surface. For control purposes this is an advantage, amplifying the change in output when the smoke 11 intt has been passed.

\subsection{Measurements of Flane Optical Emissions}

4.5.1 Conventional Retention Head Burner Flame, Vlewed from the Burner Housing.

Plgure 40 shows emission spectra measured with a 120011 nes/mm grating covering the vistble range (450-700 nanometers (nu)) and a part of the UV for a retention head burner. The system was flred at $1.0 \mathrm{gph}$ with excess alr levels ranging froin $17 \%$ to $54 \%$ (smoke numbers $y$ to 0 ). The emission spectra shown are essentially litke a black body enission from a luminous flame. becreasing excess atr increases flame enlssivity and results in tncreased intensity of emitted radiation. 


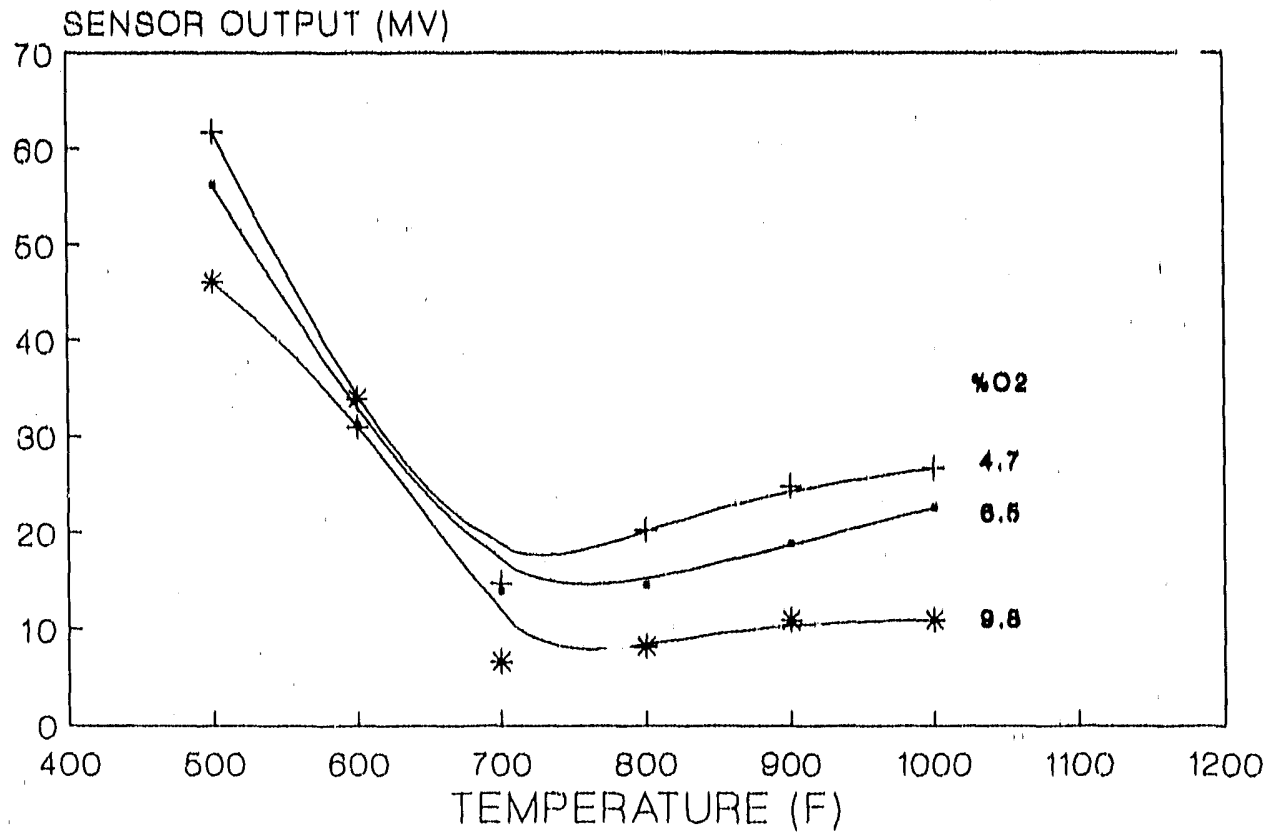

Figure 34. Heated automotive type oxygen sensor - output signal as a function of sensor temperature and $\mathrm{O}_{2}$ (paramagnetic analyzer).

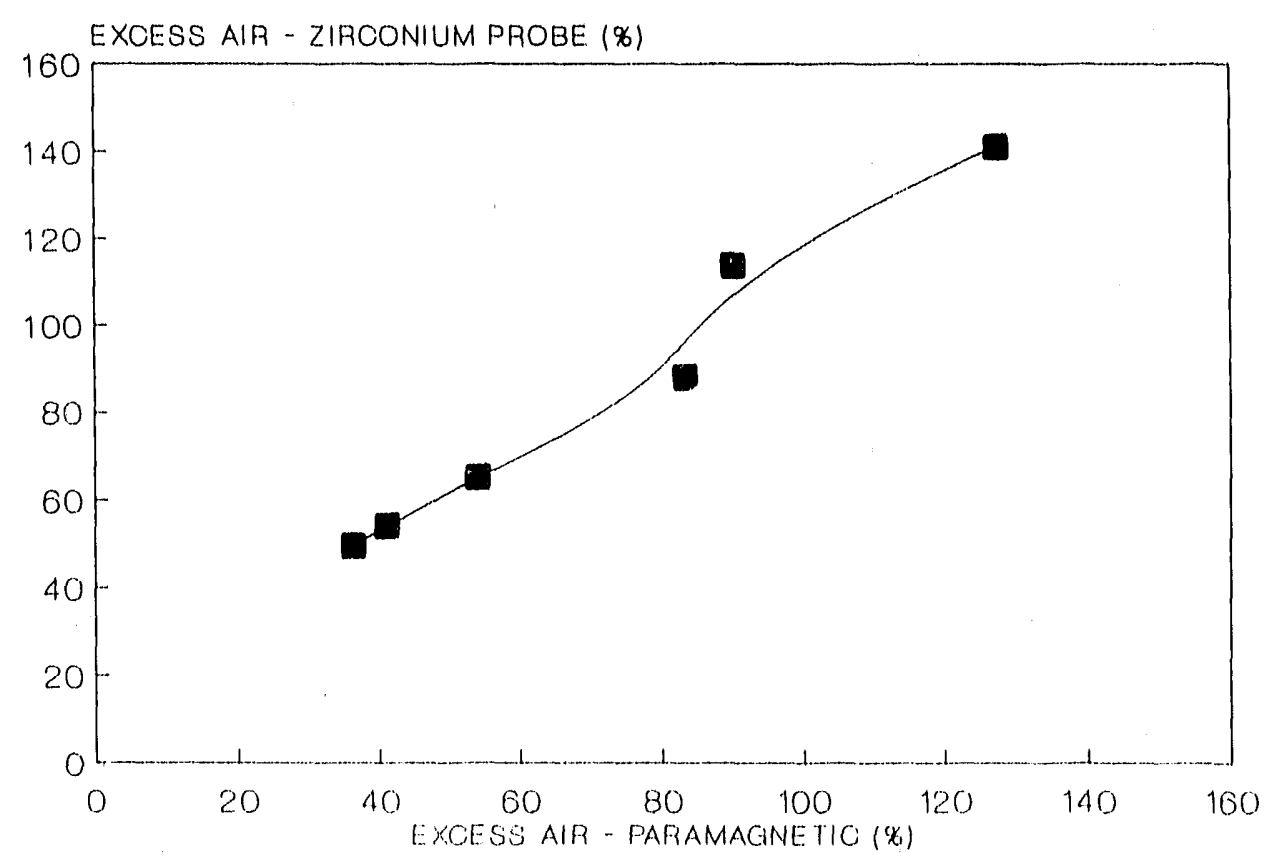

Figure 35. Excess alr based on heated automotive type oxygen sensor at $1100^{\circ} \mathrm{F}$ - comparison with paramagnetic analyzer. 


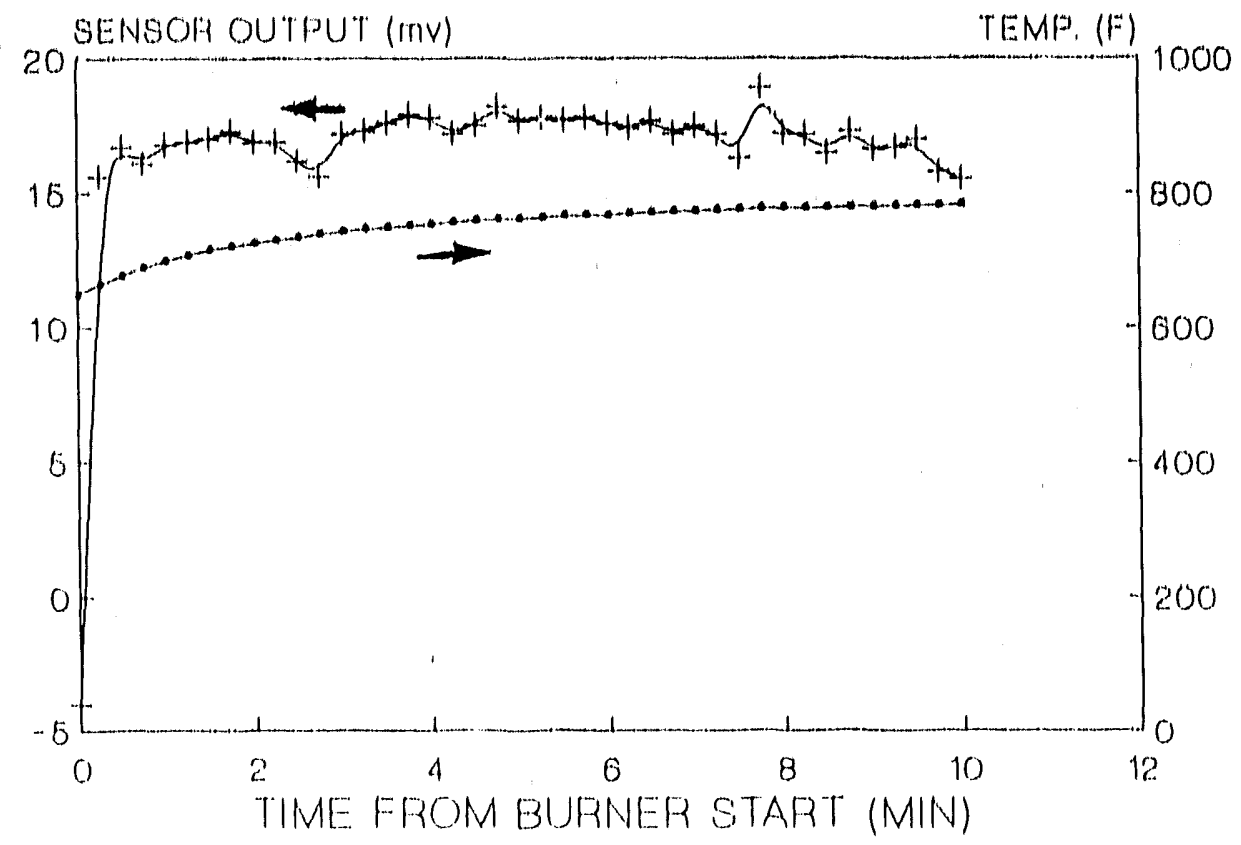

Flgure 36. Heated automotive type oxygen sengor - output algnal and meagured temperature over a firlng cycle.

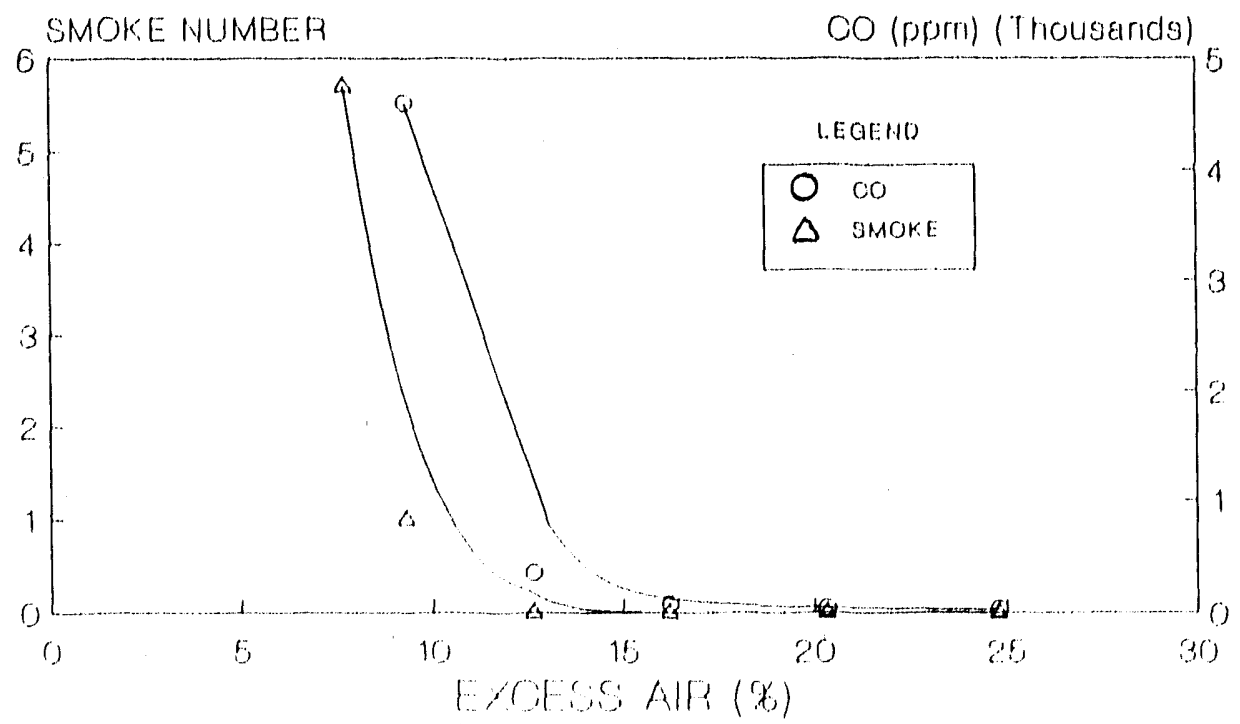

Flgure 37. Measured smoke number and CO emissions over a range of excess air levels. Prototype vaporizing oll burner. 


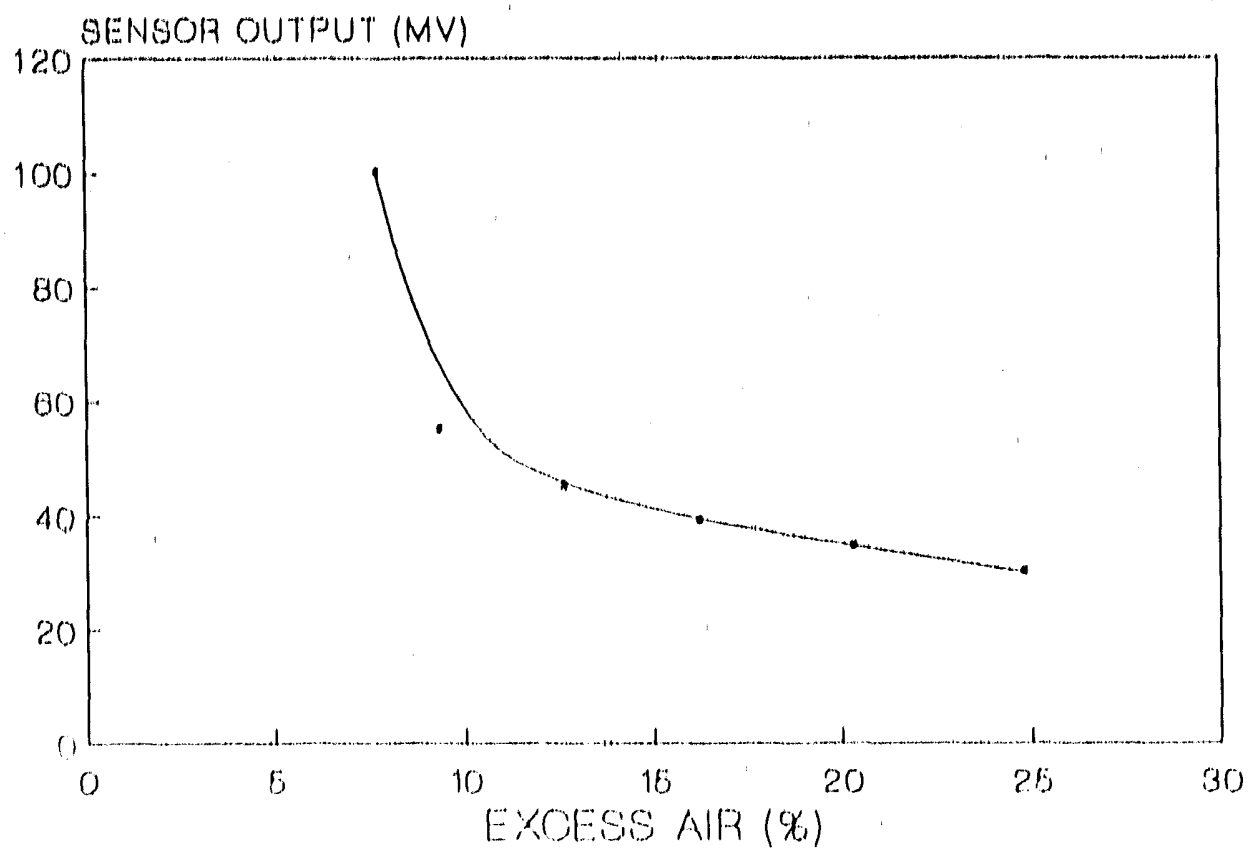

Flgure 38. Heated automutive type oxygen sensor i- output. algnal as a function of excess alr in prototype vaportzing ofl burner.

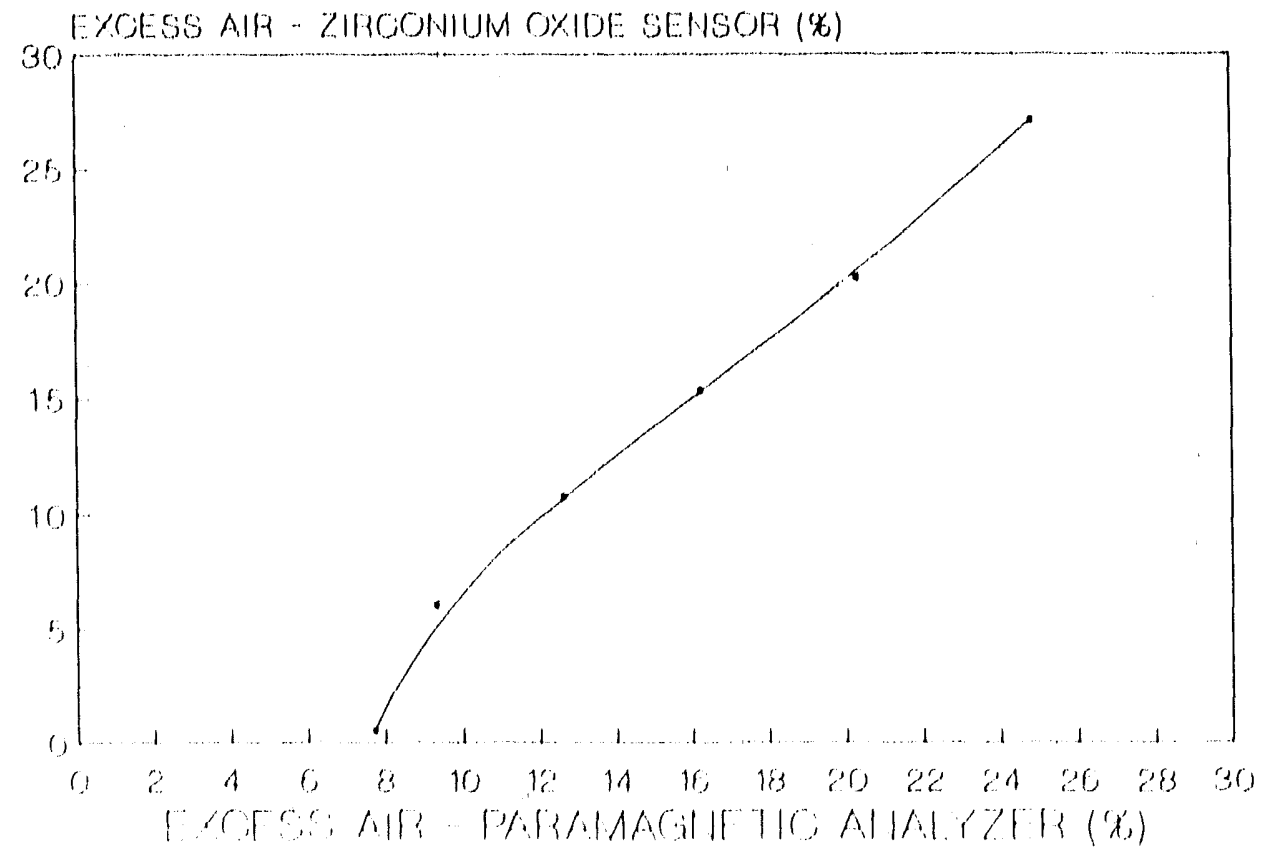

Figure 39. Excess alr based on heated autiomotive type oxygen senoor In prototype vaporlalng oll burner comparison with paramagnetic analyzer. 

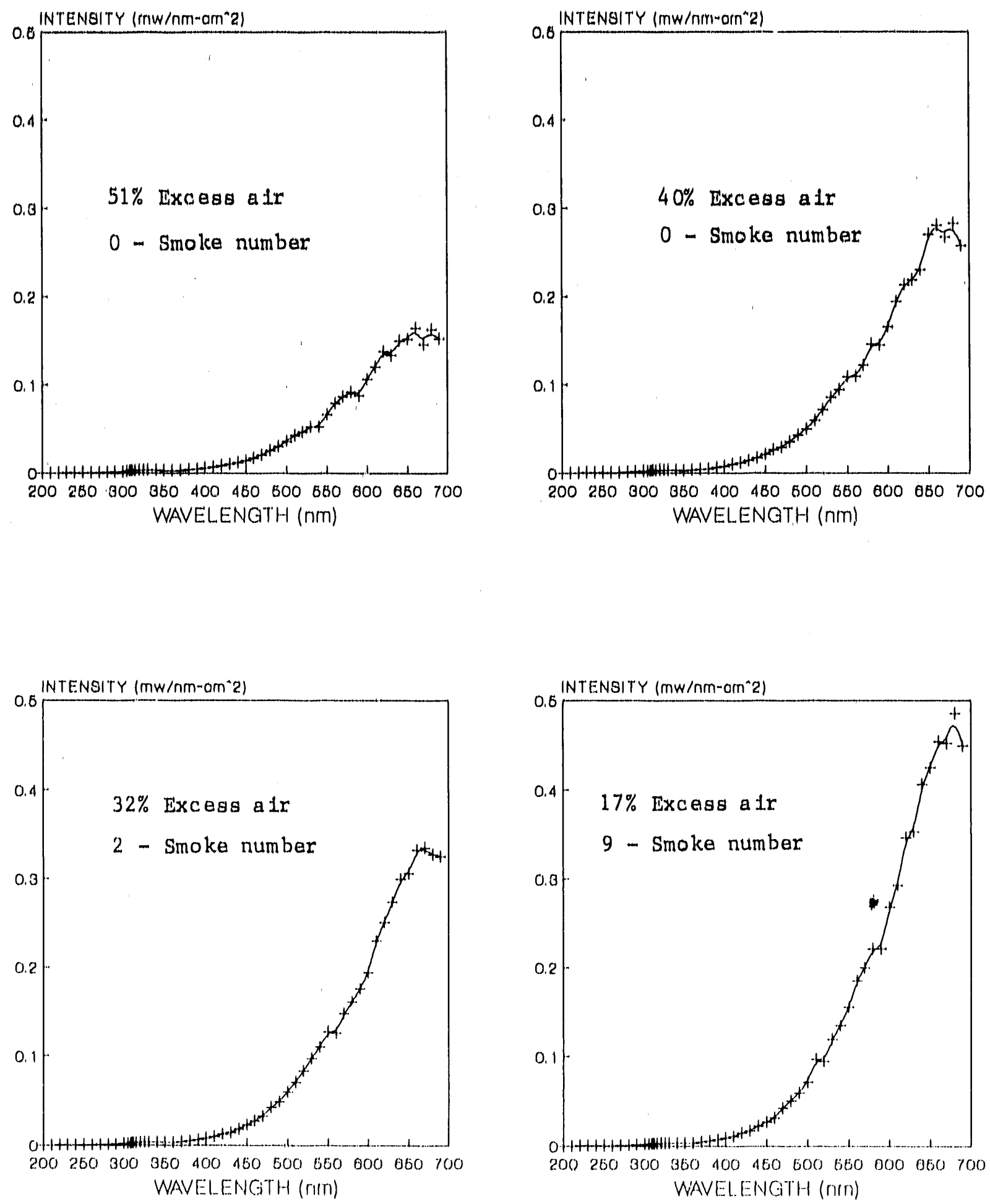

Figure 40. Flame optical emlssion spectra over the vialble range (450-700 nm) and a part of the UV-retention head burner at four excess alr levels. 
In Figure 41 the emiasion Intenglty at selected wavelengths la plotted as a function of excess atr. The decrease in intensity with increasing excess alr to more olgniflcant at higher wavelengtho. This lo further 1llugtrated in Figure 42 which shows the ratio of Intensity at $600 \mathrm{~nm}$ to intengity at $400 \mathrm{~nm}$ as a function of excess afr. This trend would be constatent with an increase of source temperature with excess alr (black body asatumption). The two wavelengths chosen $(600 / 400)$ are near opposite ends of the visible wavelength range and so their ratio is roughly an indlcator of "color."

Figure 43 shows emission spectra over the ultraviolet range from 200 to $450 \mathrm{~nm}$. In addition to an extension of the continuum emisoion observed in the visible (F1g. 40) there to a clear peak due to emlsaton from oH at about 310 nm. Figure 44 shows the variation of the emlasion at selected wavelengths in the UV with excess atr. Because of the very wide spread in values over this range, three intensity scales are used. Unilke the continuum emisolun the $\mathrm{OH}$ emission does not decrease algniflcantly with increasing excess atr. Thds suggests that the ratio of a continuum signal to the OH olgnal would be a useful Indicator of atr/fuel ratto. Relative to almple continuum intengity this would have the advantage of a reduced sensitivity to partial sightpath blockage and sensor misalignment.

An Ideal system for monttoring flame quality would give an output dependent only on smoke emissions and at least somewhat Independent of other parameters. A system which has a different oet polnt depending upon firing rate or which is affected by smald vartations in fuel quality would be less interesting than one which lo undversal. Towards evaluating the usefulness of an optical flame quality signal, emisgion spectra were obtalned over the UV and vistble ranges as a function of excess atr for a wide vartety of cond tions. This includes:

firing with new 0.75 and $0.50 \mathrm{gph}$ nozzles

- flring with a 0.85 nozzle whlch had been removed from a home and was apparently fouled.

o flring with a 1.25 gph nozzle with ofl pump pressure reduced to 70 po1.

- a 1 gph nozzle fired with No. 4 oll.

0 a 1 gph nozzle fired with blends of No. 2 and No. 4 olis.

The nozzles used in these tests were not optinized for this burner/chanber situation but were selected at random. The fouled nozzle was rated at 0.85 but actually delivered $0.65 \mathrm{gph}$ due to interference from the heavy coke deposits. The \#4 o.1 was tested as an extreme case of degraded fuel quality. In the case of the 1.25 gph nozzle at reduced pressure the intention was to have poor atomization without a severely misohaped flame.

In tests with the \#4 o11 the smoke number changed from 1 to 6 with the introduction of the lower grade ofl and excess atr changed aldghtly. Optical 


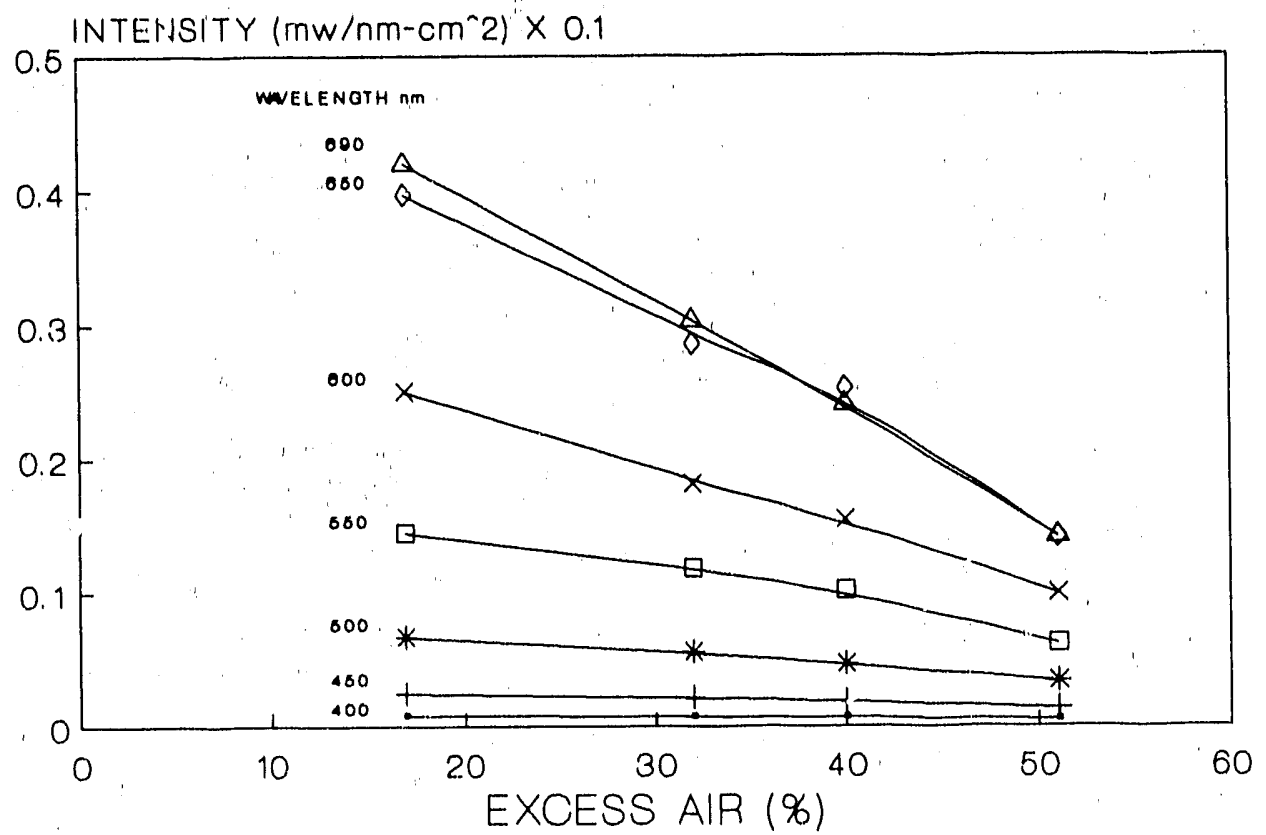

Figure 41. Flame optical emission intensity as a function of excess air at selected wavelengths in the vistbleretention head burner.

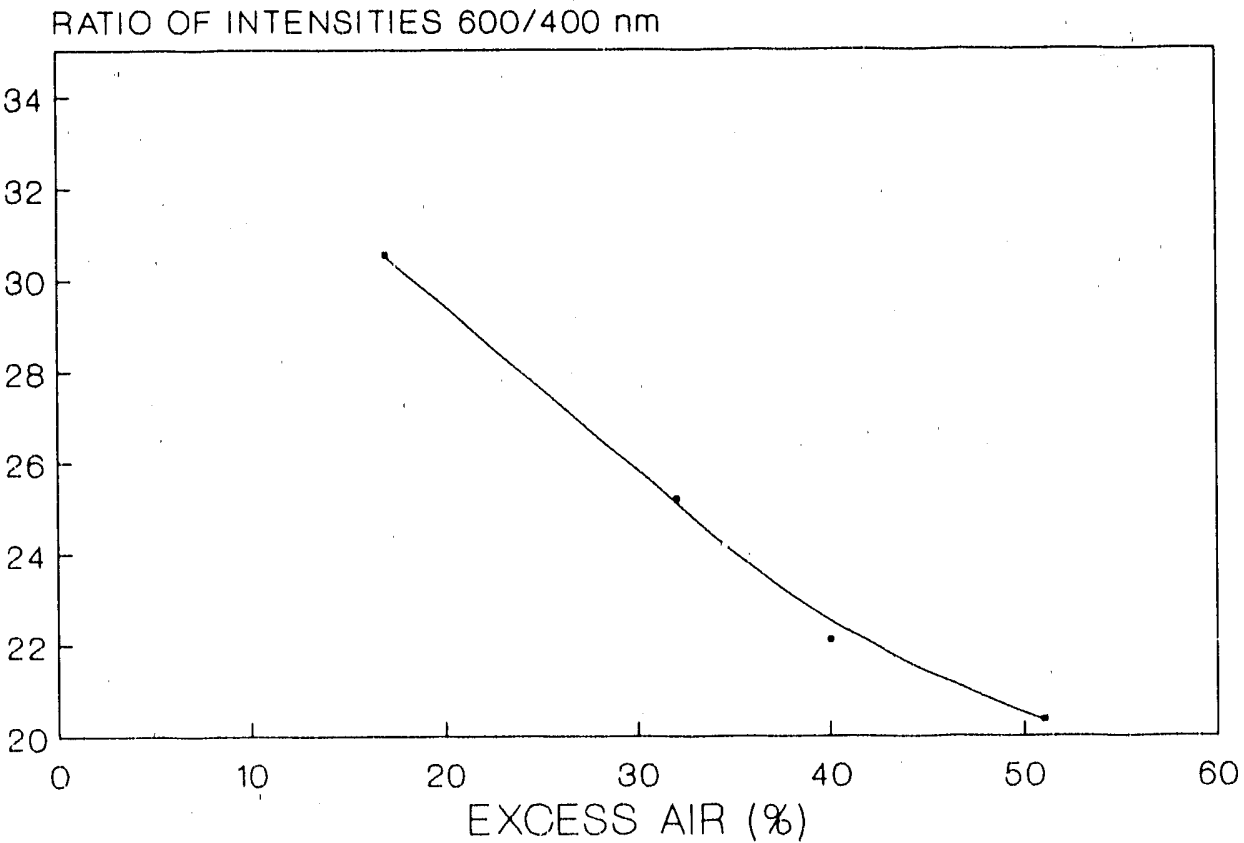

Figure 42. Ratio of optical emission intensities at 600 and $400 \mathrm{~nm}$ as a function of excess air - retention head burner. 

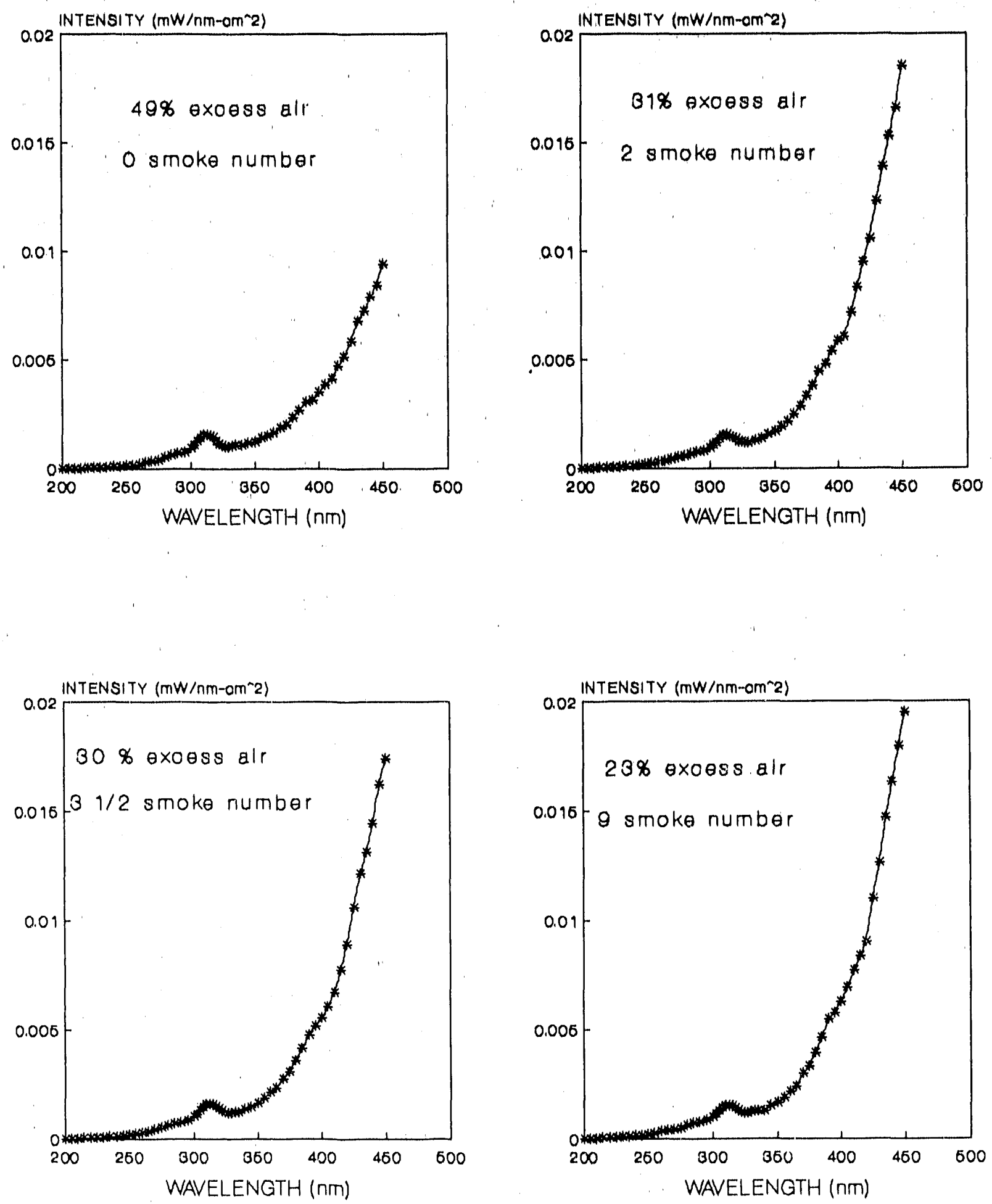

Figure 43. Flame optical emission spectra over the ultraviolet range (200-450 nm) - retention head burner at four excess air levels. 

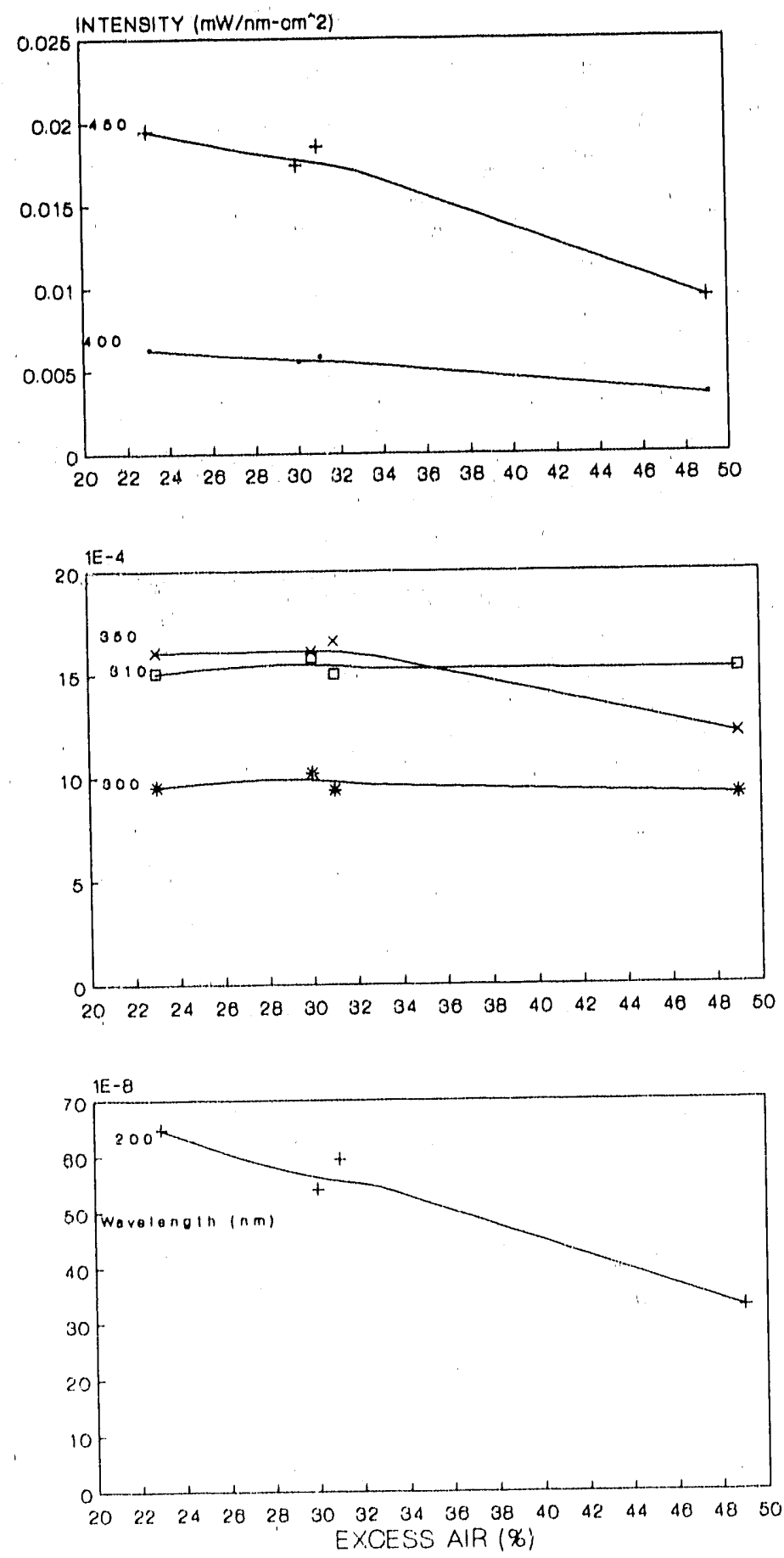

Figure 44. Flame optical emission intensity as a function of excess air at selected wavelengths in the ultraviolet (note - three scales used for intensity). 
emission measurements were made over the range 200-450 nm. The continuum signal intënsity decreased by $1 / 2$ indicating a very significant change in flame position. No significant change in the shape of the optical emission curve was observed.

As Table 1 shows, the fuel blend with the lowest content of No. 4 oil $(10 \% \# 4 / 90 \% \# 2)$ had a carbon residue only slightly greater than the ASTM 1imit while API gravity and viscosity are within the specifled limits. The blend with the highest content of No. 4 oil $(30 \% \# 4 / 70 \%$ \#2) was outside of the ASTM limits for carbon residue, API gravity and viscosity of No. 2 oll. In tests, the oil burner pump suction was changed to each blend in turn and the burner excess air setting was unchanged. Relative to operation with $100 \%$ No. 2 oil., the smoke numbers increased only slightly (from "trace" to about No. 1 Bacharach) with the lowest quality blend $(30 \%$ \#4/70\% \#2). No significant optical changes were observed.

The $1.25 \mathrm{gph}$ nozzle operated at reduce pressure was found to have a smoke/excess air curve and optical emissions essentially identical to those from the $1.0 \mathrm{gph}$ nozzle.

Table 1. Fuel Properties

\begin{tabular}{|c|c|c|c|}
\hline Fue1 & Carbon Residue-wt\% & $\begin{array}{l}\text { API Gravity } \\
\text { at } 60^{\circ} \mathrm{F}\end{array}$ & $\begin{array}{c}\text { Viscosity, Centistokes } \\
\text { at } 100^{\circ} \mathrm{F}\end{array}$ \\
\hline No. 2011 & $<0.05$ & 34.0 & 2.5 \\
\hline No. 4011 & 4.00 & 19.2 & 108.2 \\
\hline \multicolumn{4}{|l|}{ Fue1 Blends: } \\
\hline $10 \%$ 非, $90 \%$, 非 & 0.40 & 32.4 & 2.9 \\
\hline $20 \%$ 非 $4,80 \%$ 非 & 0.80 & 31.0 & 3.4 \\
\hline $30 \%$ 非 $4,70 \%$ 非 & 1.20 & 29.3 & 3.9 \\
\hline $\begin{array}{l}\text { ASTM Limits } \\
\text { for No. } 2 \text { oil }\end{array}$ & .35 tnax & $30 \mathrm{~min}$ & $2.0-3.6$ \\
\hline
\end{tabular}

Figure 45 shows the smoke number/excess alr relationship for the 0.5 , 0.75 and $1.0 \mathrm{gal} / \mathrm{hr}$ nozzles and the fouled $0.85 \mathrm{gph}$ nozzle and indicates that the range in performance was very broad. In Figure 46 intensity at $450 \mathrm{~nm}$ for the four rozzles is shown plotted against excess air. This certainly shows that this intensity is a poor indicator of the absolute excess air level. Figure 47 shows the intensity at $450 \mathrm{~nm}$ against smoke number and Figure 48 shows the ratio of intensities at 450 and $310 \mathrm{~nm}$ against smoke number. As discussed previously the signal at $450 \mathrm{~nm}$ is indicative of the continuum intensity and the $310 \mathrm{~nm}$ signal is due to $\mathrm{OH}$ and falrly independent of excess air and smoke number. 


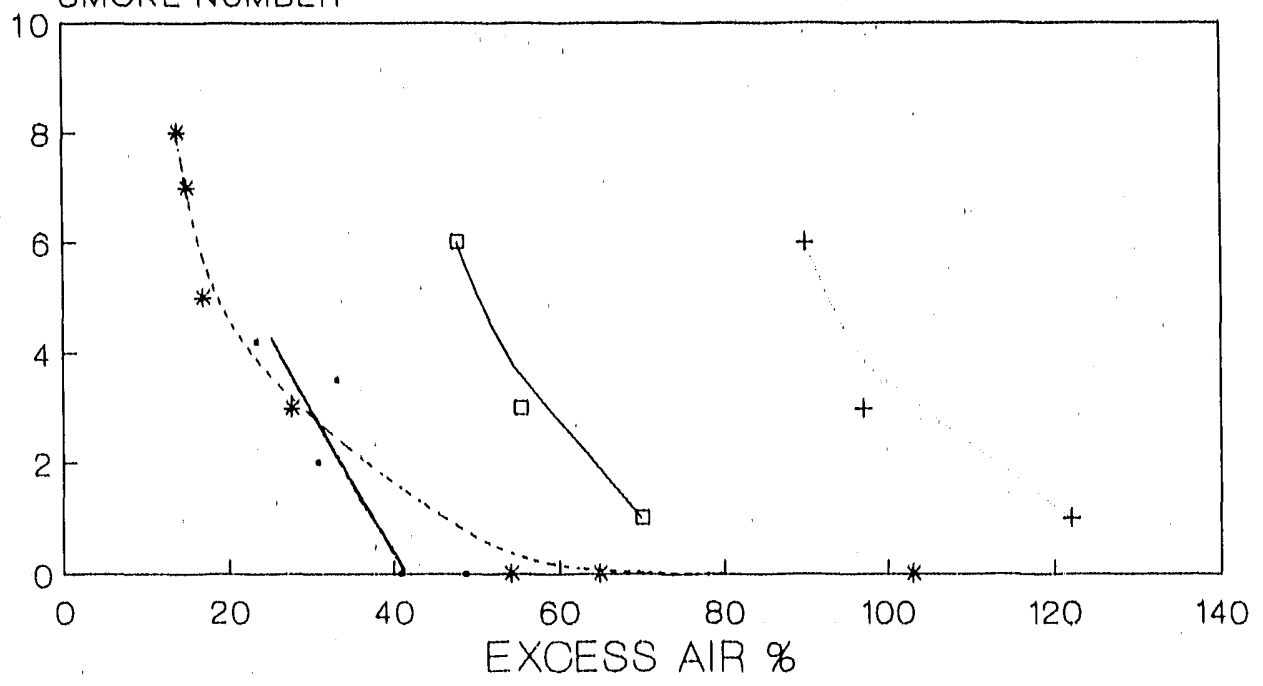

-. $1.0 \mathrm{GPH}+0.5 \mathrm{GPH} \quad * \cdot 0.75 \mathrm{GPH} \quad-$ E- 0.86 FOULED

Figure 45. Smoke number over a range of excess air levels retention head burner with four nozzles.

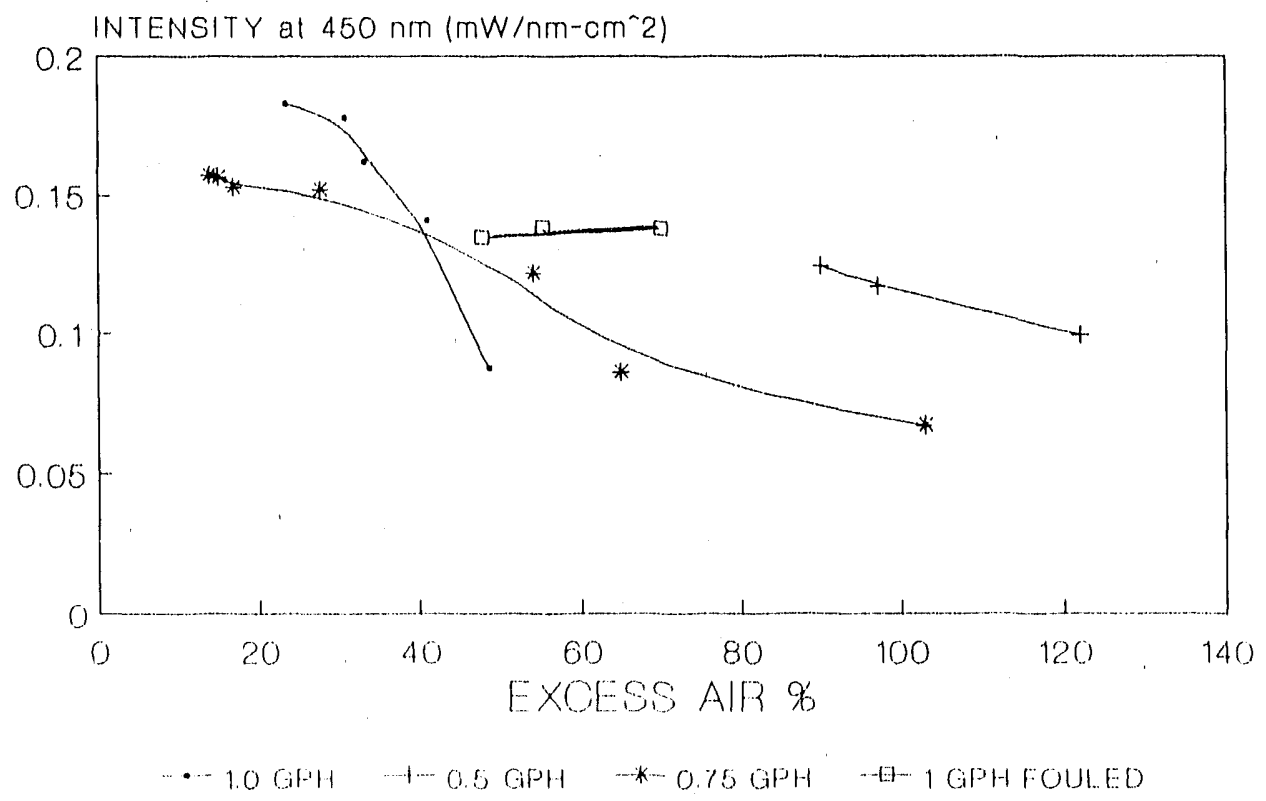

F1gure 46. Flame optical emission intensity at $450 \mathrm{~nm}$ as a function of excess air - retention head burner with four nozzles. 
The results in Figures 47 and 48 can be used to illustrate two possible control schemes. A control system might have a set point at a fixed value of continuum intensity. Based on Figure 47 this might be $0.1 \mathrm{~mW} / \mathrm{nm}-\mathrm{cm}^{2}$ at $450 \mathrm{~nm}$ for example (note - in practice a much broader wavelength indicator of continuum intensity would likely be used). As an alternative, a fixed ratio of continuum to $O H$ intensity might be used. A value of the $450 / 310$ ratio of 8 might be used for this based on Figure 48. In Figure 49 the smoke number/excess atr relationship for these burners, is agaln plotted with markers added to show the setpoint which would reault from both of these control approaches. Both methods produce a setpoint reasonably close to the excess air which gives "trace" smoke. No point 18 shown for the $0.85 \mathrm{gph}$ nozzle with the $450 \mathrm{~nm}$ intensity only because the setpoint signal chosen for this example was not reached over the alr/fuel ratio explored.

In Flgure 42 it was shown that, for a given nozzle, the ratio of intensities at 500 and $400 \mathrm{~nm}$ varies smoothly with excess air. For the four nozzles it was attempted to use this ratio as an Indicator of smoke. Unlike the intensity at $450 \mathrm{~nm}$ and the $450 / 310 \mathrm{~nm}$ intensity ratio, the $600 / 400 \mathrm{~nm}$ intensity ratio was found not to be consistent or at all useful.

As discussed in Section 3 some broadband measurements were also made using a cadmium sulfide photoconductor, a lead selenide photoconductor and a simple thin foll thermocouple target. Results at a firing rate of $0.75 \mathrm{gph}$ are shown in Figure 50. In this case any of these measures shows a good sensitivity to excess air.

Measurements using both the 1200 and the 600 lines/mm gratings at the same combustion condition were made using the conventional retention head burner flred into the boller lllustrated in Figure 4. This provided results which cover a broader spectral range in the visible and near infrared (500 to 1100 microns). With these results apparent flame temperatures were estimated based on the ratio of intensities at 1000 and $600 \mathrm{~nm}$. This temperature estimate assumes that the flame emission follows the black body laws.

Results are shown for different excess air levels in Figure 51 with the stock combustion chamber in place and in Figure 52 with chamber removed. For each case the intensity ratio $(1 / .6 \mathrm{micron})$ and corresponding apparent flame temperatures are shown. These results do not show a consistent trend of apparent flame temperature (or color) with excess air over this range which could be used for control purposes. As expected, removal of the chamber reduces the apparent flame temperature.

In Figure 53 the results of temperature measurements along the chamber axis with and without the refractory iner are shown. These were made using the suction pyrometer described in section 3.5. The temperatures shown in this figure are significantly lower than those calculated based on the optical emissions. To a large degree this is due to the black body law assumption which was used in calculating the apparent optical flame temperatures. In using the black body law, it is assumed that the emissivity of the oil flame is independent of wavelength. Actually emissivity decreases with increasing wavelength over this range [28]. Both nethods, however, show the reduced flame temperature with the removal of the refractory liner. It is 


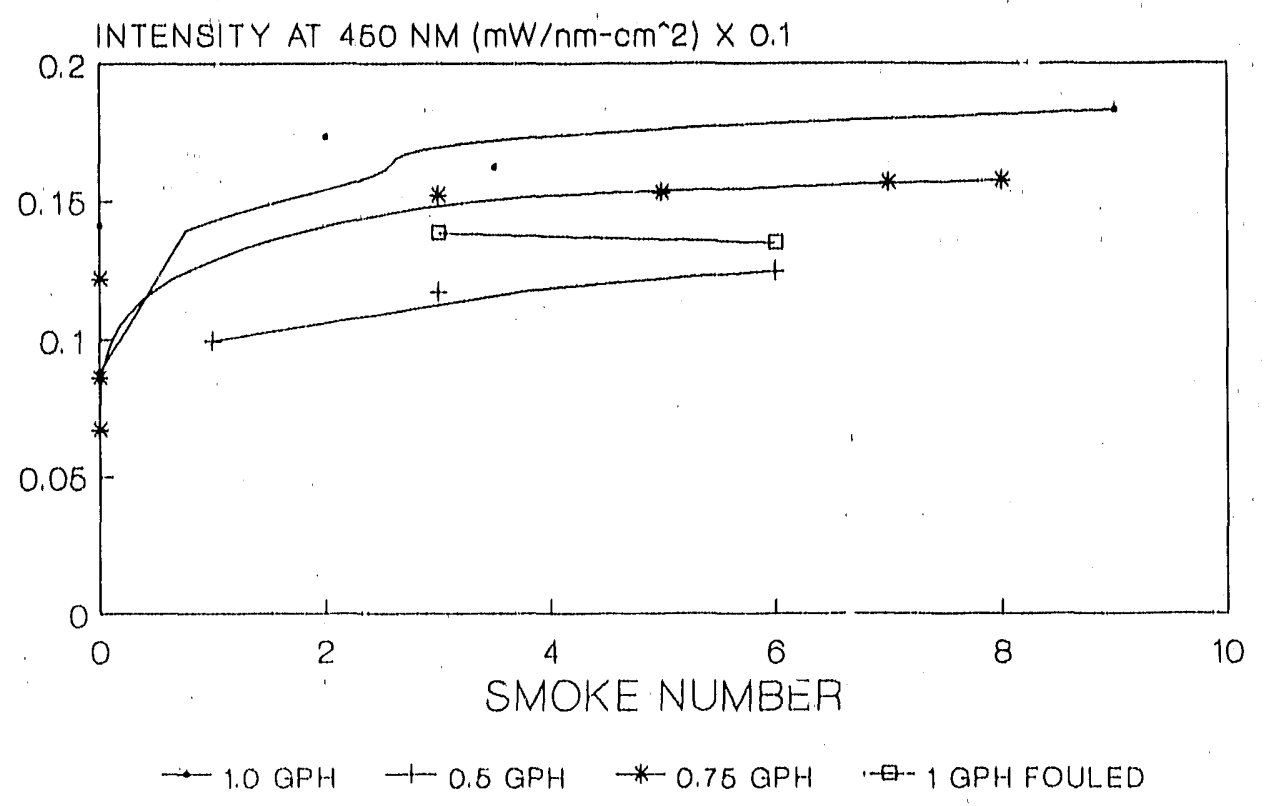

Figure 47. Flame optical emission intenstty at $450 \mathrm{~nm}$ as a function of smoke number - retention head burner with four nozzles.

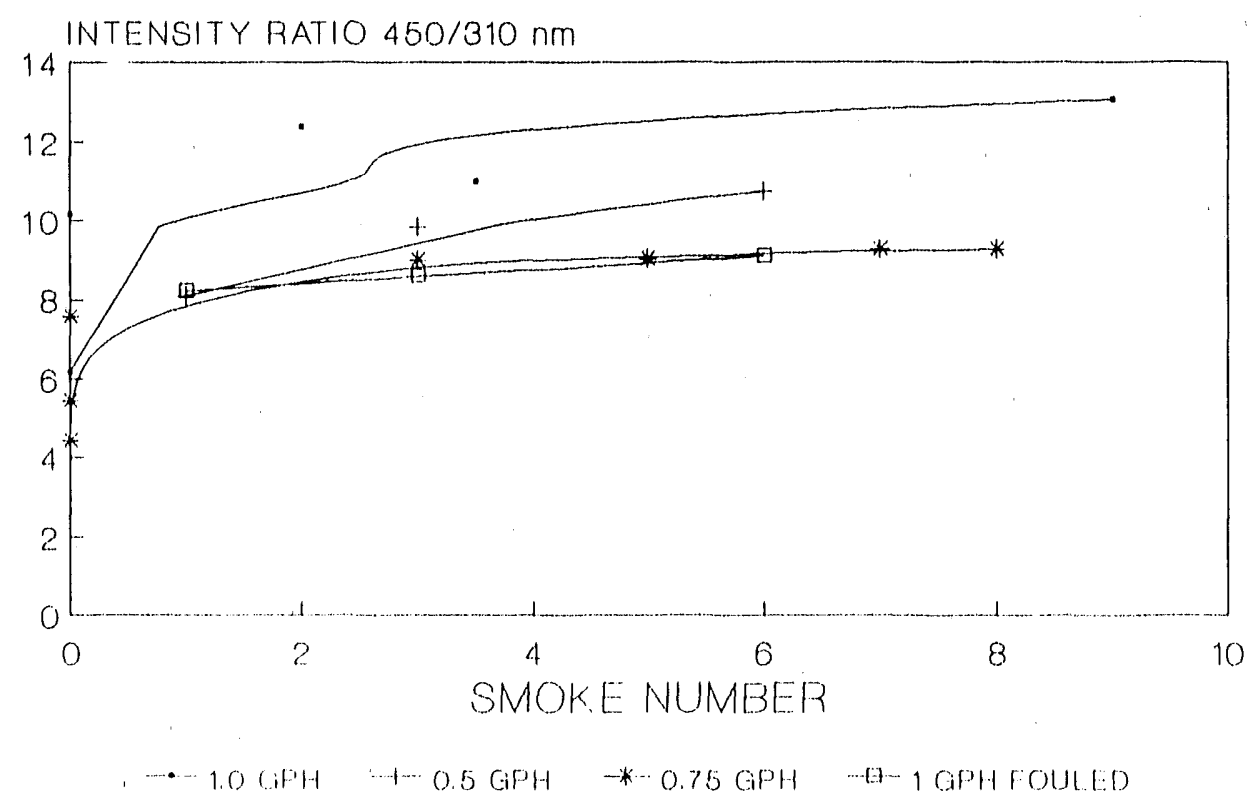

Figure 48. Ratio of optical emission intensities at 450 and 310 nin as a function of smoke number - retention head burner with four nozzles. 

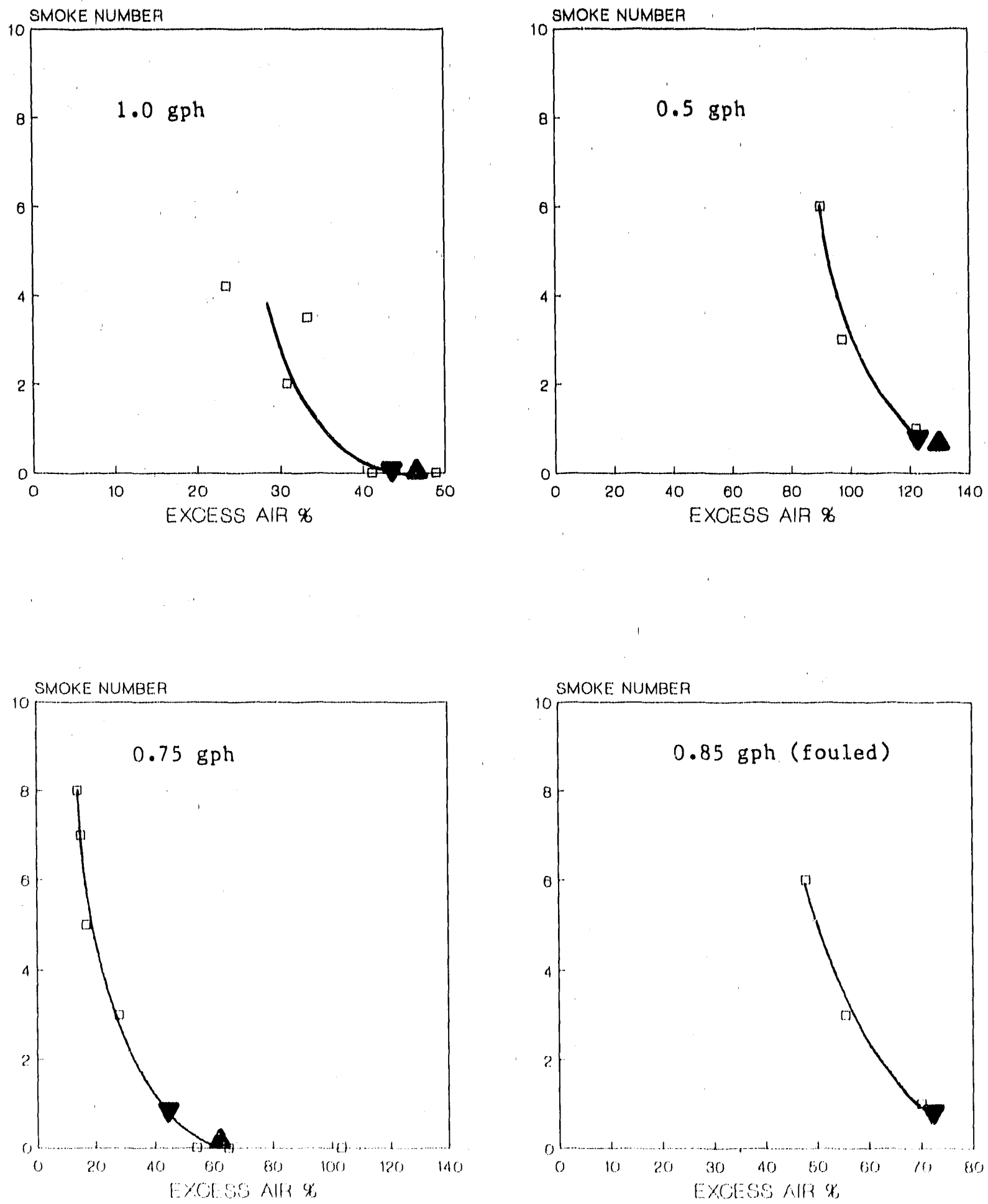

Figure 49. Excess air setpoints based on continuum emtasion at $410 \mathrm{~nm}(\boldsymbol{A})$ and ratio of intenstities at 410 and $310 \mathrm{~nm}$ $(\nabla)$ - retention head burner with four nozzles. 

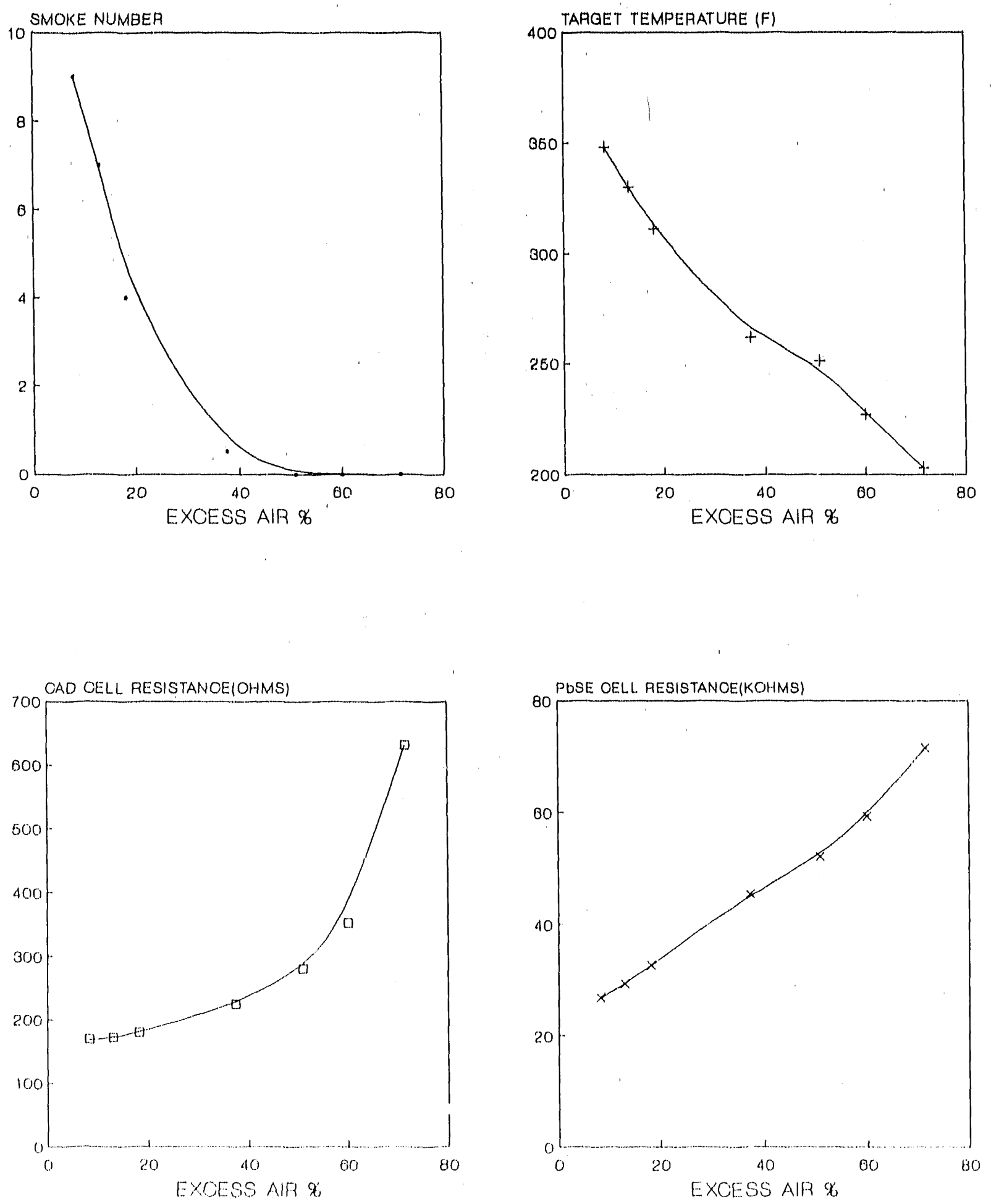

Flgure 50. Smoke number and response of broad band sensors vs. excess alr - retention head burner. 

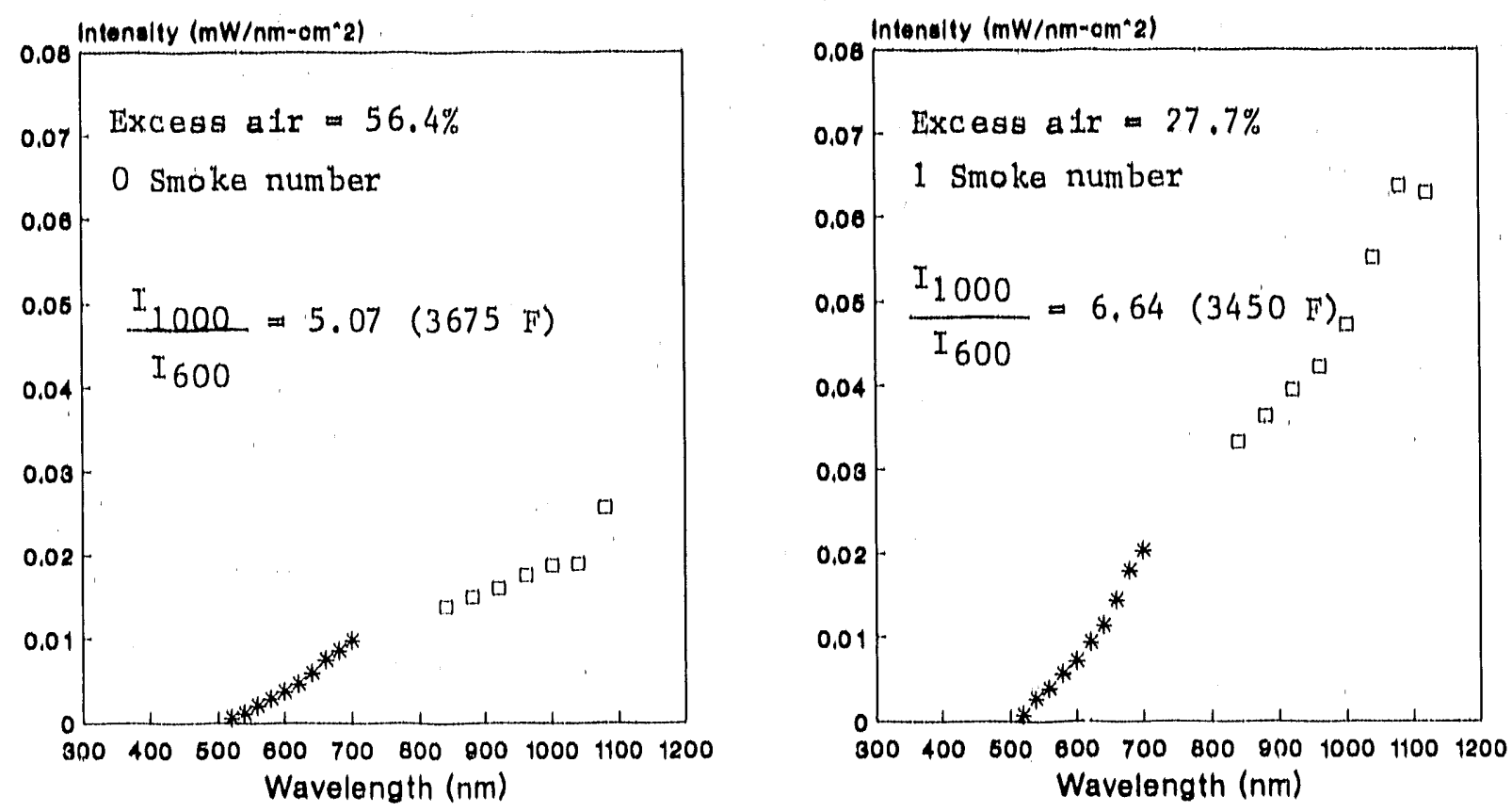

* $=12001$ ines/mm grating

口 $=6001$ Ines $/ \mathrm{mm}$ grating
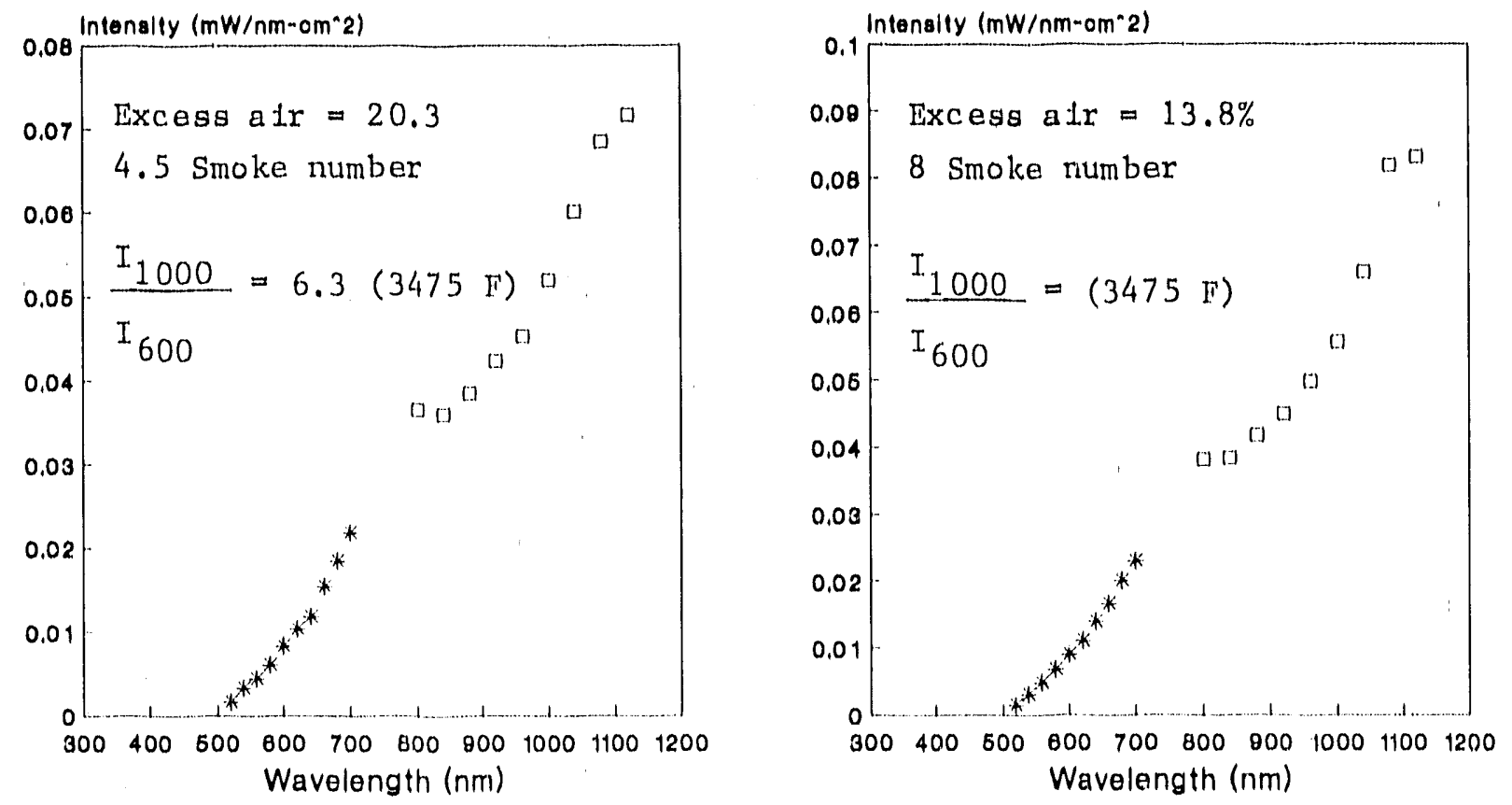

Figure 51. Optical Emission Spectra With a Combustion Chamber. Note - Temperatures in parenthesis indicate "apparent" flame temperatures using black body assumption and ratio of 1 ntensities at 1000 and $600 \mathrm{~nm}$. 

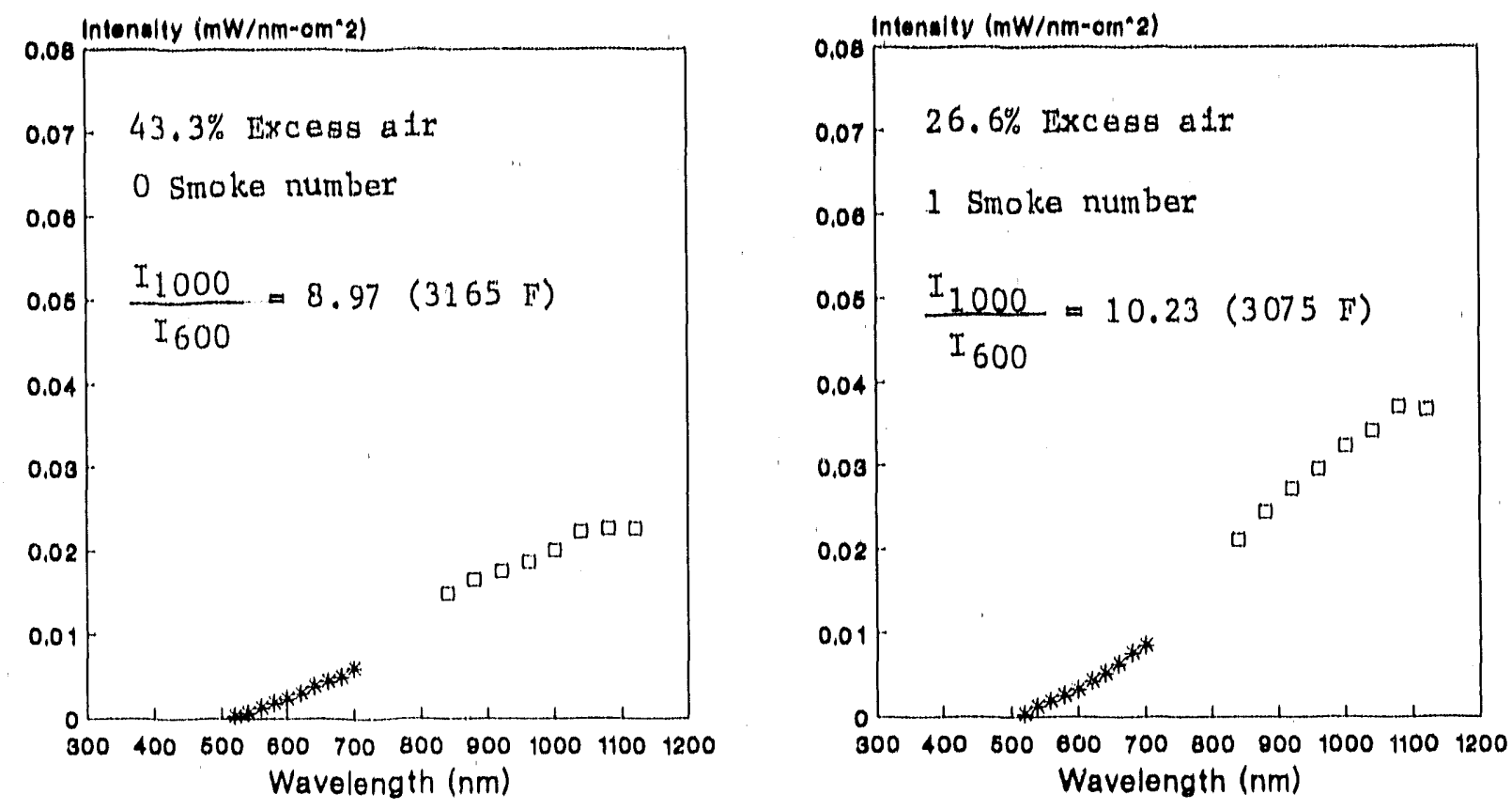

* = 12001 lnes/mm grat.tng

D = 6001 lnes/min grating
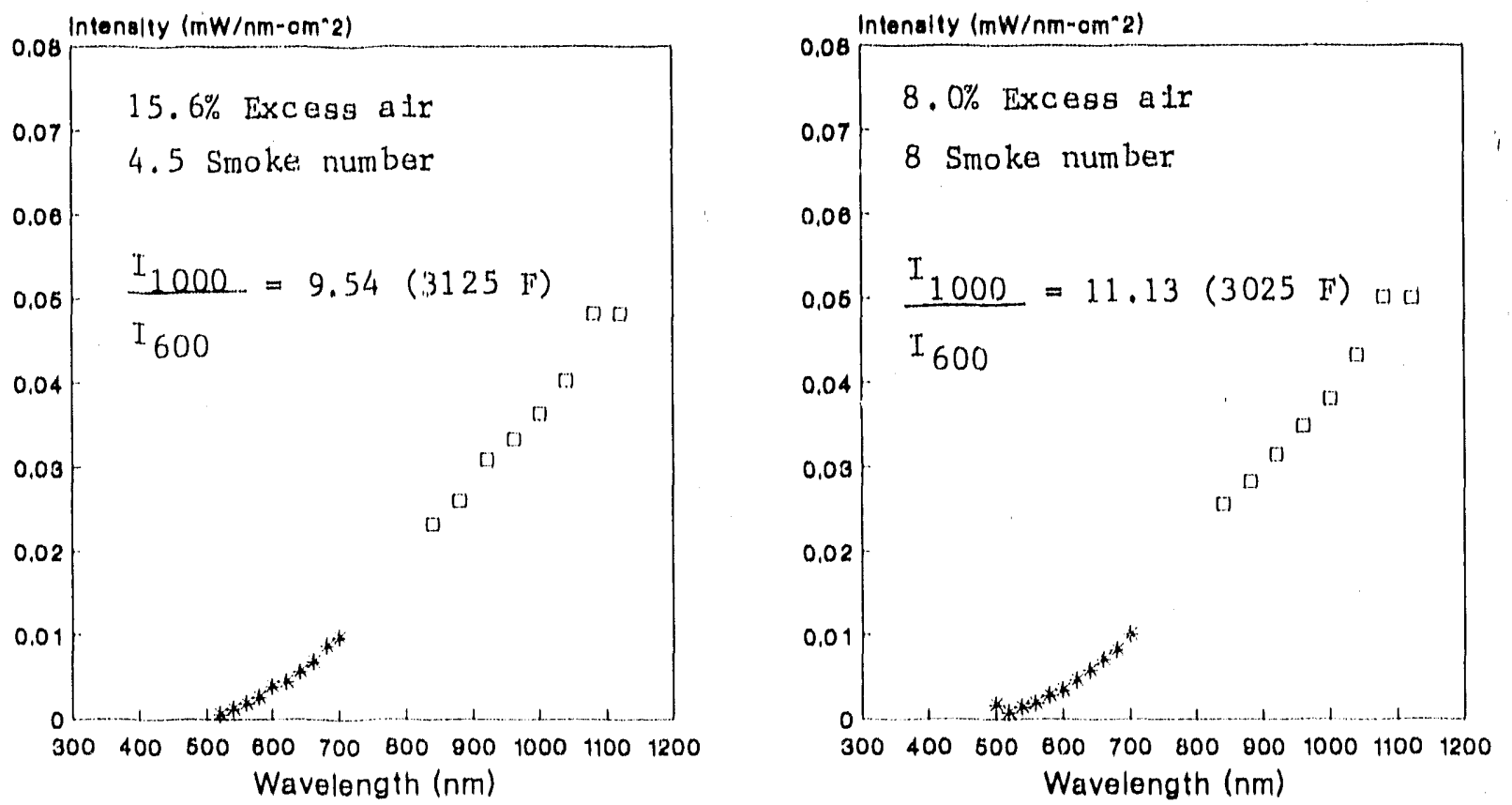

F1gure 52. Optical Endsaion Spectra Without a Combuation Chamber. Note - Temperatures in parenthesio Indicate "apparent" flame temperatures using black body assumption and ratio of tntensteles at 1000 and 600 nin. 


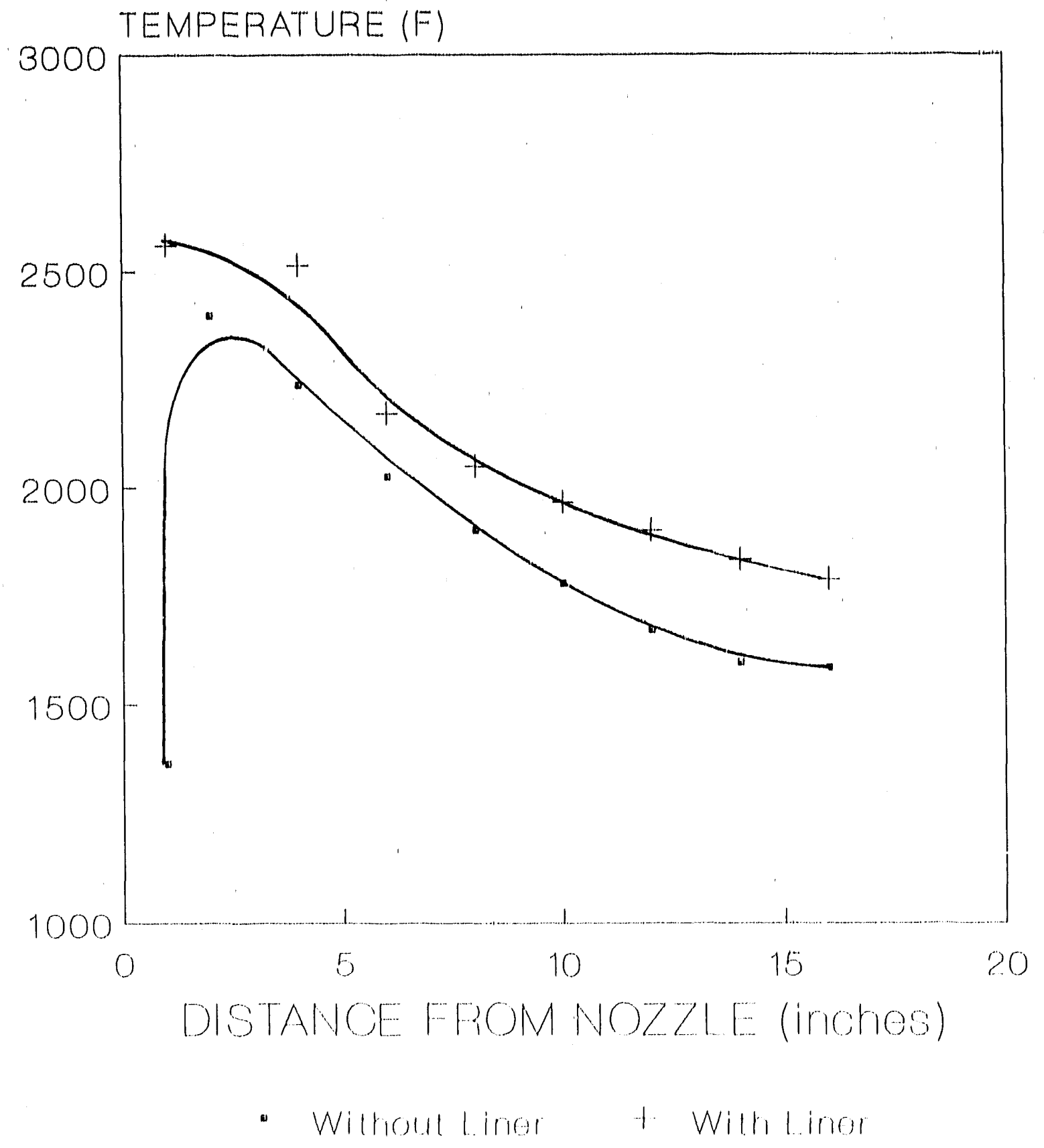

Figure 53. Measured Flame T'emperatures Along Combustion Chamber Axis. 
Interesting to note the sharp reduction in temperature near the nozzle in the cold wall case. This 18 likely due to an tncreased flame standoff diatance.

Durling this profect an effort was made to measure centerilne temperature proflies with the suction pyrometer as a function of excess atr. Generaliy, over the range of excess air examined ( 25 to $60 \%$ ) no consiatent trend was found. Measured temperatures were found to be Independent of excess alr to within about $50^{\circ} \mathrm{F}$.

The use of a very simple optical sensor like the cad cell or Pbse photoconductor to indicate flame quality lo obviously very attractive fran a cost perspective. As in the case of the narrow wavelength measurements discussed earlier, however, the possible effects of changes in firling rate and spray pattern on this slynal have to be established. For this purpose a serles of ineasuremente were compared for elght selected nozile cases. These includes

$$
\begin{aligned}
& \text { A. } 0.75 \mathrm{gph}, 70^{\circ} \text { solld } \\
& \text { B. } 0.85 \mathrm{gph}, 70^{\circ} \text { hollow } \\
& \text { C. } 1.0 \mathrm{gph}, 70^{\circ} \text { hollow } \\
& \text { D. } 0.5 \mathrm{gph}, 70^{\circ} \text { hollow } \\
& \text { B. } 0.65 \mathrm{gph}, 80^{\circ} \text { hollow } \\
& \text { F. } 0.65 \mathrm{gph}, 80^{\circ} \text { solld } \\
& \text { G. } 0.65 \mathrm{gph}, 60^{\circ} \text { hollow } \\
& \text { H. } 0.65 \mathrm{gph}, 60^{\circ} \text { solld }
\end{aligned}
$$

Figure 54 shows the cad cell resiatance/smoke number relationships for all elght nozzles. Flgure 55 shows the same relationships for the $\mathrm{PbSe}$ photoconductor. All of these data were taken using the retention head burner flring into the hot water boller. Note that for these teats the cad cell was mounted in 1 ts conventional location (below the transformer) but the PbSe cell was mounted further forward, close to the retention head.

In an Ideal case all of the restatance/smoke number polnts might: fall on a single curve and the photoconductors would be univeraal indlcators of flame quality. This certalniy did not occur, although most of the data do fall within a reasonably narrow band. A very notable exception to this ta the case of the very low firlng rate ( $0.5 \mathrm{gph}$ nozzle D) and the cad cell (FLg. 54). Because of the low firlng rate the intensity reaching the cad cell 10 signiflcantly lower than for the other nozzles. Wlth the PbSe cell, which views the flame essentlaliy from the centerline, the 10 s in intenslty (Increase in resiatance) with the low firing rate lo not as pronounced.

If ether photoconductor were to be used as a "untversal" flame quelity sensor, then the burner excess a dr would be adjusted to glve a fixed value of restatance In steady state. T'o lliugtrate the consequences of doing this with these efght nozzles, reslatance values of 190 ohms and 55 kohing were chosen for the cad cell and PbSe photoconductors, respectively. Resulting getpolntes are shown on the smoke number/excess atr curves for the burner fired with each of the elght nozzles in rigure 56 (over two pages). The case of the cad cell with the $0.5 \mathrm{gph}$ nozzle 18 not shown as this control approach would almply not work at that firlng rate. For all other cases ither sensor would cause the burner to be set falrly close to the 1deal t".ce smoke point. Of the two sensors the PbSe ..noor gives a better setpolr.t. This may be simply a regult. of the placement of that sensor rather than the wavelength response range. 


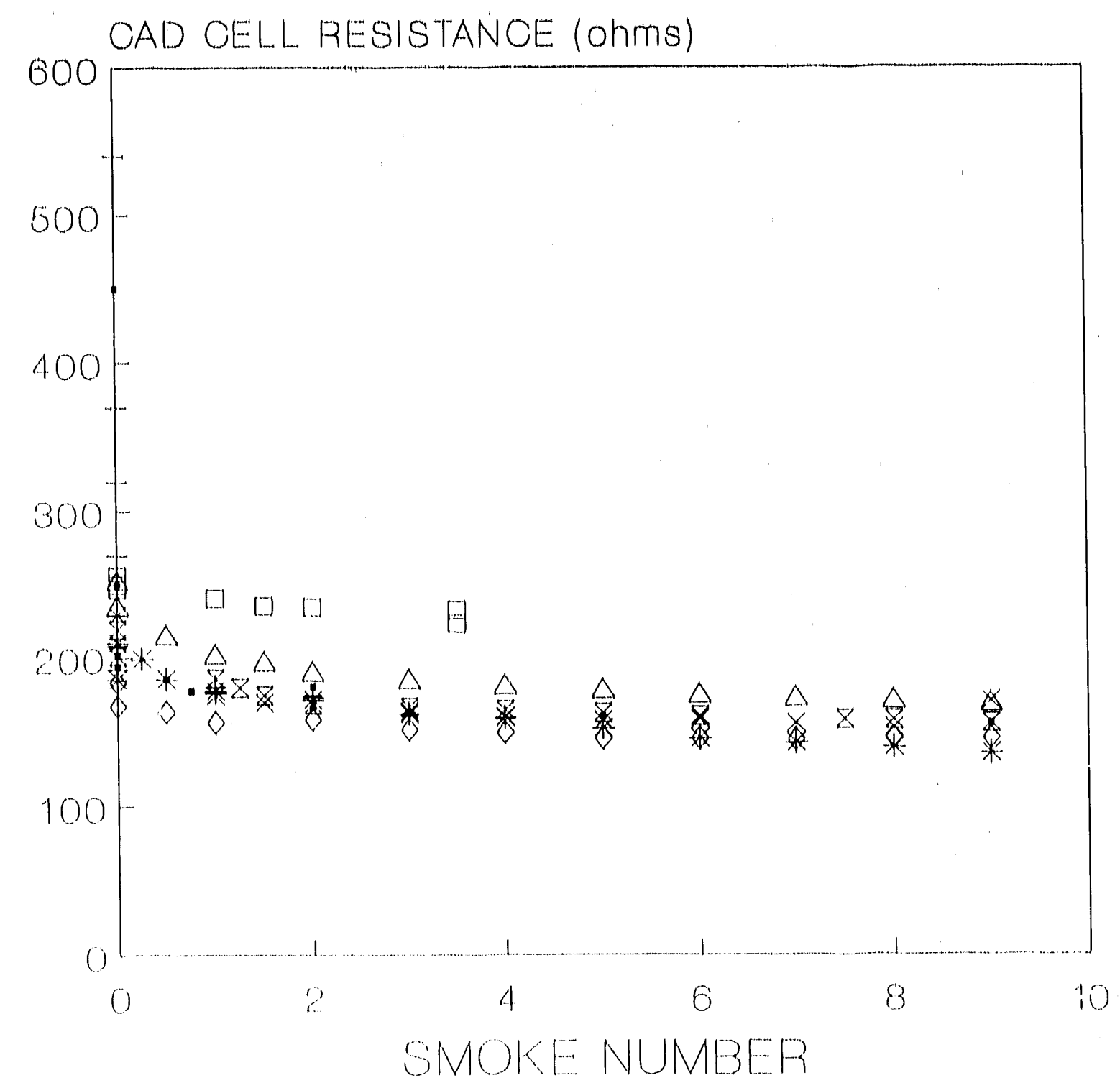

Nozzle:

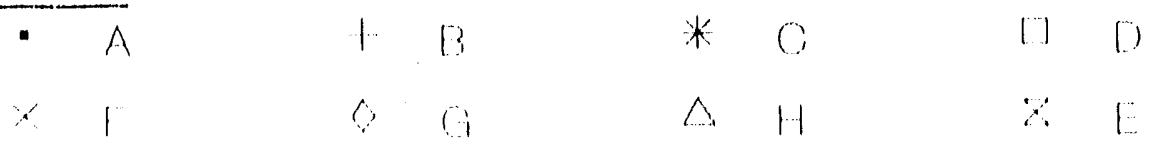

Figure 54. Reststance of cadmlum sulfide photoconductor as a function of steady atate smoke number for elght nozzles - retention head burner. 


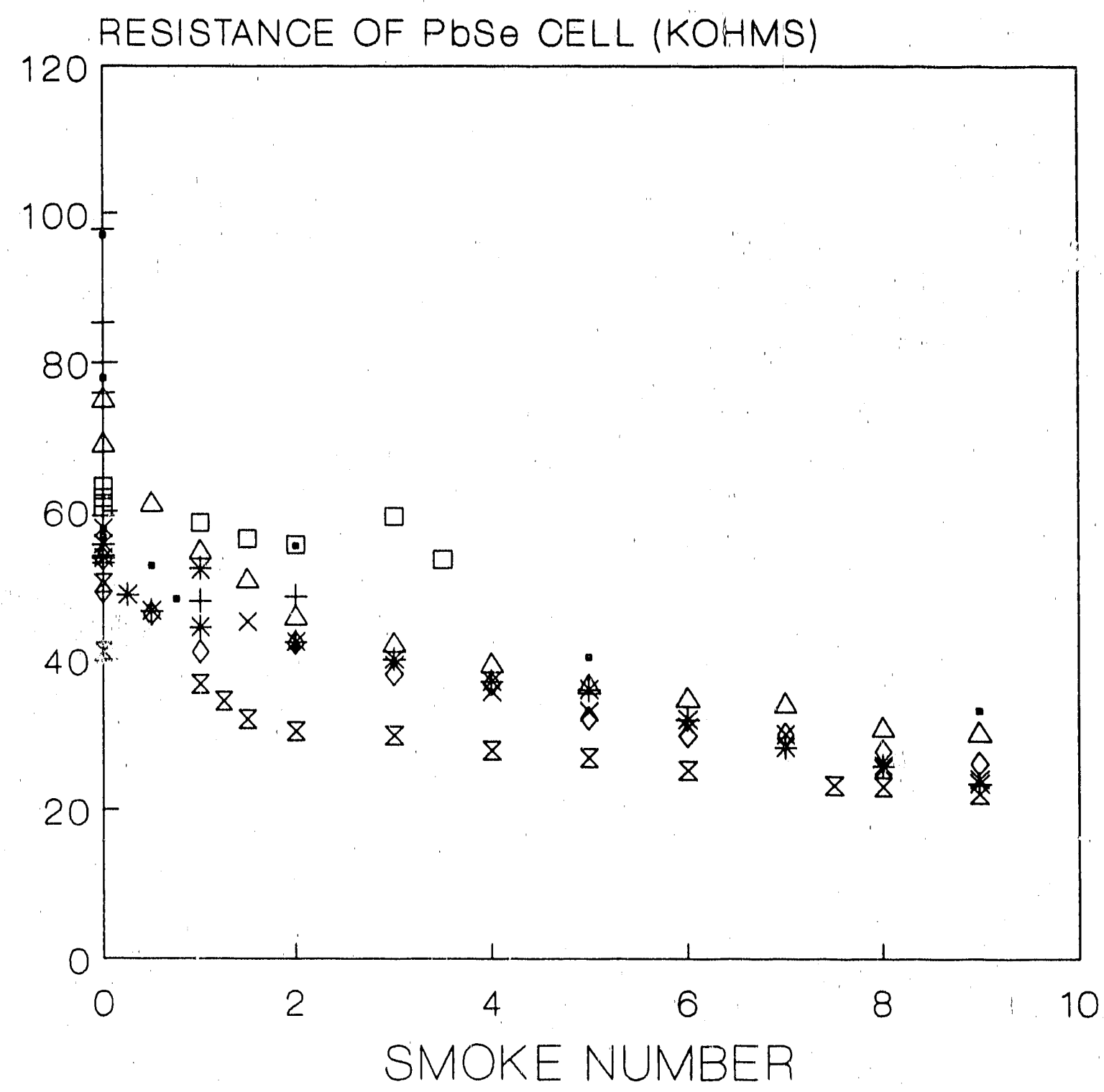

Nozzle:

\begin{tabular}{lllllll}
\hline$A$ & + & $B$ & $*$ & $C$ & $\square$ & $D$ \\
$\times$ & $F$ & $\triangle$ & $\triangle$ & $H$ & $\nabla$ & $E$
\end{tabular}

Figure 55. Resistance of lead selenide photoconductor as a function of steady state smoke number for eight nozzles - retention head burner. 

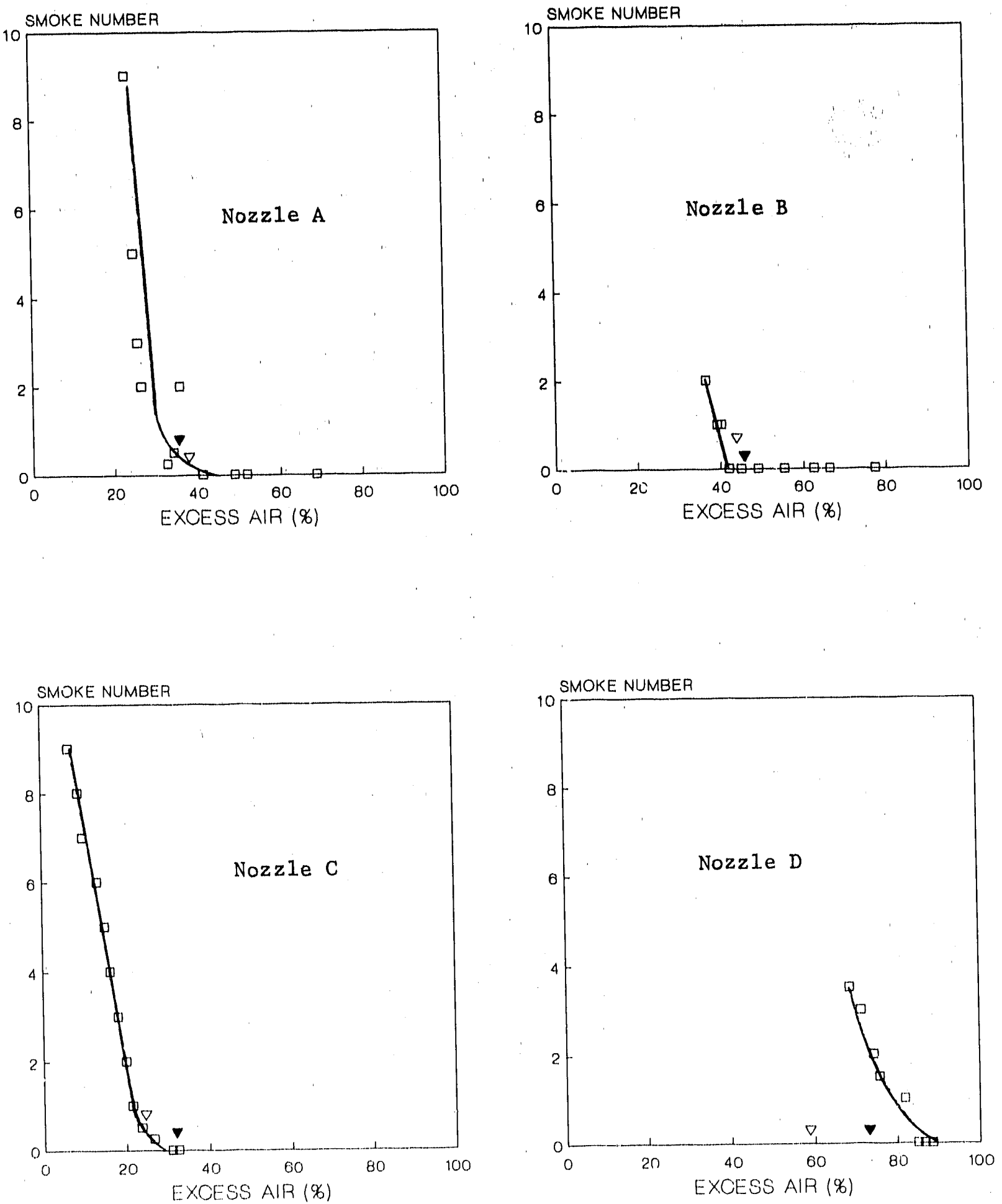

Figure 56. Excess atr setpoints based on resistance of cadmium sulfide $(\nabla)$ and lead selenide $(\nabla)$ photoconductors retention head burner with eight nozzles. 

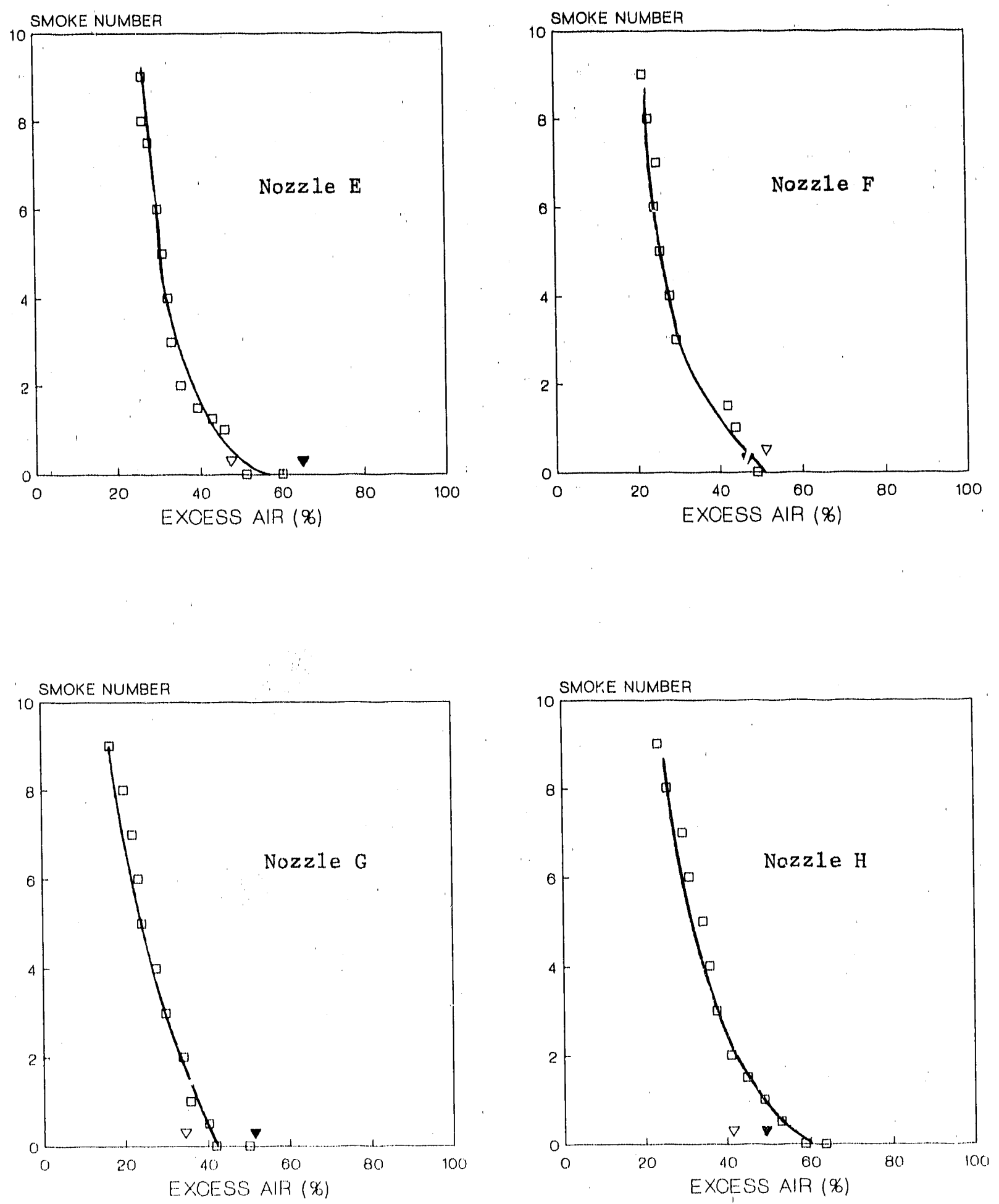

Figure 56. Excess air setpoints based or resistance of cadmium (cont.) sulfide $(\nabla)$ and lead selenide $(\nabla)$ photoconductors retention head burner with elght nozzles. 
To evaluatie the effect of location of the cad cell some additional tests were performed with the cell moved closer to the retention head, near the PbSe ce11. In the first test set at this location the cad cell was set to view the flame directly, through the center opening of the retention head with a very narrow view angle. At this location the results were found to be strongly affected by nozzle spray angle and not generally useful. The sensor was then moved forward to view the flame through a much wider angle, again through the center hole in the retention head. Results at this location in the form of cad cell resistance as a function of smoke number for the eight nozzle sets are shown in Figure 57. In Figure 58 (over two pages) the setpoints which would result from two different choices of resistance of the cad cell at the forward location are lllustrated for the eight nozzles. In all cases an acceptable excess air setting is realized:

\subsubsection{Conventional Retention Head Burner, Vlewed from the Back End}

Measurements of the flame optical emissions were made from a viewpoint at the back end of the boller illustrated in Figure 4. A fiber optic cable was used to collect the light from the access port and transmit it to the monochroneter. The port is located on the centerline of the combustion chamber and the fiber optic cable tip is cooled by alr, drawn in by chamber draft.

In Figure 59 optical intensity at $550 \mathrm{~nm}$ (center of the visible) is plotted as a function of smoke number for three different firing rates. This data indicates some increase in intensity with firing rate. In addition and particularly for the 0.6 and 0.7 gallon per hour nozzles a peak in the emission intensity near a smoke number of 0 to 1 and a decrease in intensity as the smoke number increases over the range $2-6$ is observed. This result is markedly different from previous results obtained with the optical sensors located within the burner housing, which indicated much better agreement between the intensity/smoke curves for different firing rates. In addition, intensity measured from within the burner housing showed a continuous increase with snoke number over the range $0-10$.

In Figure 60 the ratio of the intensities at 600 and $400 \mathrm{~nm}$ is shown as a function of the smoke number for the three firing rates. As discussed in the previous section, this ratio is a rough measure of flane "color" or effective flame temperature. In this case the relationship is very similar for all three nozzles, which suggests that flame color measured from the back end could be a very useful indicator of flame quality. Measurements made from a viewpoint within the burner housing (previous report section) did not indicate a consistent relationship between "color" and flame quality with different nozzles.

\subsubsection{Air Atomized Burner}

Optical emission measurements were made with the air atomizing burner (Airtrontc/Babington) firing into the boller illustrated in Figure 4. Due to the unique geometry of this burner, measurement of optical emissions from a viewpoint within the burner housing are very difficult. For this reason, measurements were made only from a backend viewpoint as in section 4.5.2. 


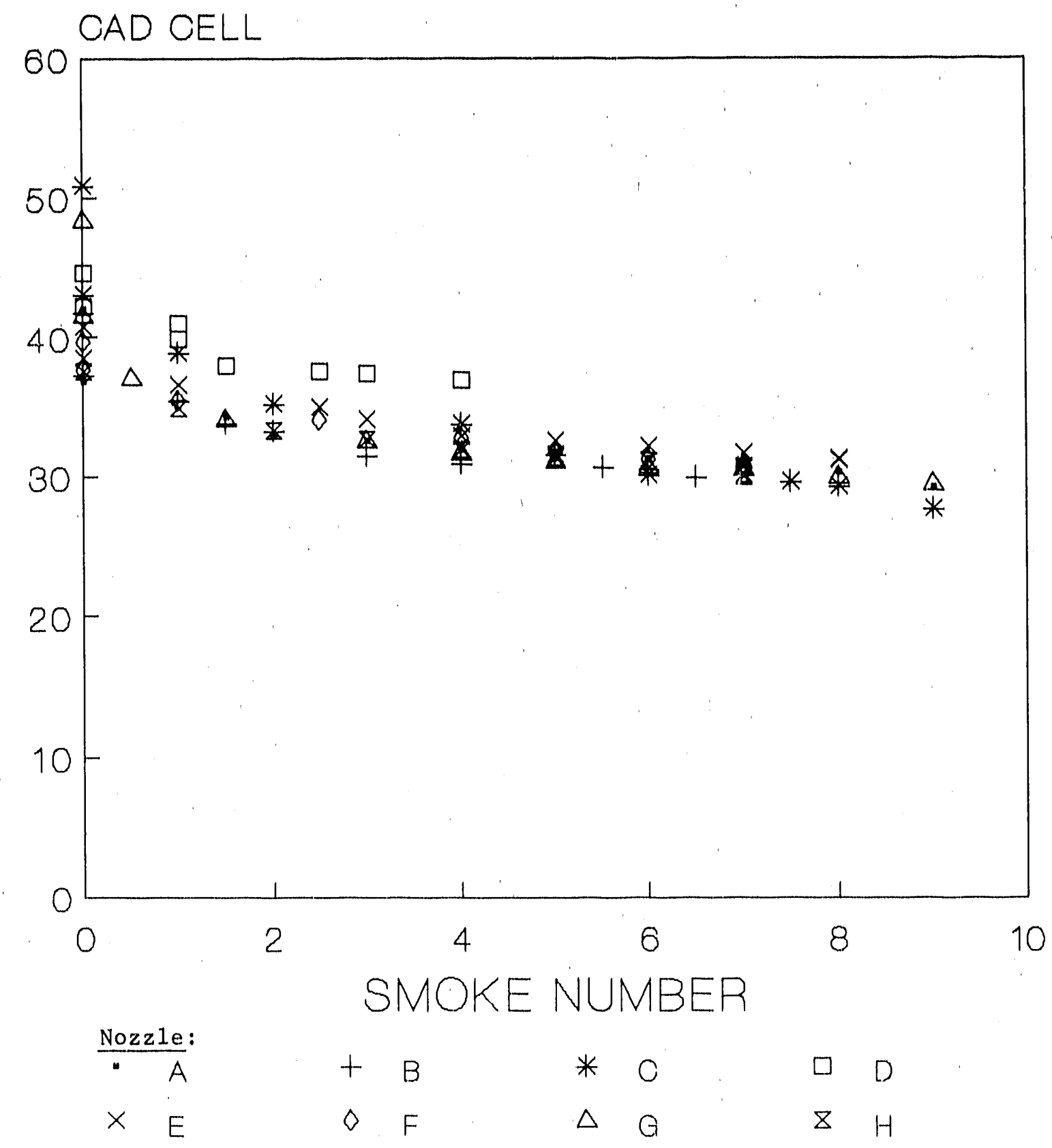

Figure 57. Resistance of cadmium sulfide photoconductor in forward position as a function of steady state smoke number for eight nozzles .. retention head burner. 

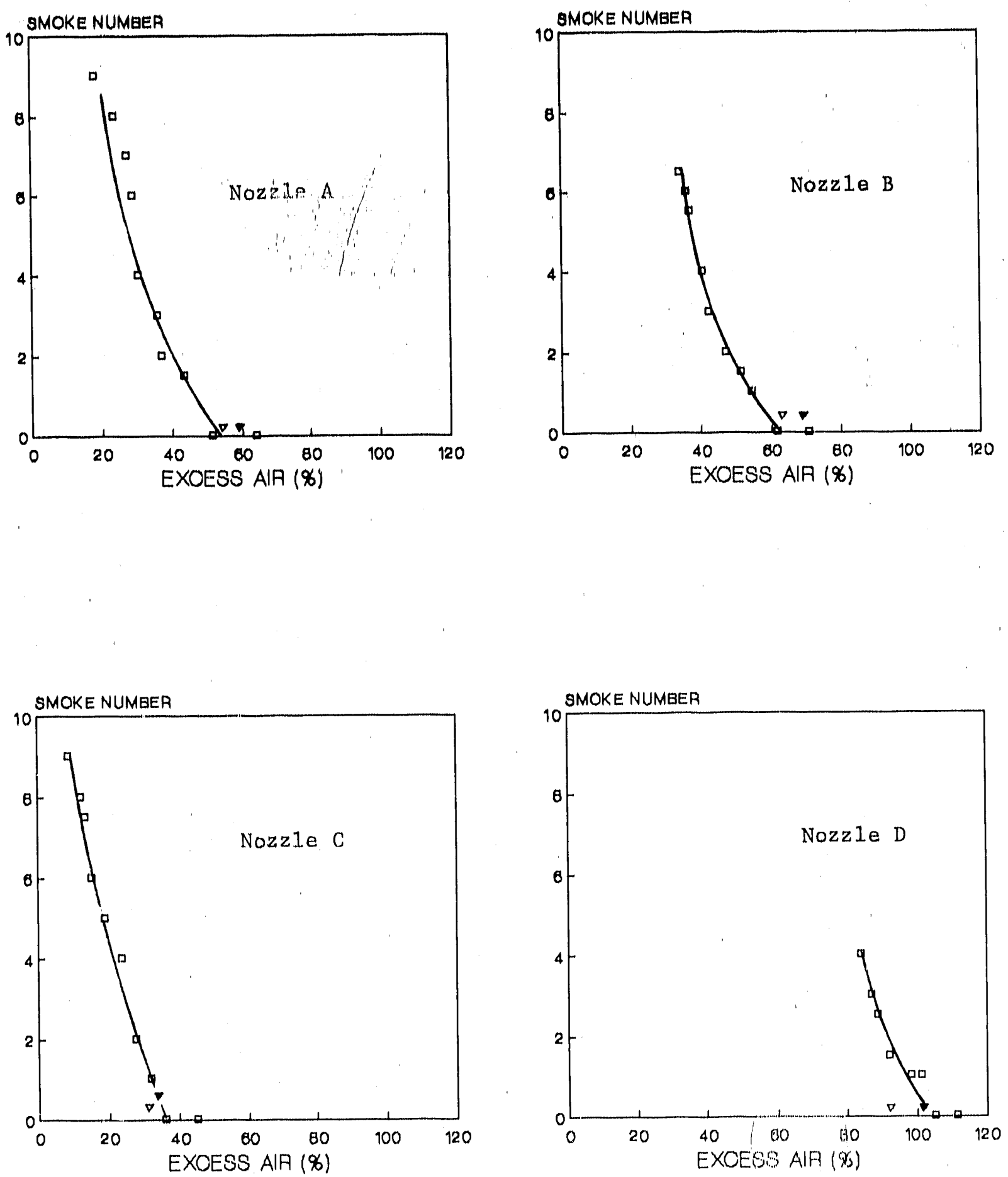

Figure 58. Excess air setpoints based on the resistance of the cadmium sulfide photoconductor at the forward location $(\nabla-38$ ohms; $\nabla-41$ ohms). 

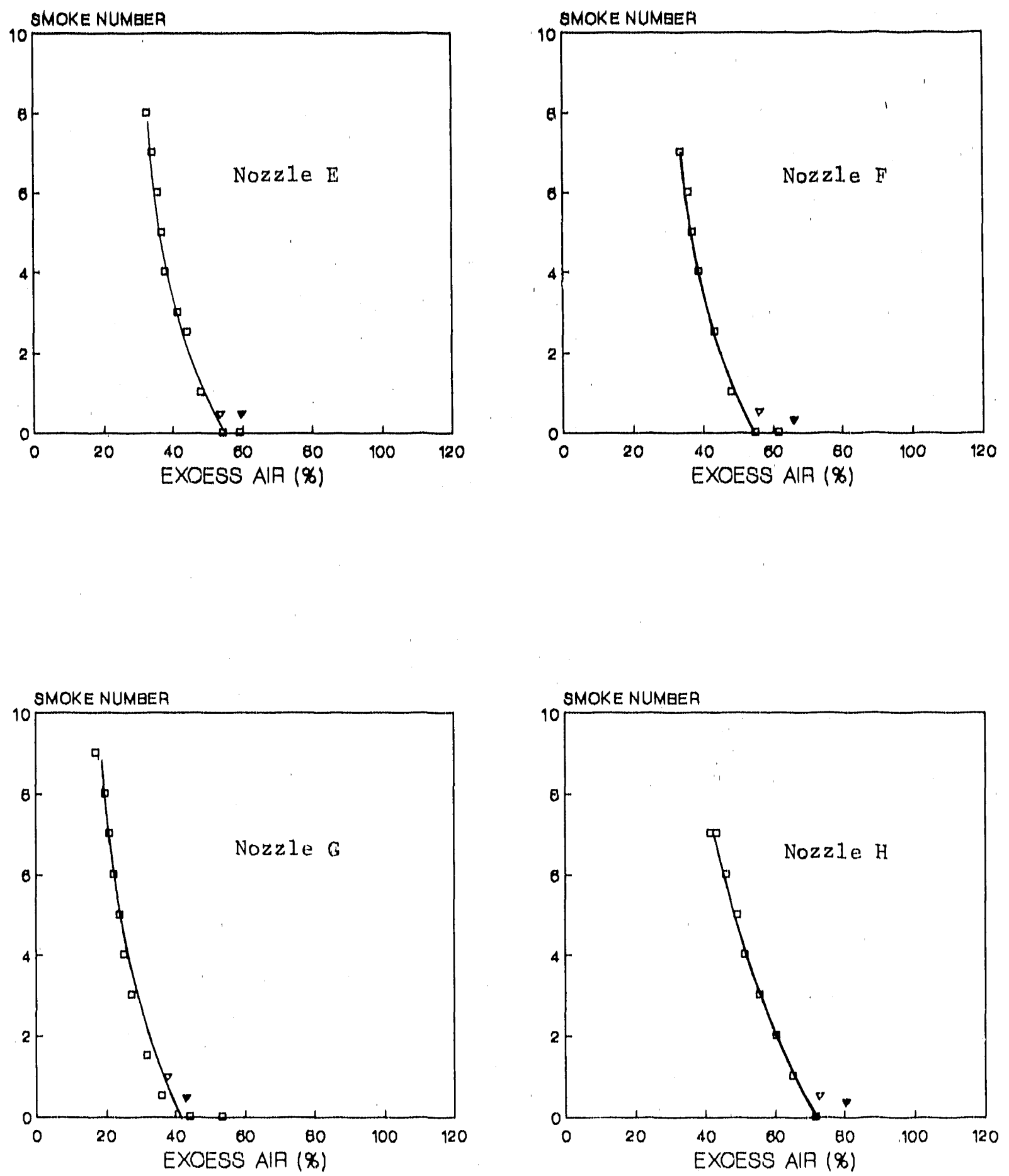

F1gure 58. Excess air setpolnts based on the resistance of the (cont.) cadmium sulfide photoconductor at the forward location $(\nabla-38$ ohms; $\nabla-41$ ohms $)$. 


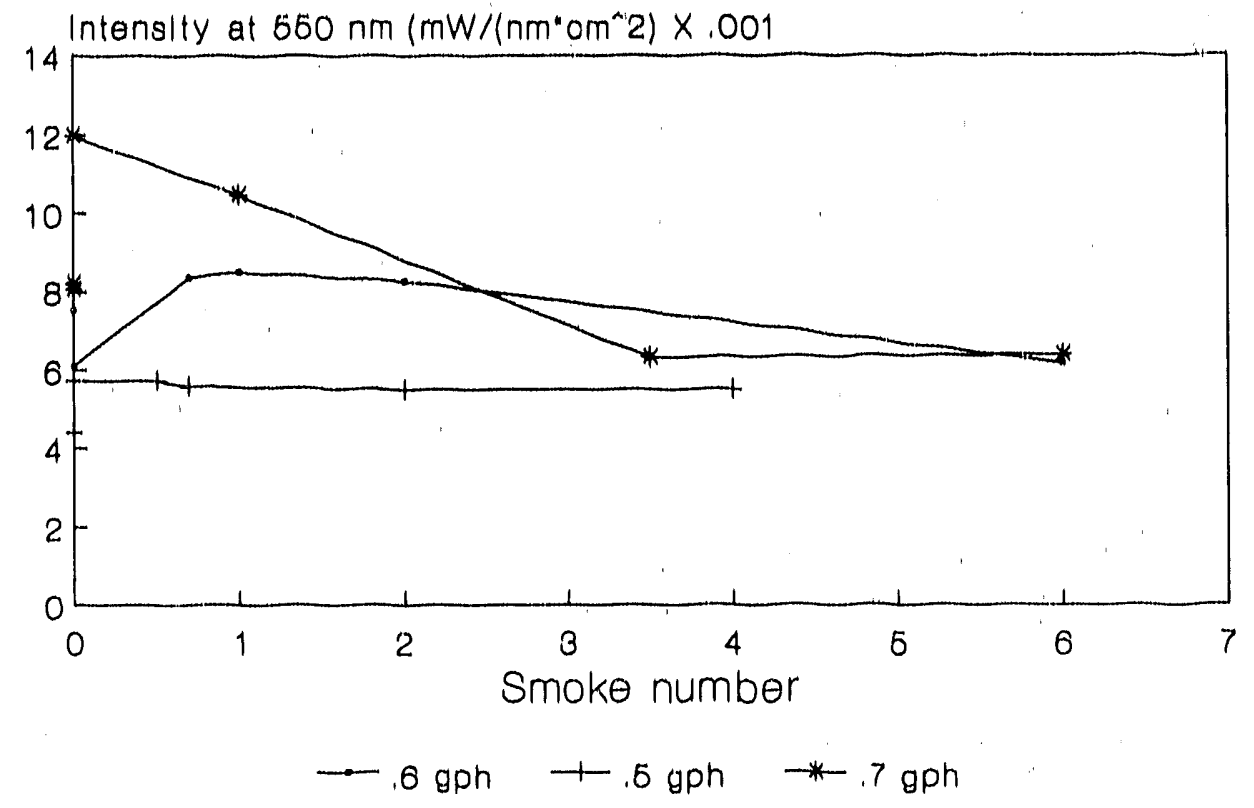

Figure 59. Viewpoint at the end of the combustion chamber. Intensity at $550 \mathrm{~nm}$, three nozzles.

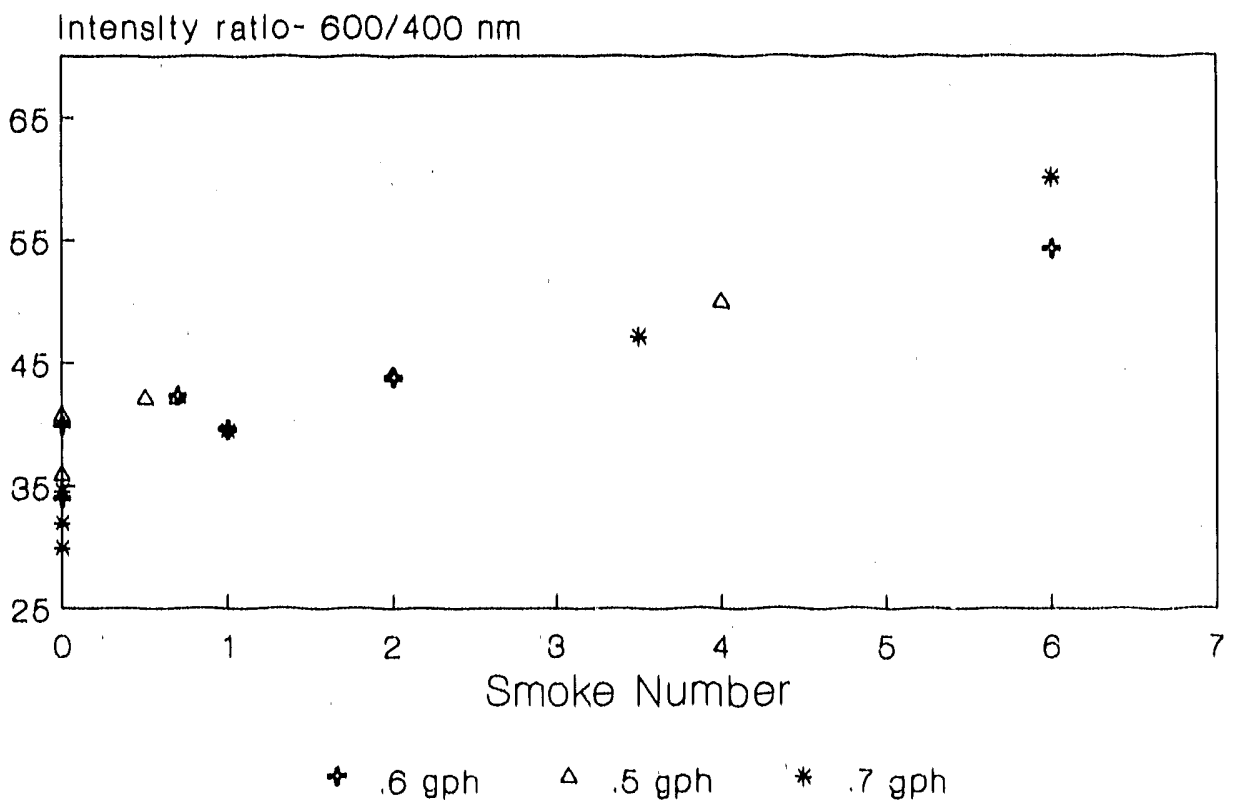

Figure 60. Viewpoint at the end of the combustion chamber. Intensity ratio vo. smoke number, three nozzles. 
Teats were performed at a firlng rate of 0.5 gallons per hour and Figure 61 showg the smoke/excess atr relationship at this condition. Figure 62 shows the neasured intensity at 550 nim (center of visible) as a function of excess alr. The trend shown by this data do very simflar to that with conventlonal pressure atomized burners with a viewpolnt within the burner houglng. Comparad with data taken with pregsure atomlzed burners with a backend viewpolnt, the intensities with the alr atomized burners are about half. In Figure 63 the ratio of intensitles at 600 and $400 \mathrm{~nm}$ is shown as a function of excess a1r. As with conventional pressure atomlzed burners (viewpolnt in burner housing) the trend 1s toward lower ratios of lntenglties at 600 to $400 \mathrm{~nm}$ (higher flame temp) with increasing excess air. With the alr atomized burner, however, the apparent flame temperatures are signiflcantly higher (Lower $600 / 400$ Intensity ratio) across the excess alr range.

\subsubsection{Transient Optical Emissions}

Results which have been reported In prevlous sectlons include data taken with burners operating in ateady state. While this is important, residential oll burners always operate cyclically. A typlcal boller, for example, may realize 6 to 8 thousand firlng cycles per year and the average on-times range from 5-10 minutes. It to limportant, then, to consider the effect of these translents on optical indicators of flame quality.

For this purpose the warm-up pertod is the time required to heat the combustion chamber refractory insert to 1ts steady state temperature. During the warm-up pertod flame temperature is lower than in steady state because of the cooler chamber walls. This reduced flame temperature would reduce the intensity of the optical emissions and move the apparent flame color to longer wavelengths. During the warm-up period the reduced flame temperature leads to increased soot emissions. Th1s would act opposite to the ceduced flame temperature and increase the total optical emission intensity. Increasing soot would not, by 1 tself, affect flame color very strongly during the warm-up period.

Transient measurements were made using the three broad band sensors installed in the retention head burner mounted in the dry base steel boller as discussed in section 4.5.1. Results are shown 1n Flgure 64. During the first few minutes of operation the smoke number 1s quite high. In steady state such high swoke levels would give increased levels of emissions throughout the spectrum. Apparently, during startup the cold walls of the combustion chamber are reducing flame temperature and optical emission intensities. The effect of the cold walls dominates over the effect of increased emisalvity from the flame due to the increased soot. During the warm-up period the cad cell approaches its steady state value (on a relative basis) sooner than the IR or thermocouple sensor. The cad cell requires about 10 minutes of firing to approach 1ts steady state value. Durlng the time period from 1 to 10 mfnutes, however, the change ia excess air assoclated with the changing reatstance 18 only about $10 \%$ (roughly 45 to $34 \%$ excess air in this spectflc case).

The duration of the warm-up transient 1 s dependent upon the combustion chamber arrangement. To 111ugtrate thls, Figure 65 shows the trend in cad 


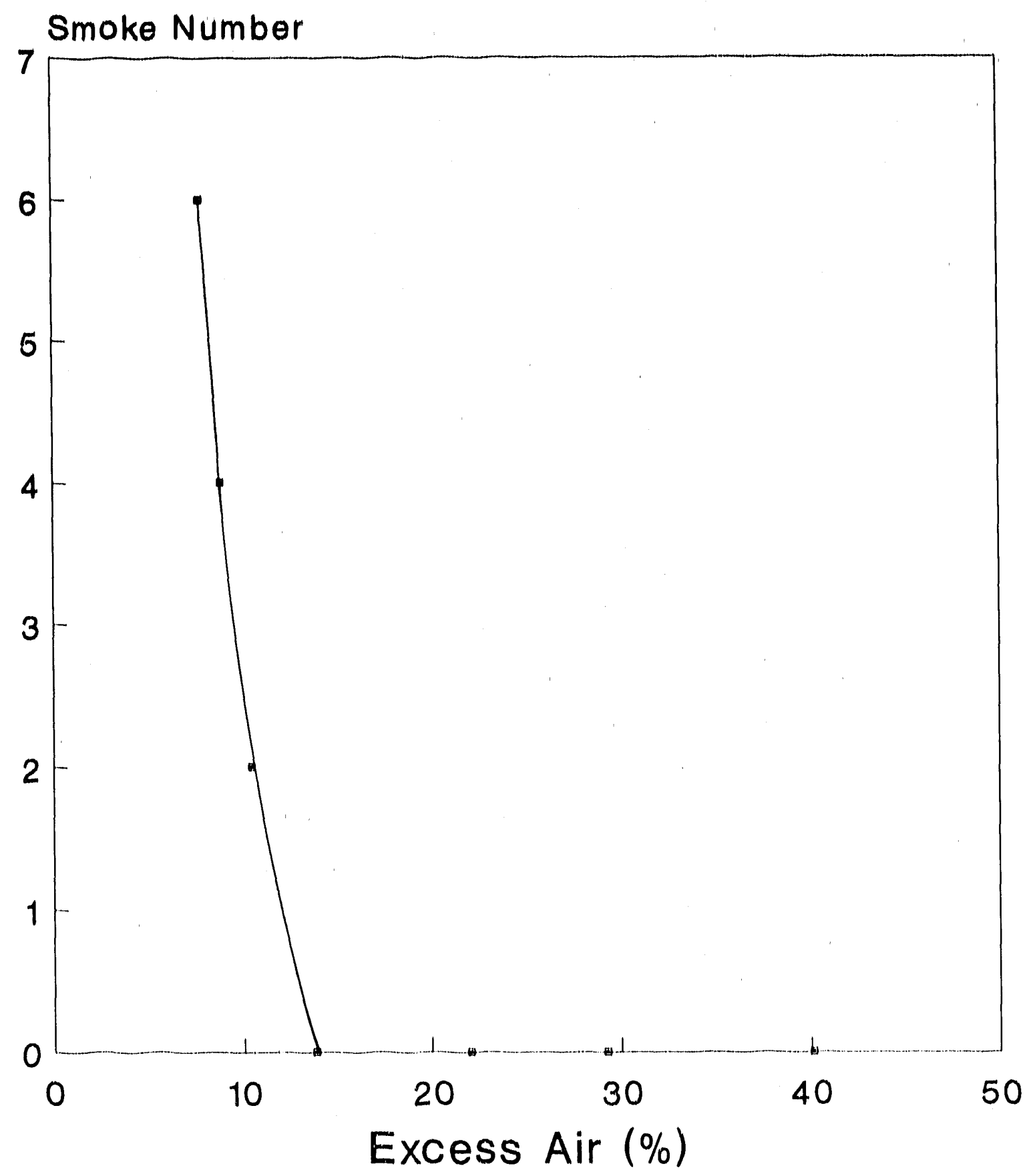

Figure 61. Air Atomized Burner. Smoke Number/Excess Alr Relation. 


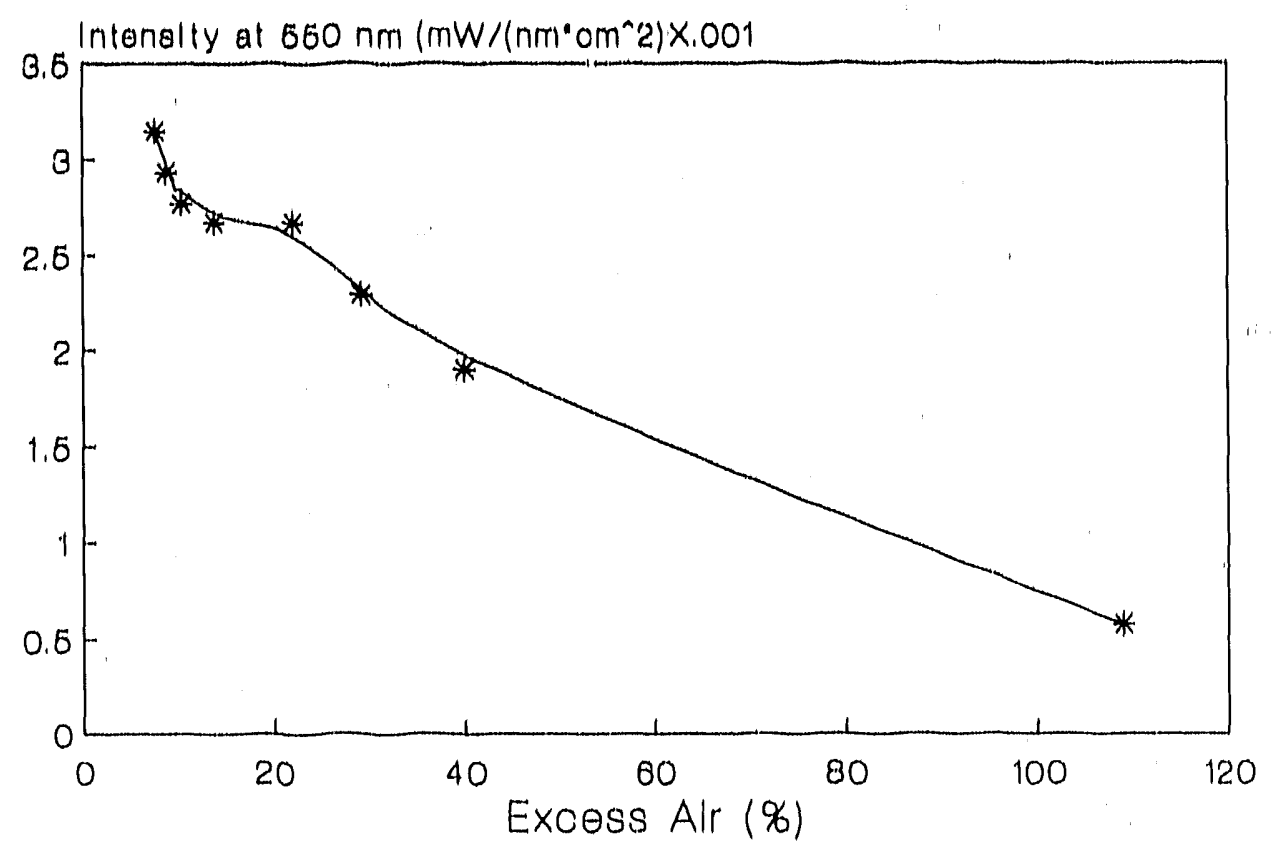

Flgure 62. Alr atomized burner. Intensity at $550 \mathrm{~nm} \mathrm{vs.}$ excess alr. Vlewpoint at end of the combustion chamber.

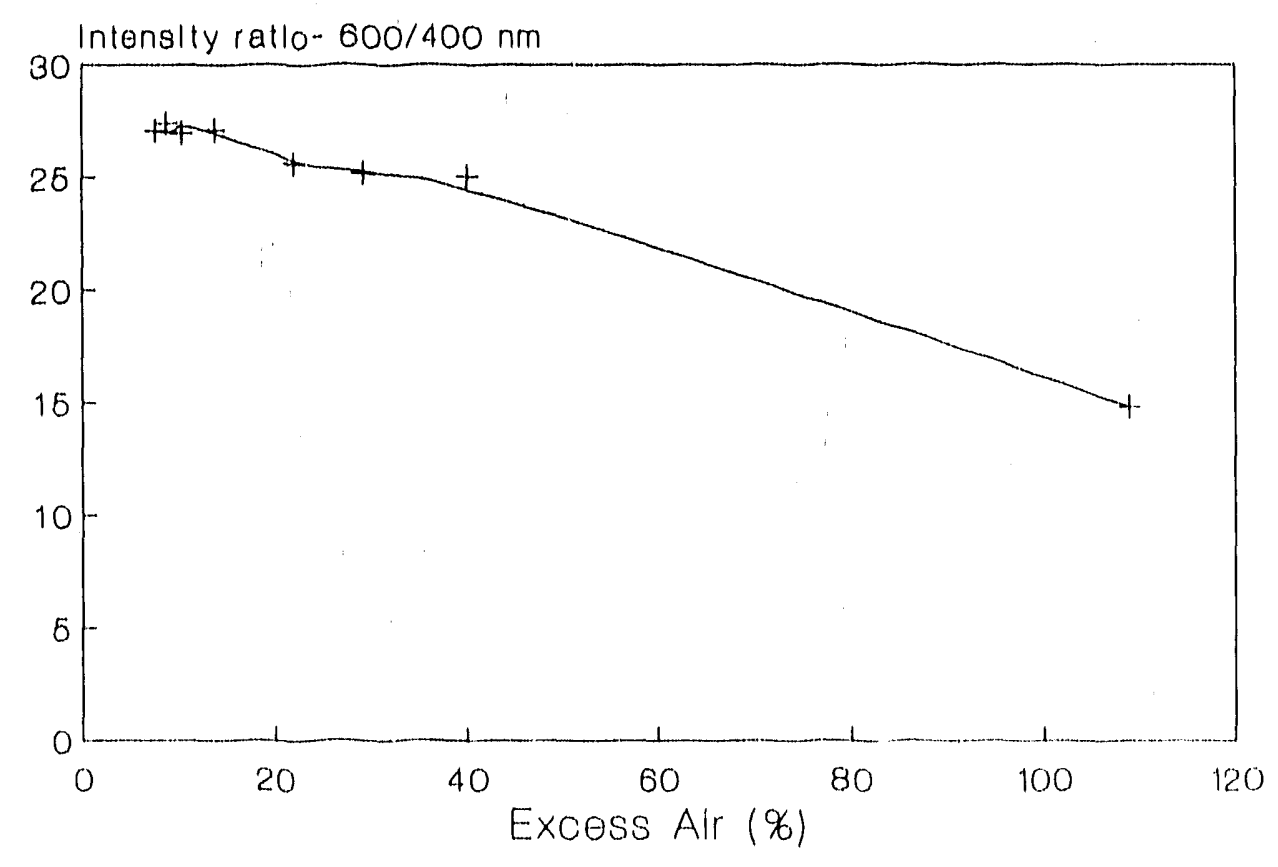

Figure 63. Alr atomized burner. Intensity ratto vs, excess atr. Vlewpoint at end of the combuation chamber. 

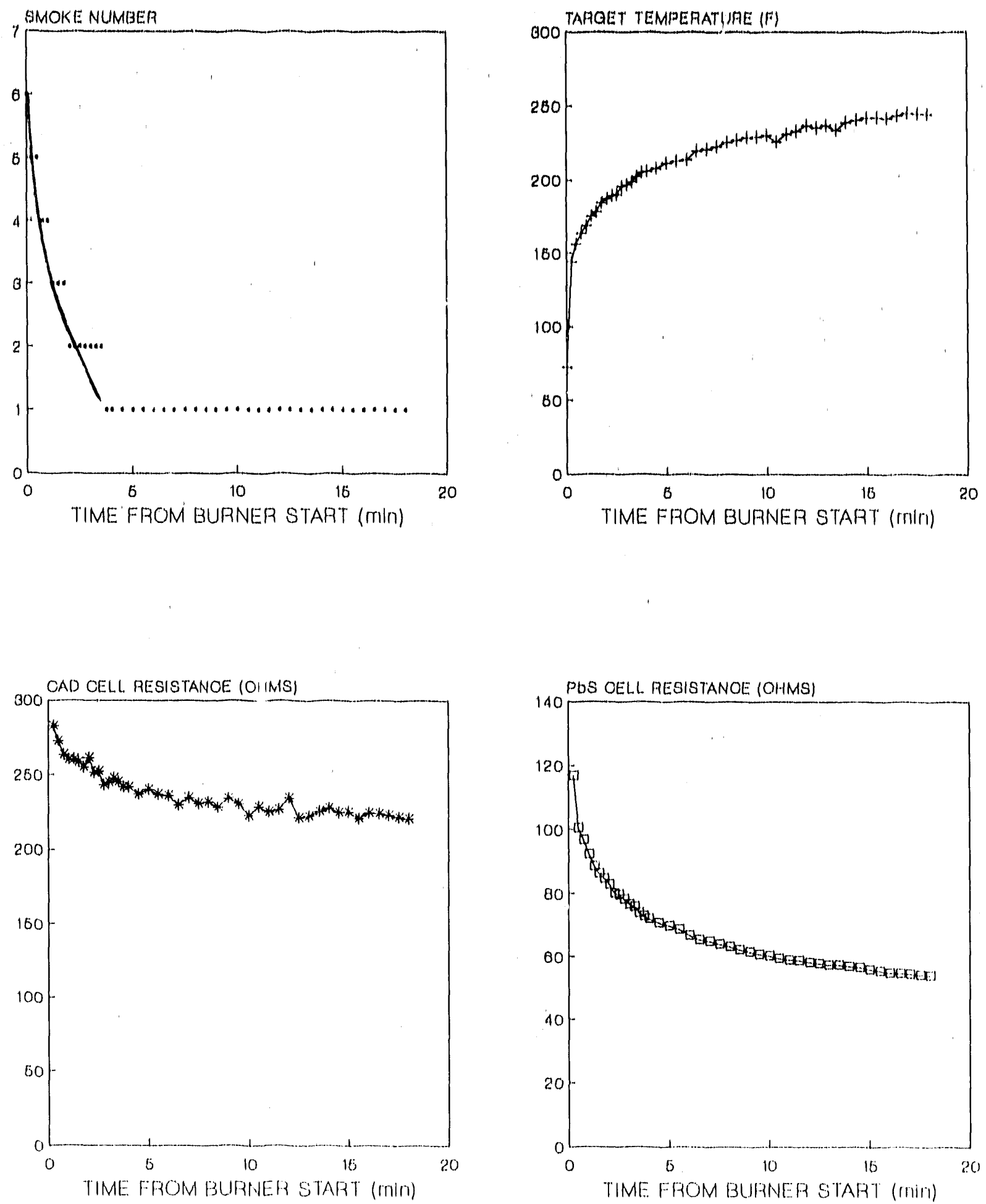
Flgure 64. Smoke number and response of broadband sensors over
a firlng cycle - retention head burner. 


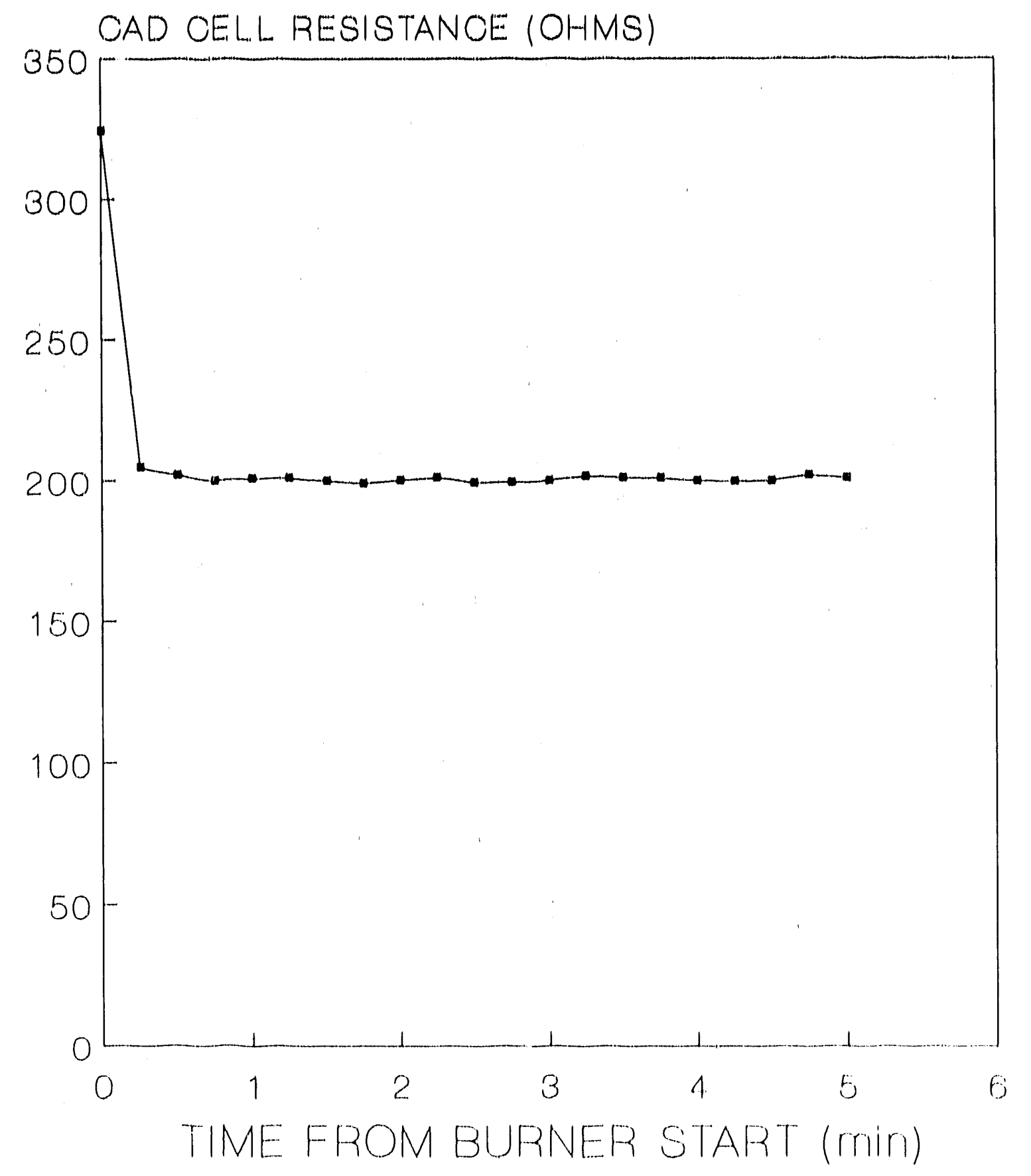

Figure 65. Cad cell resistance over a flring cycle-wet base boller. 
coll ragiatance after atartup for a retention had burner mounted in a watbase cast Iron bolier. Thla boller has a "bucket" type combustion chamber with a falrly thin wall (" $\left.3 / 8^{\prime \prime}\right)$. Some additional data of this type was taken with two other wet base bolders with and without combustion chambers. Generaliy, the warmm time to related to the combuation chamber refractory mass. Wat base bollers with no combustion chambar have warm-up times on the order of a few seconds. 


\section{CONTROL SYSTEM OPTIONS}

Results presented in the previous section suggest a number of approaches for control systems. The practical aspects of the implementation of these are discussed in this section. A critical factor for any control system which is discussed in this section is the availability of suitable sensor system components and the cost of these components. As discussed in Section 1.1 two basic control modes are considered, 1) service required signals, and 2) steady state excess air trim. Ail of the cost estimates discussed in this section are "O.E.M." or wholesale costs. In most cases these estimates have been obtained from manufacturers. In some cases estimates of O.E.M. costs are based on retail costs.

\subsection{Optical Sensors}

Table 2 lists the common types of optical sensors which could be considered for use in control applications. Photoconductors are made from semiconductor materials and experience a bulk decrease in resistance, with increasing light intensity. A photodiode consists of a PN junction arranged so that light can strike the junction area. The response characteristics of a photodiode depend upon the way in which the diode is biased. Connected to a high impedance sensor circult (no diode current), the dlode operates as a photovoltaic device with output voltage increasing with the logarithm of light intensity. If connected to a very low input impedance sensor circuit, the output current has a linear relationship with light intensity. Relative to photoconductors, photodiodes are less sensitive because they respond only at the junction while the photodiode responds throughout the material. The photodiode, however, has much faster response times which is important in some applications. Junction type detectors can be configured in different ways to amplify the output signal. Examples of this include the phototransistor and photodarlington transistor.

For measuring intensity over the entire visible range Cadmium Sulfide (CdS) photoconductors are the sensors of choice. These sensors, which are commonly used for flame proving in oil burners, are inexpensive $(\$ 1.00$ to $\$ 2.00$ each). Silicon photodiodes, which respond over a similar wavelength range, are similar in cost but not as sensitive.

Figure 66 illustrates the relationship between resistance and light intensity for CdS photoresistors. Over a small intensity range this curve can be approxinated by a straight line and relationship between resistance and intensity expressed as:

$$
\mathrm{R} \propto \mathrm{I}^{-\mathrm{n}}
$$

The value of $\mathrm{n}$ approaches 1 at low levels of light intensity and decreases toward zero at high levels. A high value of $n$ means high sensitivity. With nost of the measurement made during this project the intensity was in a range which produced an $n$ value of about 0.5. In an optical control system sensitivity could be improved by reducing the intensity of light at the cell. The best method of achieving this is with the addition of a filter between the 


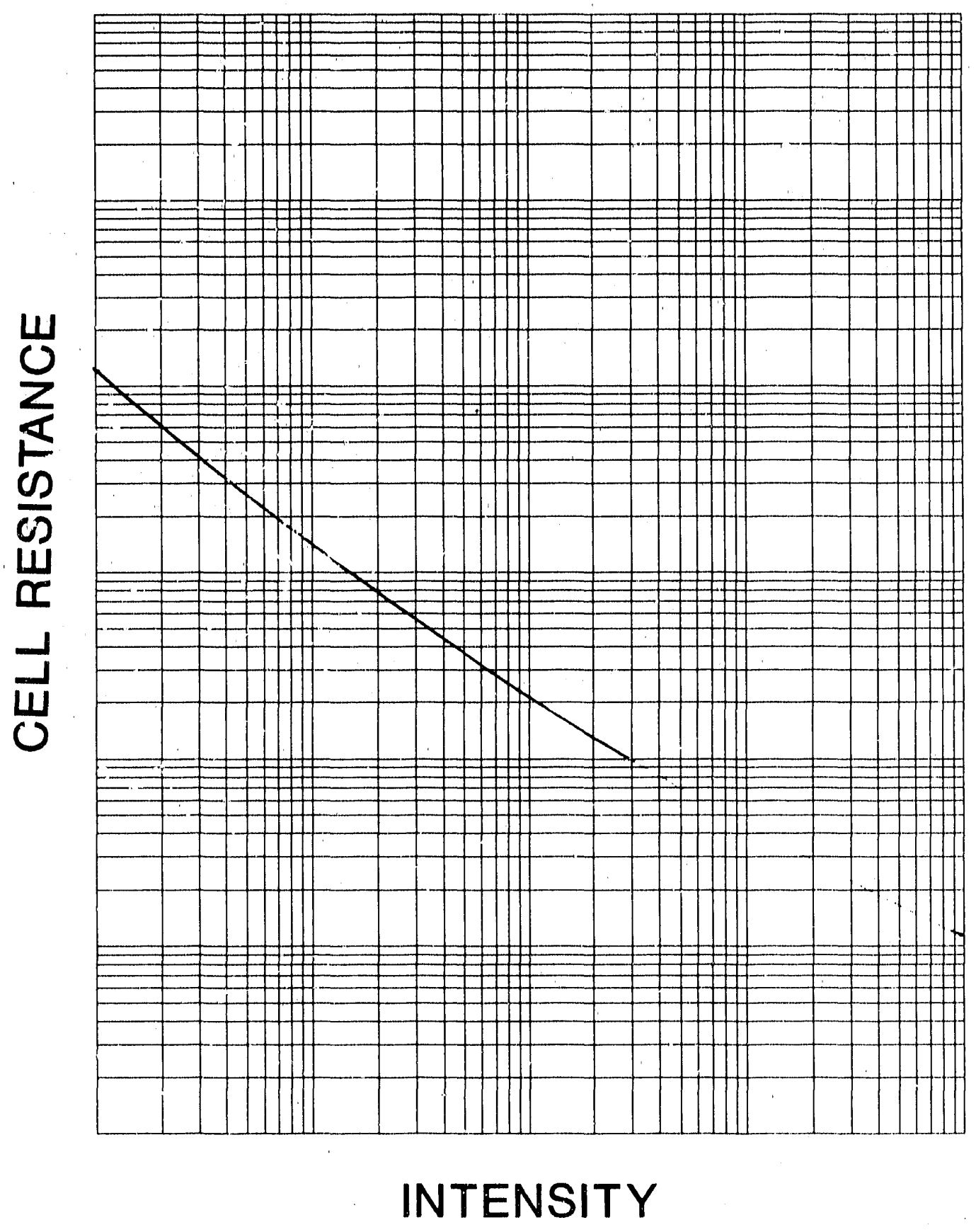

Figure 66. Illustration of the Relationship Between Light Intensity and Resistance of a Cad Cel1. 
sensor and the flame. A plastic filiex could be used with very roughly constant transmission over the visible and the cost would be insignificant.

In section 4 the use of the ratio of continuum (broad band) intensity to the intensity at the $\mathrm{OH}$ peak $(310 \mathrm{~nm})$ as a flame quality signal was discussed. The primary advantage of the use of this ratio, as opposed to simply the continuum intensity is reduced sensitivity to sensor surface fouling. Implementation of the measurement at the $\mathrm{OH}$ peak would require the addition of a narrow band pass filter. In addition, a sensor more sensitive than a photo-conductor would be required because of the reduced intensities generally in the ultraviolet range and the narrow wavelength involved. Narrow bandpass filters are available for this purpose. These are glass filters with depositions of selected nonconductive materials. The minimum cost involved would be about $\$ 10.00$. To achieve the required detector sensitivity a vacuum photodiode or (better) a photomultiplier could be used. Complete with high voltage power supply this would involve a minimum cost of $\$ 40.00$. Considering that the wholesale cost of a residential oil burner is less than $\$ 200$, it seems clear that the added cost required to measure the intensity at $310 \mathrm{~nm}$ would greatly reduce the attractiveness of the optical flame quality indicator. Some cost reduction could be realized using a semiconductor photodiode (GaAsP) and a filter with a broader band pass. A filtered sensor of this type is available (for example, from Hamamatsu Corp., Mode1 G3614) for about $\$ 14.00$. This would measure more than just the $\mathrm{OH}$ peak and an additional filter may be required.

Another approach discussed in section 4 involved the measurement of flame color. This could be achieved using two CdS photoconductors, each with a different broad band filter. This could be realized at very low cost, again using colored plastic filters. Unlike the narrow bandpass filter required for the measurements at $310 \mathrm{~nm}$ these transmit over a very broad range in the visible (several hundred $\mathrm{nm}$ ) and would add an insignificant cost.

In section 4 it was shown that flame quality sensors based on color are nost effective if the viewpoint is at the back end. This would involve several complicating factors. First, the optical sensor system could not be supplied integral with the burner but would have to be integrated with the complete boller/burner; system. In dry base, steel bollers, or other systems with an uncooled back wall, a penetration through the refractory wall and outer casing would be required. With cast-iron, section bollers or other boilers with water cooled rear walls a penetration through the pressure section would also be required, adding significantly to the cost. In addition, since the sensors are not located within the burner air tube, an additional fan for cooling and purging the sensors would be required. The mininum added cost for the $f$ an is estimated to be $\$ 5.00$. Generally the flame color approach appears reasonable from a cost perspective. Because it requires integration of the sensor with the boiler and burner, however, this approach would be most attractive on new, matched systems.

In section 4 it was shown that the broad band intensity of light as sensed by a CdS photoconductor located within the burner airtube could be a useful ineasure of flame quality. One circuit for implementing this is illustrated schematically in Figure 67. This provides three LED lights to 


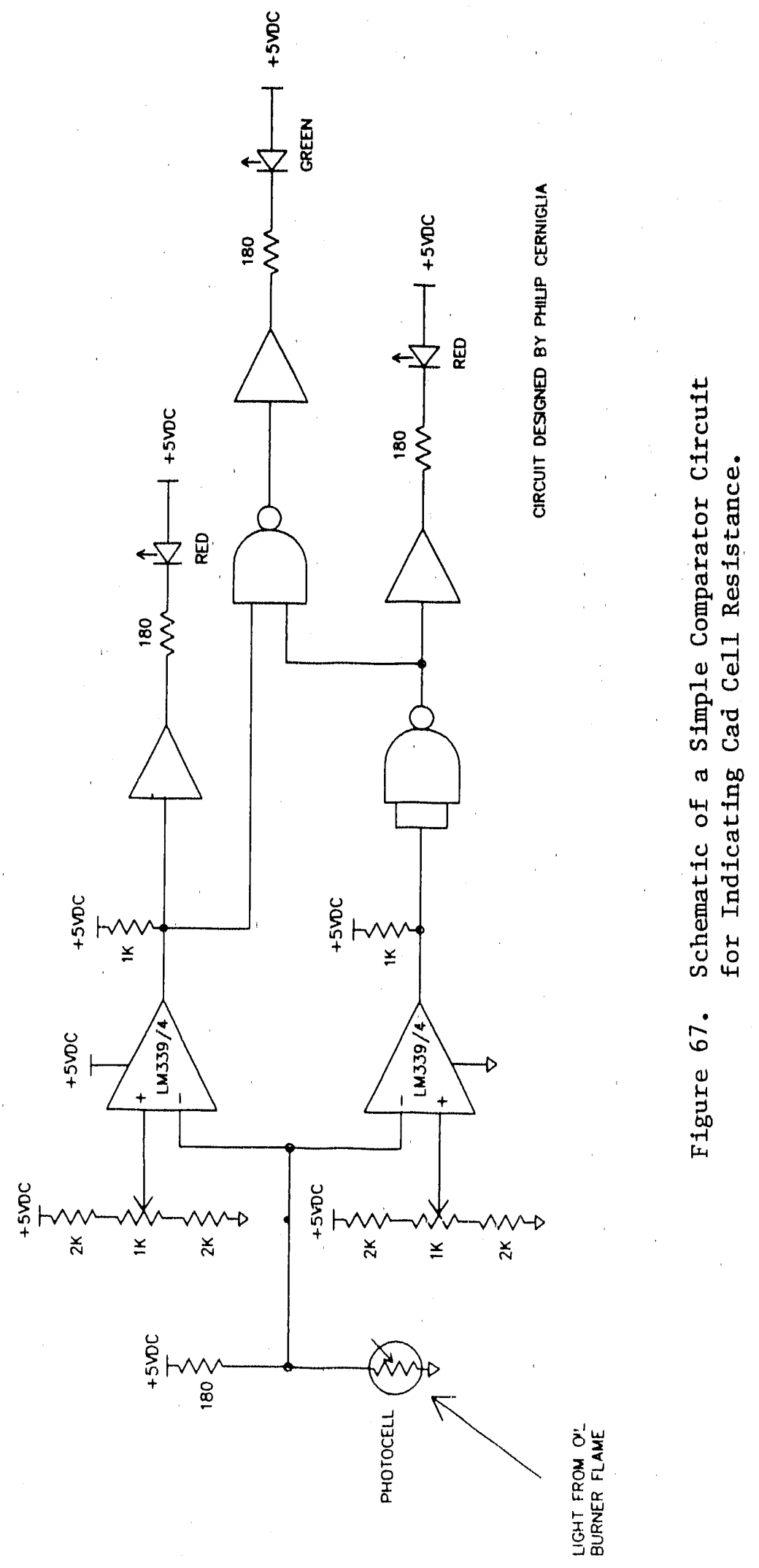


indicate the resistance of the CdS photoconductor. When the cell resistance is at the setpoint a green light comes on. Red lights indicate a high or low resistance. This circuit was assembled and tested during this project. Three integrated circuits were used including a quad comparator amplifier, a quad "NAND" gate and a quad LED driver. The total cost of the components is about $\$ 9.00$ including the CdS photocell but not including the $5 \mathrm{~V}$ DC power supply. In an actual installation the power supply might be adapted from the existing burner safety control. Otherwise, if a dedicated power supply were used, the added cost would be under $\$ 5.00$.

In a laboratory test this optical system was used to adjust the burner air/fuel ratio with a repeatability of about \pm 1 percent of excess air. In cyclic operation ( 5 uin on/15 min of $f$ ) the system operated reliably for a period of two months after which the test was stopped. It should be noted that longer term field tests are planned for the future.

One of the disadvantages of the simple broad band intensity signal is that the setpoint is dependent on the boiler or furnace into which it is fired. If the system were used in a burner intended for general use, the setpoint would have to be escablished as part of the installation procedure. The sensor system would then be useful in indicating when subsequent changes in flame quality and/or excess air occur. If, however, this optical system were used in new matched burner/boller unfts, a setpoint could be established by the manufacturer. The inttial excess air adfustment could then be easily done based on the lights.

Another potential disadvantage of the system 1llustrated in Figure 67 is that the system only indicates flame quality accurately when the burner is on and the combustion chamber is close to steady state. As discussed in section 4 of this report, the che uber warmup period is long in systems which have large refractory liners ill the combustion chamber. This situation could be improved by adding a sample-and-hold function in the circuit which would hold the lights in their condition at burner shut-down through the off cycle. This would enable the homeowner to "inspect" the burner condition at any time.

\subsection{Telephone Link for "Service Required"}

Over the last few years systems have become avallable which allow service companies to monitor home oll tank levels remotely. A low oll tank level is communicated through the existing telephone service to a central computer. Manufacturers of these systems include Scully Signal Company (Wilmington, MA) and STS Systems, Inc. (Canada). These systems are also currently capable of indicating when a burner control lockout has occurred and when the indoor alr temperature has dropped below a setpoint indicating a heating system failure.

The optical systems discussed in section 5.2 , or other service required signals as dis issed in section 4 could be integrated with these telephone link systems fairly easily, and at minimal additional cost. The current cost, however, of the telephone link systems will limit the penetration to the more affluent homeowner market. The cost of the base computer system at the service company is $\$ 2,000-\$ 3,000$. The cost of the equipment required at each 
hoine ranges $\$ 80-\$ 140$. While integration of the sensors discussed in this report with telephone link systems offers obvious advantages, the use of sersors with simple, local condition indicators may achieve greater market penetration, at least in the near term.

\subsection{Implementation of Active Excess Air Trim}

Much of the discussion in previous sections involved methods of indicating burner condition for service purposes. As an extension of this, oil burners which self-tune excess air based on selected control system inputs might be considered. Control systems of this type are commonly used in larger commercial and industrial bollers (see gection 2.1). Self-tuning, gas-fired residential heating units have also been bullt although there has been essentially no market penetration by these units to date.

For such control systems one or more inpits are required which indicate alr/fuel ratio and/or flame quality. For excess alr a zircontum oxide sensor 1s the most promising candidate. A very small sensor of this type (manufactured by Nederlandse Philips Bedrifven) has been used in a prototype selftuning gas burner developed by a Dutch Gas Research Group. It seems likely. that the quantity cost for sensors of this type, with heater controls, will be $\$ 40-\$ 80$.

To implement active excess alr control it i.s necessary to modulate either burner alr flow or oll flow. Wtth conventional pressure atomized nozzles ofl flow modulation could only be done by varying oil pressure. Currently, nozzles are rated at $100 \mathrm{ps} 1$ and 011 flow varies with the square root of this pressure. A reduction of oll pressure much below 100 psi would lead to larger drop sizes in the spray and increased smoke. Assuming a set point pressure of $144 \mathrm{psi}$ and maximum and minimum pressures of 200 and 100 psi, respectively, gives a control range of $\pm 18 \%$ on air/fuel ratio. Because of the high pressures involved and the limited control range, it seems more reasonable to consider alr modulation instead of ofl modulation.

In a conventional oil burner, air flow could be controlled either by throtting burner fan inlet air or by modulating the fan motor speed. For the firet approach a very small damper actuator would be required. Systems of this type are very common in larger boller controls and actuators may be either pneumatic or electrical. Damper actuators of this type are also conmonly used in warm alr heating systeme to provide zoning. Because current residentlal oil heating systems do not already have a supply of compressed alr avallable, electrically operated actuators would be more reasonable. These can be one of two basic types - proportional control actuators and directly operated. Proportional actuators would recelve an input signal from a control circult (e.g., 2-15 volts $\mathrm{dc}$ ) and would produce a proportional damper position. A directly operated actuator would move the damper at a fixed rate in response to an input signal which is elther on or off (or reverse). Cost estimates for these actuators range from $\$ 25$ to $\$ 50$. In any case, an added control circult would be required with an additional cost of about $\$ 15$.

In modern retention head burners, both the fuel pump and the combustion air fan are driven by single electric motor typlcally rated at $1 / 8-1 / 7$ 
horsepower. Combustion air flow could he controlled simply by modulation of this drive. The ofl pump discharge pressure is regulated by an adjustable back pressure relief valve integral with the pump creating an internal (or externa1) recirculation of the excess oll flow. Modulation of the motor speed over a limlted range would change only the rellef valve flow rate but not the pressure. Since the flow of ofl through the nozzle is driven by pressure, the burner firing rate would not change. Fuel pumps are commonly avallable which are rated for service at efther $1750 \mathrm{RPM}$, typlcal of older burner designs, or 3600 RPM, for currently made burners. A $2: 1$ range of motor speeds could then be used without changling fuel flow. Th1s would produce roughly a $2: 1$ range in burner alr flow.

Varlable speed motor drives are becoming increasingly popular for fan and pumping applications particularly in larger sizes ( $1 \mathrm{HP}$ and up). There is a considerable improvement in efficlency in using variable speed motors in place of throttling for flow control [31]. At $1 / 7$ horsepower an oil burner motor draws about 270 watts which is equivalent to $920 \mathrm{Btu} / \mathrm{hr}$. Assuming a factor of 3 for the power production, the primary ofl energy use due to the motor is $2800 \mathrm{Btu} / \mathrm{hr}$. For a burner with a firlng rate of $.5 \mathrm{gal} / \mathrm{hr}(72,000 \mathrm{Btu} / \mathrm{hr})$, the notor energy is $3.9 \%$ of the total consumption. For a typical air flow at 0.5 gph firing rate, the theoretical fan horsepower is small - less than .01 HP. Assuming even very poor fan efficiency ( $10 \%)$, the fan's contribution to the required motor horsepower is about $1 / 3$. The purpose of this discussion on power is to point out that the energy savings which might be realized by using a variable speed drive in place of throttling to control burner alr flow are sinall (under 1/2\%) and should not be considered as a primary factor in comparing alternatives.

011 burner motors are typlcally split phase (resistance start). These have auxillary windings which are powered from start to about $85 \%$ of the rated speed. These motors cannot be operated at variable speed. Continuous operation with the auxilary windings powered would lead to excessive current draw and notor fallure. A better option for variable speed operation would be a permanent split capacitor (PSC) motor in which the auxiliary windings are powered continuously. This type of motor is commonly used for small fan applications end can have its speed changed either with an adjustable frequency inverter or with varied input voltage. The primary disadvantage of the PSC motor is low starting torque. A split phase motor has a starting torque about equal to the full speed rated load torque while a PSC motor has a starting torque about half (or less) of the full speed torque. The high torque requitrement is imposed by the oil pump. The low starting torque disadvantage of the PSC motor could be overcome by using a two-value capacitor motor ("capacitor start - capacitor run"), although this is less common. As an alternative the ofl pump and combustion fan could be driven by separate notors, although this would require a substantial change in system design.

In the ofl heat industry, the use of induced draft, powered venting is starting to become accepted. In this case combustion air is driven both by a conventional burner fan and an added induced draft fan. Mcdest changes in excess air could be easily achleved in these systems by modulating only the draft inducers which are typically driven with a PSC motor. This would reduce the speed controller power requirements to about 100 watts and this could be inet with a simple triac controller. The cost of such a simple controller 
SENSOR TYPE

Photoconductors

$$
\begin{aligned}
& \text { CdS } \\
& \text { CdSe } \\
& \text { PbS } \\
& \text { PbSe }
\end{aligned}
$$

\section{Junction Detectors (Photodiodes)}

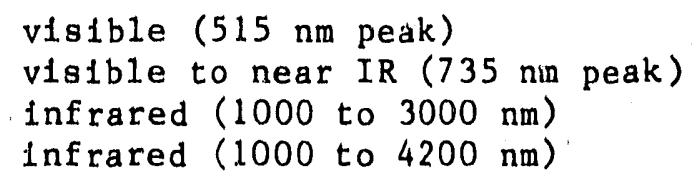

UV to near IR (about 200 to $1100 \mathrm{~nm}$ ) near IR (700 to $1900 \mathrm{~nm})$ UV to visible (190 to $760 \mathrm{~nm})$ UV to visible (190 to $520 \mathrm{~nm}$ ) infrared (1500 to $4000 \mathrm{~nm}$ )

Photoem1ss1ve Detectors

Vacuum Photodiode Photomultiplier

Thermal Detectors
UV to near IR

UV to near IR

UV to far IR 
would be about $\$ 15.00$. A potentlal disadvantage of controls of this type 1s that they tend to be fairly noisy.

For modulation of the speed of the combined burner o1f pump and combustion alr fan, another option is a brushless DC, electronically commutated motor (ECM) [32」. These long-11fe motors have high starting torque and are avallable in the required horsepower range. One advanced gas fired furnace uses an ECM to drive an induced draft fan and another to drive the furnace warm air blower [33]. These motors, with the required DC control electronics, are fairly expensive. For oll burner service the cost would likely be $\$ 50$ $\$ 100$. Using the ECM, the speed could be easily controlled over a wide range. In addition, a feedback motor speed signal could be readily provided by the ECM control circuit. This could be used in the overall burner control system. 


\section{DISCUSSION OF CONTROL STRA'EEIES}

Four spectifc control approaches are compared in this section with regard to cost, potential energy savings, and practical facturs. In each of the four cases assumptions are made about the components which might be used and the type cif output indications. Other options, however, could certainly be used. In no case, for example, is the use of a telephone link considered speciflcally. This is done only because 1 t would add substantial cost with the primary benefit being conventence and not substantial energy savings. In homes in which the telephone links are being used, these should certainly be considered for communicating information on the burner and heating unit condition. This technology holdo great promise for improving the efficlency of service organization operations and heating equipment reliablifty. In addition, future control sensors are likely to be integrated with heating system primary controls, effectively reducing costo. A resistance temperature detector integrated with the primary control could replace a peak hold dial thermoneter, for example.

\section{Stack Thermometer with Peak Hold}

For evaluating fouling of the heat exchanger, the peak cycle flue gas temperature is the simplest and most effective measurement parameter. The use of a dial type thermometer with a maximum indicating arm would enable the homeowner to monitor system efficiency changes over the heating season and schedule a cleaning when performance degrades. The wholesale cost of this thermometer is about $\$ 35$. The average annual efficiency degradation due to fouling is about $2 \%$ whlch corresponds to a rise in peak flue gas temperature of $650 \mathrm{~F}$. A stack thermometer would provide the greatest benefit in cases where a burner problem has occurred and the heat exchanger fouling rate $1 \mathrm{~s}$ unusually high. Another important application is those systems which are not cleaned on a regular basis. The stack thermometer would prompt the homeowner to arrange for a cleaning when he might otherwise let the system run in a degraded condition for years. Assuming a reduction in annual fuel use of $2 \%$ with cleanings indicated by stack temperature and an annual o11 bill of $\$ 800$, the simple payback would be 2.2 years. In some cases, however, particularly those in which burner problems do not develop over the heating season and which are cleaned properly on a regular basis, there would be no measurable benefit of a stack thermometer.

In the fall, as the load of a boller with a domestic coll changes from hot water only to hot water plus heating, a jump in the cycle peak reading should be expected. In the next level of complexity, thermocouples arranged to indicate the differential between the flue gas and the boller water temperature would be very useful. Such a system would reduce varlations over cycles and seasons.

Flame Quality Indicator Light

In the general case, flue-gas $C O$ measurements were not found to be useful indicators of smoke. Co levels become high only at very high smoke levels. A 
very important exception to this is the case of the prevapor-izing burner. For burners of thls type and blue-flame burners, CO often leads smoke and so could be a very useful control system input. For the prevaporizing burner tested, the output of the zirconium probe increased aignificantly at the point at which $\mathrm{CO}$ and smoke began to increase. This was a result of reduced flue-gas $\mathrm{O}_{2}$ as well as increased combustibles on the sensor surface. The use of zircontum sensoirs could be a very attractive control approach for high perforinance burners of this type.

The optical-emission measurements which were made during this study show that this approach may be very useful in providing a measure of the flame quality. The variation in continuum intenstty with smoke number could be very simply measured using, for example, the famlilar cad cell. The addition of a sensor to measure emissions in a narrow band about the $\mathrm{OH}$ peak in the UV and the use of the continuum/OH ratio for control offers a significant advantage. This dual sensor system would be much less sensitive to small shifts in sensor position, coke deposits on the burner t1p, and the buildup of dirt or oll film on the sensor. A disadvantage of the dual sensor approach 1s, of course, the additional cost.

The optical approach generally has the disadvantage of not beling totally independent of firing rate and nozzle characteristics and of being subject to possible blockage problems. As a service tool, however, the optical approach could be very useful. Service personnel could adjust excess air until a given intensity or intensity ratio is obtained and then simply check the steadystate smoke number and excess alr to ensure that the setting is reasonable. A substantial change in firling rate would require a setpoint change but the setpoint would not need to be changed if a slightly different spray pattern were used.

Based upon the simple comparator circult for the cad cell described in section 5, the cost of a local flame quality indicator will certainly be less than $\$ 20$. This system will save energy simply by triggering a burner service call before service efflciency degradation has occurred. Assuming a $2 \%$ annual savings, a simple payback period of 1.3 years results (again $\$ 800$ annual fuel bill assumed).' As in the case of the stack thermometer, an energy savings would be realized only in cases where burner problems develop between regular service. In light of this, it would be worthwhile to consider the relative frequency of occurrence of burner problems. In a recent oil heat industry workshop [34] participants were polled about the most significant service problems. Three 1tems made up $70 \%$ of their responses:

1. sooting

2. burner setup and service diagnostics

3. oll quality

Also a recent analysis of the oil heating service industry 1isted the quantities of replacement parts required for servicing exisling burners [35]. The most common are listed below: 


\begin{tabular}{lr} 
Item & Annual Usa \\
\cline { 2 - 2 } o11 f1lters & $7,972,540$ \\
nozzles & $7,775,573$ \\
controls & 762,063 \\
transformers & 500,845 \\
motors & 450,682 \\
circulators & 200,769
\end{tabular}

These two examples simply serve to point out the importance of fuel and nozzle related problems. Both the flame quality indicator and the stack thermometer are relevant to these problems.

In addition to the simple cad cell, the results in section 4 and the discussion in section 5 indicate that optical intensity ratios could also be used. The primary disadvantage of these is increased cost and the primary advantage is reduced sensitivity to sensor fouling. Based upon the data currently avallable, the simple cad cell approach appears to be most attractive. The long term rellablilty of this approach, however, has not been evaluated. If sensor fouling proves to be a serlous problem then further consideration should be given to the two color approach.

Local Oxygen Indicator

The addition of a zirconium oxlde oxygen sensor with local output would be a great ald in burner tuning and diagnostics. Continuous monitoring of oxygen would indicate when excess air has changed due to fouling of the burner air inlet, flue blockage, or other burner upset. As discussed in section 2, however, the oxygen sensor may not indicate that service is required, in the case of a fouled nozzle. In many cases, when a nozzle fouls the ofl flow rate drops (and flue gas oxygen increases), the spray pattern becomes skewed and the smoke level increases. A service required signal which is triggered by low flue gas oxygen would not indicate that this has occurred. At a cost of $\$ 50-\$ 100$ the oxygen sensor is expensive, and considering that it would be most useful as a service tool it is best carried by the serviceman rather than permanently installed on each boiler.

\section{Feedback Excess Air Trim}

One of the control modes under consideration in this profect is rutomatic excess air control. While elther optical or flue gas oxygen sensor inputs inight be considered, both have serious limitations. The difficulty with the oxygen probe, as discussed above, is related to the occurrence of a fouled nozile. An oxygen based control system would function to reduce excess air in the case of a fouled nozzle and so further increase snoke.

Similarly, a control system based on optical intensity could have serious problems in the case of partial blockage or fouling of the sensor. For example, a case could be considered in which a burner is adjusted to give constant continuum intensity at a sensor in the combustion tube. As that sensor gets dirty, the buiner would be adjusted for higher smoke numbers and greater emission intensity to compensate, an unacceptable result. 
For the automatic excess-air control mode, the potential difficulties of the oxygen system and the optical system could be largely eliminated by including both as inputs into the system. The air controller would then function to keep both signals within bounds or, if unable to do that, indicate "service required" and possibly lockout. Any system for automatic excess air control should be a "trim" system only, able to adjust air flow only within a limited range. This would prevent the system from operating under fuel-rich conditions and producing high levels of carbon monoxide.

For implementing excess air control in conventional oil fired systems, either a modulating damper or a variable speed drive could be considered. Because of the potential for mechanical failure with the damper, the variable speed motor would seem preferable. In either case, the addition of the oxygen sensor, optical sensor, controller, and actuator would add about $\$ 200$ to the cost of the burner. This at least doubles the burner cost. Potential energy savings with automatic excess air trim, as in other cases, are strongly dependent $u_{j}$ on the current service practice. If the burner would normally be adjusted for very high excess air, the savings with an automatic trim system could be about $6 \%$ (see section 1 ). In this case the payback period, based on an annual oil bill of $\$ 800$, would be 9.2 years. If, on the other hand, the burner was serviced properly and regularly, the energy, savings with automatic excess air trim could be negligible.

Summary

Four specific control approaches are listed below and compared with regard to cost and potential savings.

\begin{tabular}{|c|c|c|c|}
\hline Approaches & Cost & $\begin{array}{l}\text { Potential } \\
\text { Savings (\%) }\end{array}$ & Payback (Years) \\
\hline $\begin{array}{l}\text { 1. Peak Hold Dial } \\
\text { Type Thermometer }\end{array}$ & $\$ 35$ & 2 & 2.2 \\
\hline $\begin{array}{l}\text { 2. Optical Flame } \\
\text { Quality Monitor } \\
\text { (single sensor) }\end{array}$ & $\$ 20$ & 2 & 1.3 \\
\hline $\begin{array}{l}\text { 3. Optical Service } \\
\text { Tool }\end{array}$ & $\$ 20$ & 6 & 0.5 \\
\hline $\begin{array}{l}\text { 4. Automatic Feedback } \\
\text { Air Trim }\end{array}$ & $\$ 150$ & 6 & 4.2 \\
\hline
\end{tabular}




\section{CONCLUSIONS}

Based upon the work performed during this program the following conclusions can be made:

- Evaluation of the rate of performance degradation due to heat exchanger fouling can be done very simply using the peak flue gas temperature during heating season firing cycles.

- Zirconium oxide oxygen sensors work well in oll-fired residential equipment and would be a very attractive part of an advanced control system. Based on current technology likely sensor cost is estimated to be $\$ 50-\$ 75$.

- Measurement of flame optical emissions has been shown to be a very useful method of evaluating flame quality. Potentially this could be done using a low cost photoconductor sensor (e.g., a cad cell). Additional evaluation of the behavior of this type of sensor in extended service is needed.

- Measures of the intensity of the continuum emission ("flame brightness") were found to be fairly good indicators of flame quality in tests with a broad variety of nozzles. An intensity "setpoint" for excess air adjustment for a specific nozzle could be used without resetting if a nozzle with a moderately different firing rate or spray angle were substituted. The measure of the continuum intensity could be in a narrow wavelength band or it could be made over a very wide band using, for example, an unfiltered cadmium sulfide photoconductor (cad cell).

- A three light flame quality indicator, using a cad cell could be produced at a cost of about $\$ 20$ which would indicate "service required". Assuming an annual savings of $2 \%$ resulting from improved maintenance a simple payback of 1.3 years would result.

- An improvement over the simple continuum intensity measure of flame quaifty would be realized if the ratio of continuum intensity to the intensity at the $\mathrm{OH}$ peak $(310 \mathrm{~nm})$ were used. The primary advantage of the use of this ratio is reduced sensitivity to moderate misalignment and fouling of the sensor.

- As another approach flame "color" measurements could be made using two broad band sensors with different spectral response ranges. This type of measurement is particularly useful if made from a viewpoint at the rear of the combustion chamber. Such a measurement would be extremely difficult to implement in "wet base" boilers, requiring the addition of an air purged opening through the water passages. This approach should be considered in new designs.

- Three uses could be considered for oxygen or optical sensors including 1) service tools to make excess air adjustment easier and more accurate, 2) "service required" signals, and 3) active exces air trim. For the first and second application efther $\mathrm{O}_{2}$ or intensity 
inputs could be used. The oxygen sensor will require a different setpoint for each nozzle, firing rate and combustion chamber configuration. The optical method may also require setpoint readjustment with substantial changes in firing conditions or with different combustion chambers. With either control input, a final check of smoke number and possibly small excess air readjustments in the field is still recommended.

- In the active excess air control mode situations could occur in which the control system creates a high smoke situation with either optical or oxygen input. This negative situation could be improved by using both oxygen and optical inputs and by limiting the controllable range for excess air.

- The cost of implementing active excess air trim is about $\$ 200$. A substantial energy savings would be realized in those cases in which burners are not properly serviced. 


\section{RECOMMENDATIONS FOR FUTURE CONTROL SYSTEMS}

\subsection{Techntcal Recommendations}

In this project a number of varied control inputs and approaches were consiclered. The results could be used in control systems which range from very simple with immediate application to sophisticated systems for the future. In this section recommended concepts for near term and far term controls are discussed.

The simplest case is the use of the flue gas cycle peak temperature to monitor degradation of the heat exchanger thermal performance. Dial type thermometers with a peak indicating arm are currently available. As a simplification of this a "dirty heat exchanger" warning light could be used to clearly indicate to the homeowner that a predetermined rise in flue gas exit temperature has occurred. The next step in the implementation of either of these approaches is the collection of data in a number of actual operating boilers and furnaces over a heating season. This would serve to demonstrate sensitivity and identify any practical factors which would influence selection of measurement methods and/or temperature sensor location.

The next level of complexity which should he considered is the optical flame quality indicator with local, three light output, as developed during this project. A major question remaining with this attractive optical approach is reliability over extended use. Long-term performance evaluation and, if required, optimization of the sensor location within the burner air tube to minimize fouling effects are specifically recommended. If the reliability of the simple optical sensor approach is not found to be acceptable, then dual wavelength sensors should be considered. This should include both the continuum to $\mathrm{OH}$ ratio and two broad band sensors (flame color). The latter approach should use a viewpoint at the back of the flame.

The simple optical system could be considered for refit to existing burners. In this case it would be very useful for indicating changes in flame condition after the burner has been properly adjusted by the service personnel. As a tool for adjusting the air/fuel ratio of a burner during initial installation and servicing, any of the optical approaches discussed in this report could be considered. The best application for this purpose, however, is in new, inatched systems. This would be a boller or furnace designed to operate with only ont brand of burner, at a fixed firing rate, with a specified nozzle. Under such a carefully controlled situation, a single control setpoint could be established, greatly improving the accuracy and simplicity of installation and routine service.

The next approach which should be considered is control systems which actively adjust burner excess air for optimal performance. The primary advantage of considering the "three light" (or related approach) system before the active control system is that it is essentially failsafe. A failure of the three light system might produce an unnecessary service call or, in the worst case, would simply not indicate a burner which needs service. This latter case is essentially equivalent to the present uncontrolled situation. The active control system, however, could create an alr fuel ratio which is too 
lean or, worse, too rich. For this reason implementation of active controls should be considered after the rellability of the sensors has been established. A system which actively trims excess air has some very significant advantages and should be considered as the eventual goal of controls development, in spite of the presently estimated costs for such systems. Such a system would make service very simple and accurate. In addition, it would permit variation in excess air over the firing cycle to reduce transient smoke and ensure that the equipment operated at maximum efficiency over the entire heating season. For maximum reliability both oxygen and optical sensors should be used in active control systems.

\subsection{Programmatic Recommendations}

The use of advanced control systems would lead to maintaining a higher level of efficiency and reliability of ofl fired home heating systems than would result by current practices of service personnel. The following two planned follow-on activities will help the commercialization by establishing reliability under realistic field conditions and by evaluating market potential.

\section{Field Tests on the Optical Flame Quality Indicator}

Testing is continuing to evaluate the reliability of the three light optical flame quality indicator under actual field conditions.

\section{Evaluation of Market Potential}

A presentation and brief report describing the optical flame quality indicator will be prepared for discussions with industry groups. Based on discussions with controls manufacturers, primary equipment manufacturers, and service organizations the level of commercial interest as well as any concerns will be identified. The physical configurations for this concept which are most interesting commercially will also be identifled. 


\section{REFERENCES}

1. T. Butcher, Y. Celebi and M. Piraino, "Evaluation of the Low Temperature Heat Exchanger Fouling Problem," BNL Report 51810, June 1984.

2. G. E. Kelly, D. A. Didion, D. Quigley and B. Collins, "Potential Energy Savings in Residential 011 Fired Heating systems in the U.S.," NBS Building Science Series 163, National Bureau of Standards, 1984.

3. M. Hopkins, "Applying the Best Technology to Assist Low-Income Households: 011heat Retrofit Program," Proceedings of the 1989011 Heat Technology Conference and Workshop, BNL 52217, June 1989.

4. "Development of a Test Set for Adjustinent of Residential Furnaces and Bollers," report prepared by Honeywe11, Inc. for Brookhaven National Laboratory, Report Number BNL-51239, 1980.

5. M. Ohsuga and Y. Ohyama, "A Study on the Oxygen Blased Wide Range Air Fuel Ratio Sensor For Rich and Lean Atr Fuel Rat1os," Sensors and Actuators, Vol. 9, 1986.

6. F. J. Rohr, H. Hollck, A. Minor, and A. Rente1, "Exhaust Sensors for Heating Systems," BMFT-FB-T 80-054 (German Govt. Report), 1982.

7. A. P. Bergman and C. Franx, "Microelectronics In Future Gas Appllances," 1984 International Gas Research Conference, Washington D.C., Sept. 10-13, 1984 .

8. C. Franx, "ZrO2 Oxygen Sensor," Electrontc Components and Applications, Vol. 7, No. 4, pp. 217-221.

9. C. Franx, "A Dynamic Oxygen Sensor with Zero Temperature Coefficient," Sensors and Actuators, Vol. 7, pp. 263-270, 1985.

10. A. Jones, P. Moseley, and B. Tofleld, "The Chemistry of Solld State Gas Sensors," Chemistry in Britain, pp. 740-766, Aug. 1987.

11. K. Ihokura, K. Tanaka, and N. Murakami, "Use of Tin Dioxide Sensor to Control a Domestic Gas Heater," Sensors and Actuators, Vo1. 4, pp. $607-612,1983$.

12. T. Butcher, F. McNe11, Y. Celebl and J. Wegrzyn, "Impart of Burner Design Features on Sooting in Residential 011 Fired Systems," BNL Report 52102, November 1986.

13. "Development of a Test Set for Adjustment of Residential Furnaces and Bollers," report prepared by Honeywe11, Inc. for Brookhaven National Laboratory, Report Number BNL-51239, 1980.

14. R. H. Torborg and J. E. Janssen, "Performance and Radiation Studles with the API Prototype Blue-Flame Burner," API Research Conference on Distillate Fuel Combustion, Chicago, I111nols, June 13-15, 1966. 
15. J. M. Beer, "Radiation from Flames In Furnaces," in Combustion Technology - Some Modern Developments, H. B. Palmer and J. M. Beer eds., Academic, 1974.

16. A. Smith, J. Swithenbank, and D. Taylor, "Fuel: Alr Ratio Control Using Infra-red Spectroscopy," J. Inat. Fue1, June 1975.

17. J. M. Harfoot, "Combustion Control System for Industrial Package Bollers Using the Flame Radiation Peak Seeking Technique," New Ways to Save Energy: Proceedings of the International Seminar Held in Brussels, Oct. 23-25, 1979. D. Reldel Publishing Co., Holland, 1980.

18. M. J. Beer, M. T. Jacques, and J. D. Teare, "Individual Burner Fuei/Alr Ratio Control by Optical Adaptive Feedback Control System," M.I.T. Report No. EL-82-001, Jan. 1982.

19. C. I. Metcalfe, W. E. Cole, F. W. Fralm, and S. K. Batre, "Spectral Flame Analyzer for Burner Control In Fossil Fuel Bollers," EPRI Report Number CS-4844, Nov. 1986.

20. C. I. Metcalfe and W. E. Cole, "Development of Spectral Flame Analyzer for Individual Burner Control tn Bollers," U.S. DOE Report VOE/ID/12463-2, Nov. 1987.

21. "Flame Qual1ty Analyzer for Teinperature Measurement and Combustion Control," Sensors pp. 23-28, July 1988.

22. H. Hiroshi and Y. Oyama, "Air Fuel Rat1o Detecting Sensor," U.S. Patent $4,779,455$, Oct. 1988 .

23. M.F. Zabielsk1, C.J. Egolf, and H.H. Hollick, "IR Fuel/Air Control for Methane Combustors", GRI-88/0247, May, 1988.

24. C.F. Marlano, "A Low Input, Variable Firing Rate O11 Fired Burner," BNL 51558 , May 1982.

25. B. Brengdah1, Residential 0il Heating Trends in Europe and Recent Burner Equipinent Advancements, Proceedings of the 1987 0:1 Heat T'echnology Conference and Workshop, BNL 52148, Jan. 1988.

26. R. Babington, Introduction of a New High Efficiency 011 Burner With Varlable Firing Rate and Low Capacity Capabilities, Proceedings of the 1987 01.1 Heat Technology Conference and Workshop, BNL 52148, Jan. 1988.

27. D.W. Lock11n and H.R. Hazard (Battelle), Technology for the Development of High Efficiency Oil Fired Residential Heating Equipment, IBNL 5.1325, June 1980 .

28. Personal Communication, R. Levitt, Amperex Electronfes Corp., 1987.

29. J. Chedalile and $Y$. Braud, Industrial Flames-Vol. 1 Measurcments in Flames, ïnternational Flame Research Foundation, Edward Arnold Ltdn, London, 1972. 
30. J. A. Wlebelt, Englneering Radlation Heat Transfer, Holt, Rinehart and Winston, New York, 1966.

31. J. Andreas, Energy Efflclent Electrlc Motors, Marcel Dekker. Inc., New York, 1982.

32. N. Mohan and J. W. Ramsey, "Comparative Study of Adfustable Drives for Heat Pumps," Electric Power Research Institute Report (EPRI) EM-4704, 1986.

33. "The Plug 901: Intelligent Heating Machine," Alr Conditioning Heating and Refrigeration News, p. 39, Oct. 26, 1987.

34. R. MCDonald, Proceeding of the 1989 011 Heat Technology Conference and Workshop," BNL 52217, June, 1989.

35. M. Mantho, "Service Departments Turn Smal1 Profit," Fue1 011 and 011 Heat, pp. 31-36, May 1988. 

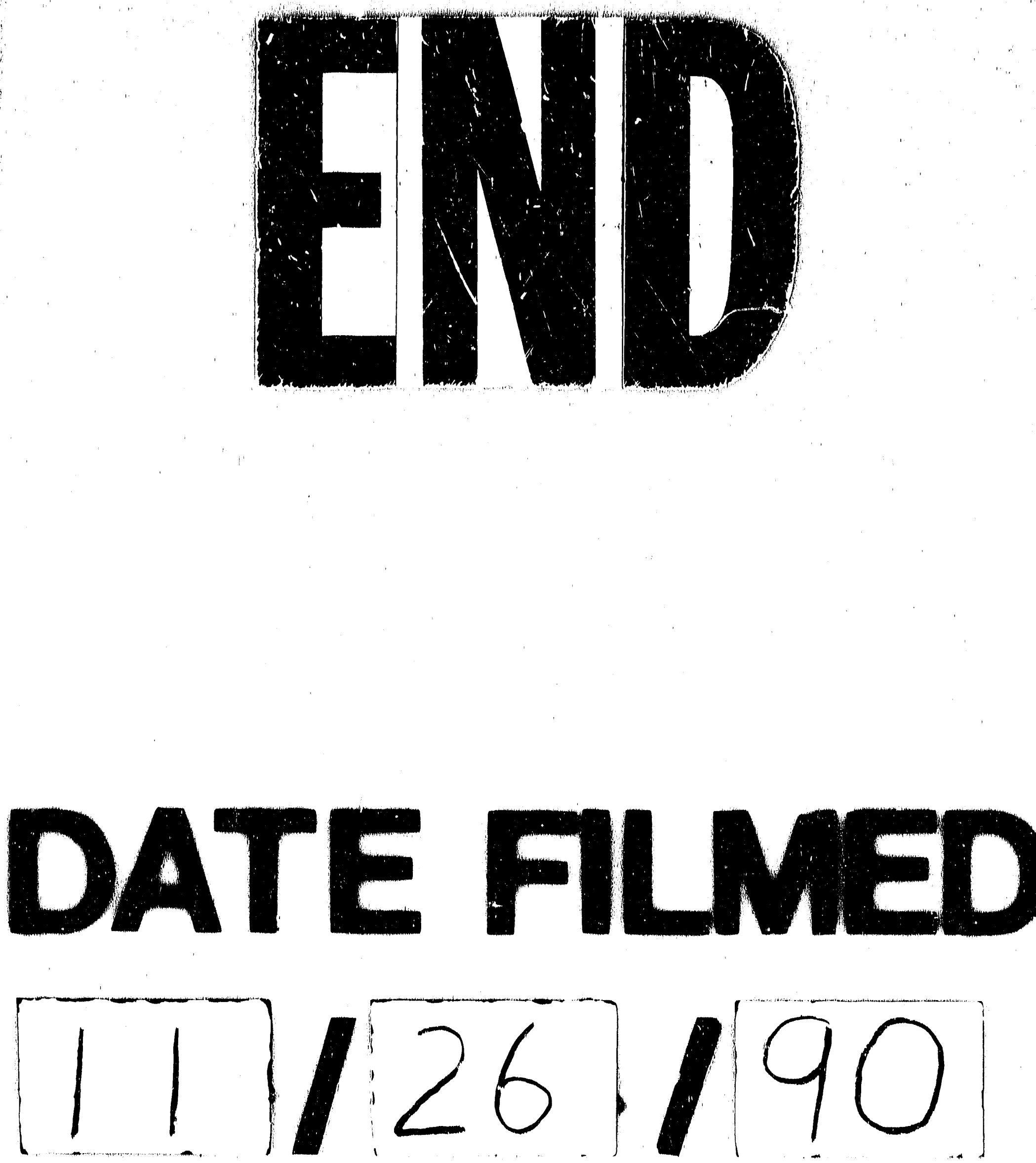
